\title{
Characterization and classification of clayey soils forming on limestone in the Eastern Panhandle of West Virginia
}

Brian Cooley

West Virginia University

Follow this and additional works at: https://researchrepository.wvu.edu/etd

\section{Recommended Citation}

Cooley, Brian, "Characterization and classification of clayey soils forming on limestone in the Eastern Panhandle of West Virginia" (2009). Graduate Theses, Dissertations, and Problem Reports. 2750. https://researchrepository.wvu.edu/etd/2750

This Thesis is protected by copyright and/or related rights. It has been brought to you by the The Research Repository @ WVU with permission from the rights-holder(s). You are free to use this Thesis in any way that is permitted by the copyright and related rights legislation that applies to your use. For other uses you must obtain permission from the rights-holder(s) directly, unless additional rights are indicated by a Creative Commons license in the record and/ or on the work itself. This Thesis has been accepted for inclusion in WVU Graduate Theses, Dissertations, and Problem Reports collection by an authorized administrator of The Research Repository @ WVU. For more information, please contact researchrepository@mail.wvu.edu. 
Characterization and Classification of Clayey Soils Forming on Limestone in the Eastern Panhandle of West Virginia

\title{
Brian Cooley
}

Thesis submitted to

The Davis College of Agriculture, Forestry and Consumer Sciences at West Virginia University in partial fulfillment of the requirements

for the degree of

\author{
Master of Science \\ in \\ Plant and Soil Sciences
}

John C. Sencindiver, Ph.D., Chair

Jeffrey G. Skousen, Ph.D.

J. Steven Kite, Ph.D

Division of Plant and Soil Sciences

Morgantown, West Virginia

2009

Keywords: shrink-swell; vertic; slickensides; cracking; soil classification 


\section{Abstract \\ Characterization and Classification of Clayey Soils Forming on Limestone in the Eastern Panhandle of West Virginia \\ Brian Cooley}

High shrink-swell potential soils forming from limestone have been noted in the Great Valley of West Virginia, but the taxonomic name of these soils does not indicate this potential. With increased pressures on land use from an increasing population in the Eastern Panhandle, it is necessary to have detailed soil information for soil scientists, county planners, engineers, and others. The objectives of this research were to characterize three soils forming on limestone, evaluate their shrink-swell potential, and classify these soils. Field observations and laboratory data indicate that Carbo and Swanpond soils have a high shrink-swell potential, whereas Hagerstown soils do not. High shrink-swell is recognized in the current classification of Swanpond soils (revised January 2000) but not Carbo soils. It is recommended that the classification of Carbo soils be updated to recognize this high shrink-swell potential. 


\section{Dedication}

This work is dedicated to my mother, Linda Cooley, my grandmother, Marie Crawford, and to the memory of my father, Dwight Cooley, my grandfather, Bill Crawford, and my grandparents, Tersey and Paul Cooley. 


\section{Acknowledgements}

First and foremost I would like to extend a special thank you to Dr. John Sencindiver. I am forever indebted to you for the patience and support that you have given during this endeavor. I feel very fortunate to have had you for an advisor and for the opportunity to work on this study. I am grateful for your willingness to remain as chairperson on this thesis and see me to completion even upon your recent retirement from West Virginia University. I feel that I have grown not only professionally but, also as a person from the examples that you have set and your guidance. Thank you, those two simple words can not begin to show the gratitude that I have for all that you have done for me.

I offer a sincere thank you to Dr. Jeff Skousen and Dr. Steve Kite for serving on my committee and for the suggestions and advice that you both have provided during this research study.

I would also like to thank several Natural Resource Conservation Service employees who were instrumental in this study. A big thank you goes out to Skip Bell for your help locating sites, assisting with the field descriptions and sampling, and sharing your knowledge of the soils in the area. Thank you to Steve Carpenter for your assistance with getting samples analyzed at the National Soil Survey Laboratory and Jared Beard for your insight and ideas about the soils and processes occurring in the study area.

Thank you to Denzil Blosser, Joan Wright and Jim Gorman for your help and assistance in the laboratory. Whenever I needed help with equipment, procedures or chemicals you were always willing to lend a hand. Although to numerous to mention individually, a special thanks to all the student workers who assisted me with field and laboratory work.

And finally to my family and friends, thanks for all the support and encouragement. To my mom, Linda Cooley, my grandmother, Marie Crawford, and Christina Reed, you are the most important women in my life. I have truly been blessed to have each of you in my life. Mom, you have provided me so much inspiration through your hard work and perseverance through life's adversities. Through good and bad times, you have always been that person that has been there for me. I can never thank you enough for the values and respect that you have taught and the love that you have shown. I would not be where I am today without you. Grandma, your unselfish acts, support, and love have been tremendous over the years. I am very thankful to have a grandmother like you. Christina, thank you does not seem to be enough for the love, support, and encouragement that you have freely given the past several years. You have brought a smile to my face more than once and your willingness to help in anyway possible has been appreciated these last few months. 


\section{Table of Contents}

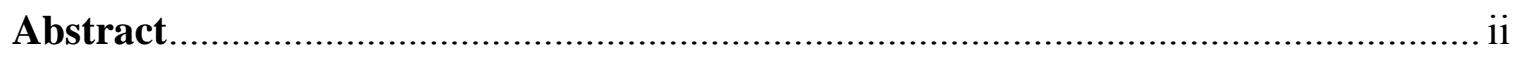

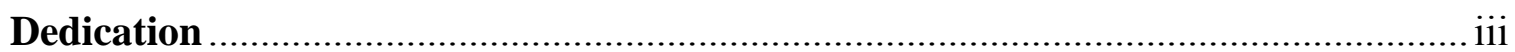

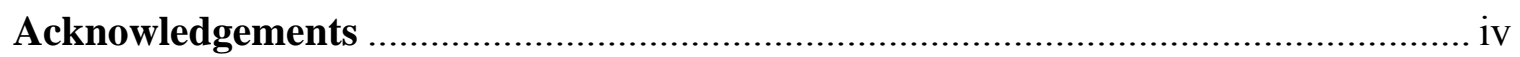

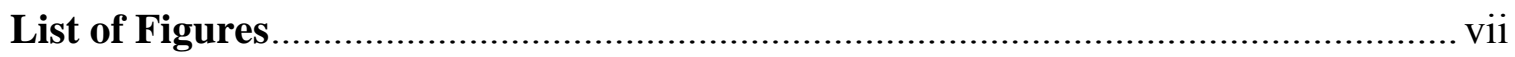

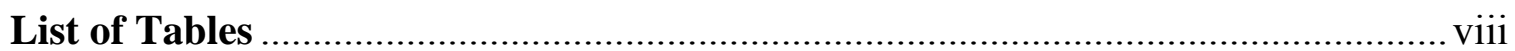

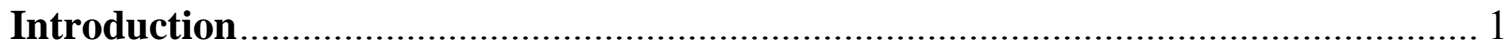

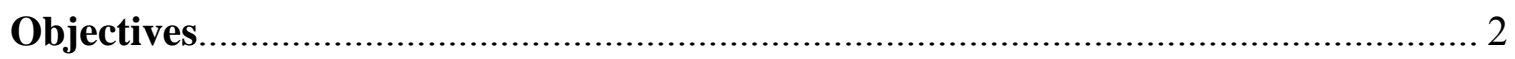

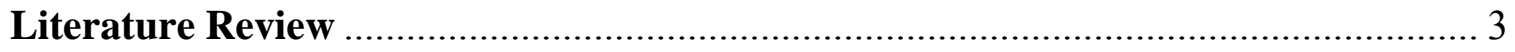

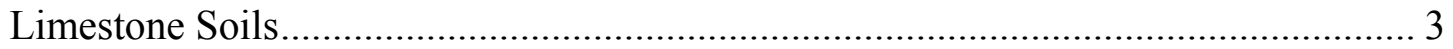

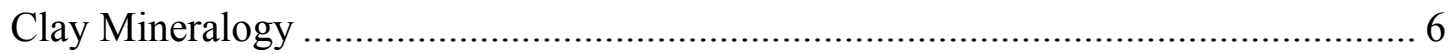

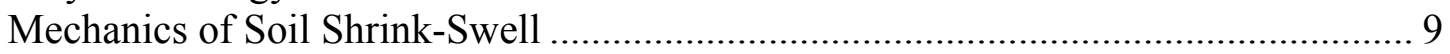

Measuring and Predicting Soil Shrink-Swell......................................................... 11

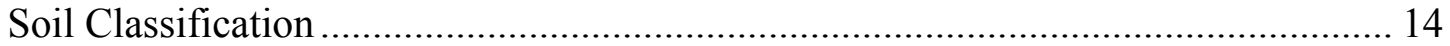

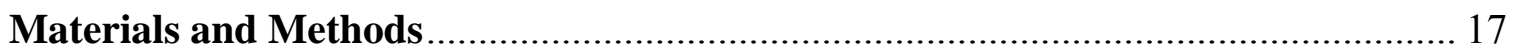

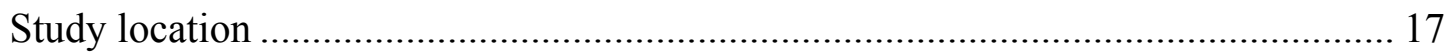

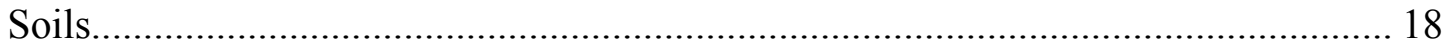

Geology

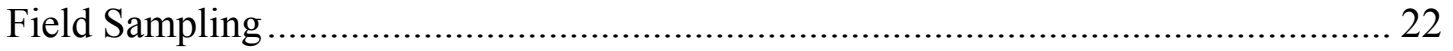

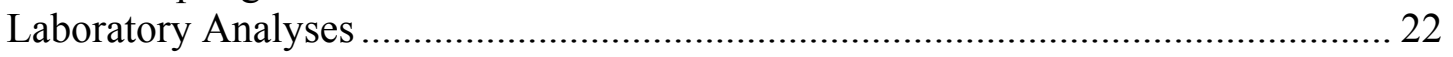

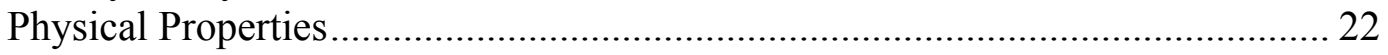

Chemical Properties ............................................................................... 25

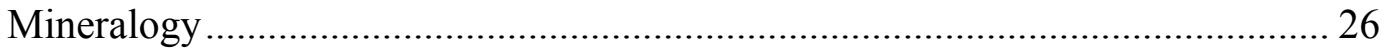

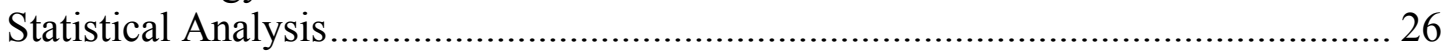

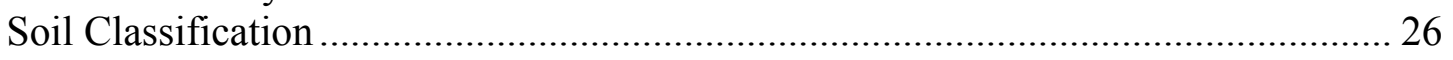

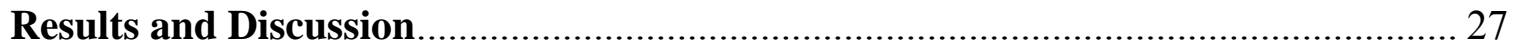

Field Observations of Slickensides and Cracking ………………………............... 27

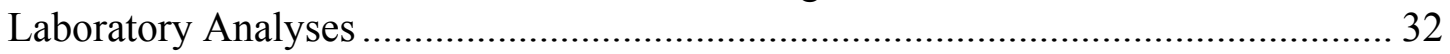

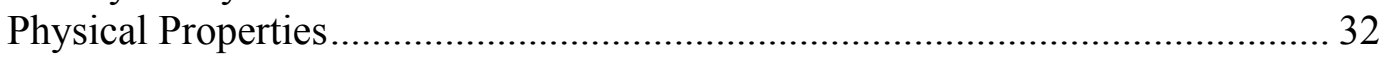

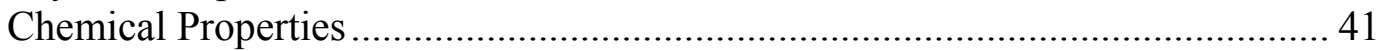

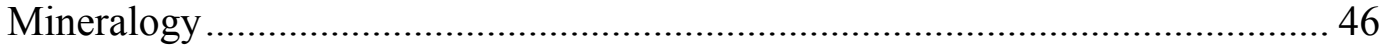

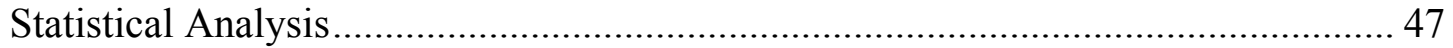

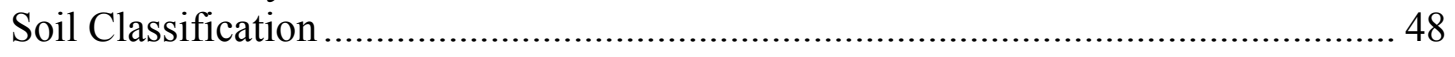

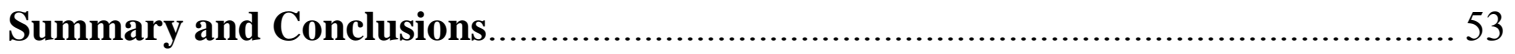


References.

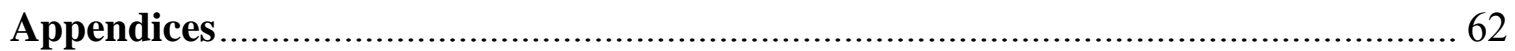

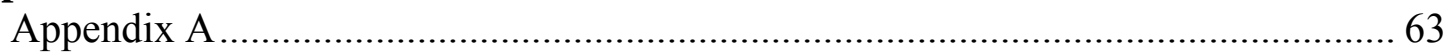

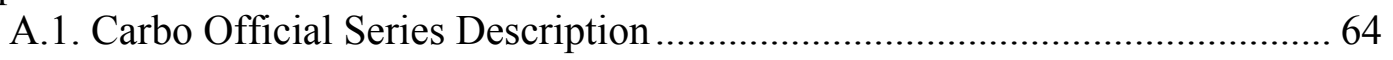

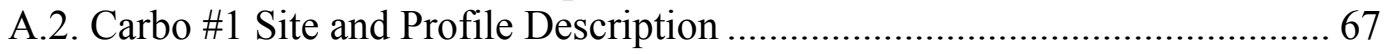

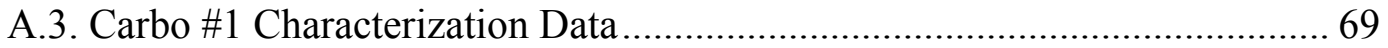

A.4. Carbo \#2 Site and Profile Description ....................................................... 71

A.5. Carbo \#2 Characterization Data ................................................................ 72

A.6. Carbo \#3 Site and Profile Description .......................................................... 74

A.7. Carbo \#3 Characterization Data.............................................................. 75

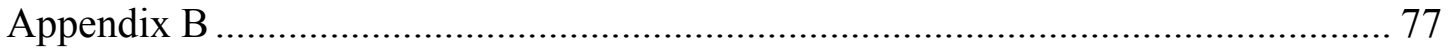

B.1. Swanpond Official Series Description ........................................................ 78

B.2. Swanpond \#1 Site and Profile Description ................................................ 81

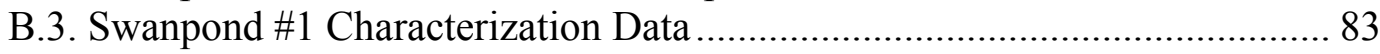

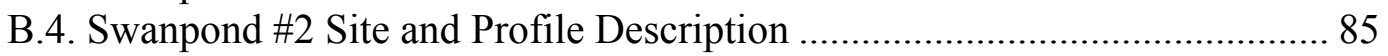

B.5. Swanpond \#2 Characterization Data ........................................................... 87

B.6. Swanpond \#3 Site and Profile Description .................................................. 89

B.7. Swanpond \#3 Characterization Data ......................................................... 91

B.8. Swanpond \#4 Site and Profile Description ..................................................... 94

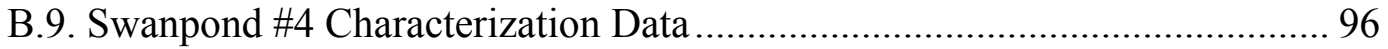

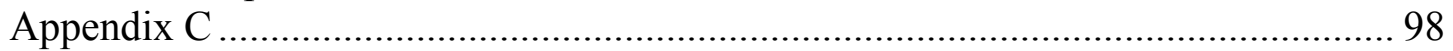

C.1. Hagerstown Official Series Description...................................................... 99

C.2. Hagerstown \#1 Site and Profile Description ................................................ 102

C.3. Hagerstown \#1 Characterization Data........................................................ 104

C.4. Hagerstown \#2 Site and Profile Description ................................................ 107

C.5. Hagerstown \#2 Characterization Data........................................................ 109

C.6. Hagerstown \#3 Site and Profile Description .................................................. 112

C.7. Hagerstown \#3 Characterization Data............................................................. 113 


\section{List of Figures}

Figure 1. Location of study area and sampling points............................................... 23

Figure 2. Surface cracking in Carbo soil in Berkeley County.......................................... 27

Figure 3. A large crack extending from the surface to bedrock in the Carbo \#1 pedon... 29

Figure 4. A large slickenside in the Carbo \#2 pedon................................................... 30

Figure 5. Intersecting slickensides in the Swanpond \#3 pedon. Quarters are used to show

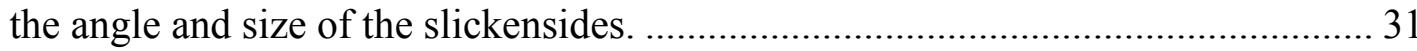

Figure 6. Distribution of $33 \mathrm{kPa}$ bulk density values for clayey soils............................. 34

Figure 7. Distribution of oven-dry bulk density values for clayey soils........................... 35

Figure 8. Distribution of COLE values for clayey soils. ............................................... 36

Figure 9. Distribution of clay content for clayey soils................................................. 37

Figure 10. Distribution of $33 \mathrm{kPa}$ moisture retention percentages for clayey soils.......... 38

Figure 11. Distribution of $1500 \mathrm{kPa}$ moisture retention percentages for clayey soils...... 38

Figure 12. Distribution of water retention difference values for clayey soils. ................. 39

Figure 13. Distribution of liquid limit values for clayey soils.......................................... 40

Figure 14. Distribution of plasticity index values for clayey soils................................. 41

Figure 15. Distribution of $\mathrm{pH}$ (1:1 water) for clayey soils. ............................................ 42

Figure 16. Distribution of $\mathrm{pH}$ (1:2 calcium chloride) for clayey soils............................ 42

Figure 17. Distribution of extractable acidity for clayey soils......................................... 43

Figure 18. Distribution of sum of extractable bases for clayey soils............................... 44

Figure 19. Distribution of CEC determined by the ammonium acetate method for clayey

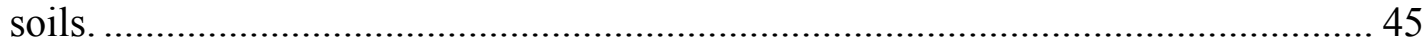

Figure 20. Distribution of CEC determined by summation of cations for clayey soils.... 45 


\section{List of Tables}

Table 1. Geology and selected field observations of each pedon............................... 28

Table 2. Number of observations (shown in parentheses) and standard deviation of soil horizon properties displayed in Figures 2 - 16................................................ 33

Table 3. Minerals present in the clay-sized fraction of each pedon............................... 46

Table 4. Duncan's Multiple Range Tests used to group similar soils based on weighted averages (shown in parentheses) of selected soil properties............................... 47

Table 5. Regression relationships between clay, coefficient of linear extensibility (COLE), and plasticity index (PI) and selected soil properties for clayey soils...... 48

Table 6. Soil Taxonomy classification for each pedon............................................ 49

Table 7. Acreages of soils with shrink-swell potential in the Great Valley of West Virginia and nearby areas. 


\section{Introduction}

In the Great Valley of the Eastern Panhandle of West Virginia soils form predominately from shale and limestone parent materials. Those forming on limestone are generally clayey and may have a high shrink-swell potential. Therefore, they may cause problems in foundations, roads and other engineering structures. These problems, widespread in areas of clayey soil, are commonly found in Vertisols of arid and semi-arid areas (Soil Survey Staff, 1999), but also have been identified in clayey Alfisols and Ultisols of humid areas. A study in Virginia by Thomas (1998) showed that soils with a high shrink-swell potential occurred in the southern portion of the Great Valley as well as other areas in Virginia.

Local residents of the Eastern Panhandle and soil scientists have noted properties of high shrink-swell potential in some soils. However, these soils, with the exception of the Swanpond series, are not currently classified as any taxon of soils having properties related to high shrink-swell. At the onset of this research, the Swanpond series was not classified as having properties related to high shrink-swell. It was reclassified in January of 2000 .

Field trips to the area have confirmed the presence of slickensides and cracks in the soils that appear to be related to high shrink-swell. It is not understood how, why or how widely these may occur.

Local soil scientists have expressed concerns about the classification of soils that may contain these apparent high shrink-swell properties because of the effects of these properties on land use. The Eastern Panhandle of West Virginia is one of the fastest growing regions in the state, resulting in an increased need for accurate soil interpretations. Berkeley and Jefferson counties ranked number one and two respectively in percent population growth from 2000 to 2007 in West Virginia. Berkeley County’s population grew by 31.4 percent, while Jefferson County's population grew by 20.5 percent (U.S. Census Bureau, 2008a). Berkeley County is listed as one of the top 100 fastest growing counties in the United States ranking $73^{\text {rd }}$ by percent population growth from 2000 to 2007 (U.S. Census Bureau, 2008b). It is important to have detailed soil 
information available to soil scientists, county planners, engineers and others because of these increased pressures on land use.

Updating of the Berkeley County Soil Survey by the Natural Resources

Conservation Service (NRCS) was ongoing when this research project was initiated.

Even though properties related to high shrink-swell have been noted in the area, there are currently no data to document their presence. Therefore, this research was initiated to investigate and document these apparent high shrink-swell properties.

\section{Objectives}

The specific objectives of this research were to:

1. characterize selected soils forming on limestone,

2. evaluate shrink-swell potential of the characterized soils, and

3. classify these soils. 


\section{Literature Review}

\section{Limestone Soils}

Soils forming over carbonate parent materials are commonly clayey in texture and red in color. Subsoil properties may be directly related to the parent material from which the soil has developed. Limestone soils form from limestone parent material that is calcitic, dolomitic or a combination of both.

Limestones are generally sedimentary in origin constituting about 10 percent of all sedimentary rocks by volume (Renton, 1994). "Limestone is a sedimentary rock consisting mostly of calcium carbonate, primarily in the form of calcite, and with or without magnesium carbonate, more specifically containing more than 95 percent calcite and less than 5 percent dolomite" (Jackson, 1997). The unstable mineral aragonite, which weathers easily into calcite, is also a common constituent of limestone (McCue et al., 1939).

Jackson (1997) defines dolomitic limestone, previously referred to as magnesian limestone, as "a limestone in which the mineral dolomite is conspicuous, but calcite is more abundant, more specifically containing 10 to 50 percent dolomite and 50 to 90 percent calcite having an approximate magnesium-carbonate equivalent of 4.4 to 22.7 percent or a $\mathrm{Ca} / \mathrm{Mg}$ ratio range from 4.74 to $60 . ”$

In order to be classified as pure dolomite, dolomitic limestones must contain at least 45.65 percent $\mathrm{MgCO}_{3}$ (McCue et al., 1939). Dolomite can be found in limestones of various ages and is formed by the sedimentation process or later by the substitution of magnesium for calcium (Emmons et al., 1960). Dolomite is defined by Jackson (1997) as "a carbonate sedimentary rock of which more than 50 percent by weight or by areal percentages under the microscope consists of the mineral dolomite, or a variety of limestone, or marble, rich in magnesium carbonate, more specifically a carbonate sedimentary rock containing more than 90 percent dolomite and less than 10 percent calcite, or one having a $\mathrm{Ca} / \mathrm{Mg}$ ratio in the range of 1.5 to 1.7 , or one having an approximate $\mathrm{MgO}$ equivalent of 19.5 to 21.6 percent or magnesium-carbonate equivalent of 41.0 to 45.4 percent." 
Pure limestones are a rarity, but impure limestones are very common. Impure limestones are characterized by their dominant impurity. Adjectives are used to describe limestones based on the impurity such as arenaceous (high in quartz, silicon dioxide, sand); argillaceous (high in clay); carbonaceous (high in carbon); ferruginous or ferriferous (containing iron); bituminous (containing organic hydrocarbons) (McCue et al., 1939). If clay is added to limestone forming calcareous sediments, the result is limestone that grades into shale. If sand is added, the limestone grades into calcareous sandstone and if enough sand is added the limestone will eventually grade into ordinary sandstone (Emmons et al., 1960).

Climatic conditions are the driving force in the weathering of limestone according to Emmons et al. (1960). The most favorable conditions for the dissolution of limestone include warm to hot temperatures and abundant precipitation. According to Goudie (1995), limestone dissolution increases with increasing precipitation. Limestone weathers easily in warm and humid regions and is virtually resistant to chemical weathering in arid and semiarid regions. In arid and semiarid regions mechanical weathering dominates the limestone weathering process (Emmons et al., 1960).

Limestone soils form from insoluble residue that remains after the calcite and/or dolomite has been dissolved and leached from the soil. According to Ciolkosz et al. (1990a) insoluble residue amounts in limestone located in the Valley and Ridge province of central Pennsylvania usually ranges from 3 to 10 percent. Ciolkosz et al. (1995) found an association of limestone rock color with the amount of insoluble residue content. Insoluble residue contents decreased as Munsell color values decreased. Munsell color values of 5 or less (nearing black) were associated with rock that had less that 10 percent insoluble residue. The authors found, in Pennsylvania, that red, clayey Hagerstown (fine, mixed, semiactive, mesic Typic Hapludalfs) soils were formed from dark colored limestones with low quantities of insoluble residue and yellowish brown, silty Duffield (fine-loamy, mixed, active, mesic Ultic Hapludalfs) soils were formed from lighter colored limestones with high quantities of insoluble residue.

Soil color is one of the most common attributes that is recorded and used to differentiate and characterize soils. Soil color is determined by the amount and type of iron oxide minerals present (Schwertmann, 1993; Ciolkosz and Dobos, 1990b; 
Schwertmann and Taylor, 1989). Goethite, the most common soil Fe oxide, imparts a yellowish-brown color to the soil while hematite is responsible for the red color associated with soils. Only small amounts of hematite are needed to mask higher amounts of goethite due to hematite's higher pigmenting power (Schwertmann, 1993; Schwertmann and Taylor, 1989). According to Ciolkosz et al. (1995), the color of Hagerstown soil in Pennsylvania is due primarily to hematite and the color of Duffield is apparently due to goethite.

Limestone weathering produces fine textured soils due to the clay impurities found in limestone. Fine textured (clayey) soils include the textural classes of sandy clay, silty clay, and clay (Soil Survey Division Staff, 1993).

In limestone soils with none to slight erosion, there is a difference between the clay content in the surface horizons compared to the subsoil or B horizons. This difference has been explained by the processes of eluviation and illuviation (Ciolkosz et al., 1994). Other limestone soils, however, have such a strong contrast between the surface horizons and the subsoil that these processes can not totally explain the vast difference that occurs in these soils. It is theorized that these soils have had some other material placed on top of them, primarily eolian in nature, which mixed with the surface horizons (lowering the percent clay content) or was eroded away after the clay had eluviated. In Pennsylvania, Cronce (1988) found significant eolian deposits occurring on limestones in the Nittany Valley, which would support this theory. Ballagh and Runge (1970) used this theory to explain the genesis of clay rich horizons of limestone soils in Illinois. The sharp contrast of clay content between the A and B horizons of Hagerstown soils in Pennsylvania is attributed to a combination of clay illuviation into the B horizons and the addition of eolian silt sized material to the A horizon (Ciolkosz et al., 1995).

Ciolkosz et al. (1995) estimate deep limestone soils to be 1 to 3 million years old in Pennsylvania based on a limestone dissolution rate of $30 \mathrm{~mm} / 1,000$ yrs. They estimate that three meters of Hagerstown soil takes one million years to accumulate from the weathering of the limestone bedrock. 


\section{Clay Mineralogy}

Minerals with a particle size diameter of $<2 \mu \mathrm{m}$ are part of the clay-sized fraction of the soil by definition. According to McBride (1994), the term clay mineral historically refers to the secondary layer silicates but should be broadened to include allophanes and oxidic minerals of $\mathrm{Fe}$ and $\mathrm{Al}$.

Kaolinite is one of the most common clay minerals in soils, especially in highly weathered acidic soils. It is formed primarily by the weathering of primary and secondary minerals, but can be inherited from soil parent material (Dixon, 1989). Kaolinite is a 1:1 layer phyllosilicate mineral composed of an aluminum substituted octahedral sheet and a silicon substituted tetrahedral sheet. It is dioctahedral (two of every three octahedral positions are occupied by $\mathrm{Al}$ ) with very little isomorphous substitution in the tetrahedral or octahedral sheets. There is very little or no layer charge due to the lack of substitution. The ideal formula for kaolinite is $\mathrm{Al}_{2} \mathrm{Si}_{2} \mathrm{O}_{5}(\mathrm{OH})_{4}$. Layers are held tightly together by hydrogen bonding between the $\mathrm{OH}$ ion of the octahedral layer and the $\mathrm{O}$ ion of the tetrahedral layer. This hydrogen bonding does not allow kaolinites to swell in water. The lack of substitution and the strength of hydrogen bonding cause kaolinite to have a low cation exchange capacity and surface area.

Micas are 2:1 layer phyllosilicate minerals, usually inherited from the parent material of the soil, composed of an octahedral sheet between two tetrahedral sheets. Mica occurring in the clay fraction of soils, is often referred to as illite. Illite (hydrous mica) has poorer crystallinity, lower $\mathrm{K}$ content and higher $\mathrm{H}_{2} \mathrm{O}$ content than the macroscopic mica (muscovite) that it resembles (Schulze, 1989). In the tetrahedral sheets of muscovite, one out of every four tetrahedral sites are occupied by $\mathrm{Al}^{3+}$ instead of $\mathrm{Si}^{4+}$. This substitution causes muscovite to have a negative layer charge of about 1 which is balanced by $\mathrm{K}^{+}$that binds adjacent tetrahedral sheets. In the tetrahedral sheet of illite, $\mathrm{Al}^{3+}$ substitutes less for $\mathrm{Si}^{4+}$. Illite has a lower layer charge than that of muscovite ranging from about 0.5 to 1 . Both muscovite and illite are dioctahedral (two of every three octahedral positions are occupied). The octahedral sheet of illite contains more $\mathrm{Fe}^{2+}$ and $\mathrm{Mg}^{2+}$ than the $\mathrm{Al}^{3+}$ found in muscovite. The formulas for muscovite and illite are $\mathrm{K}\left(\mathrm{Al}_{2}\right)\left(\mathrm{Si}_{3} \mathrm{Al}\right) 0_{10}(\mathrm{OH})_{2}$ and $\mathrm{K}_{0.5}\left(\mathrm{Al}_{1.2} \mathrm{Fe}_{0.2} \mathrm{Mg}_{0.3} \mathrm{Fe}_{0.1}\right)\left(\mathrm{Si}_{3.3} \mathrm{Al}_{0.7}\right) \mathrm{O}_{9}(\mathrm{OH})_{3}$, respectively. Layers are bound so tightly by $\mathrm{K}^{+}$that other cations or water can not enter the interlayer 
space. Therefore, micas do not swell in water and have a low cation exchange capacity and surface area compared to other 2:1 minerals. Micas tend to form 2:1 expandable minerals such as vermiculites and smectites upon weathering (Fanning et al., 1989).

Vermiculite is a 2:1 layer phyllosilicate mineral similar in structure to mica and is thought to predominately form from the weathering of mica or chlorite (Douglas, 1989). The layer charge varies from 1 to 2 and is balanced usually by $\mathrm{Mg}^{2+}$ and $\mathrm{Ca}^{2+}$ in the interlayer space accompanied by two layers of water. Vermiculite can be dioctahedral or trioctahedral. Dioctahedral vermiculites are more common in the clay fraction of the soil than the larger particle trioctahedral vermiculites. The high layer charge causes vermiculite to have a high cation exchange capacity, however layer separation may be limited because of the negative layer charge in the tetrahedral layer and exchangeable cations in the interlayer are being pulled together. Vermiculite has the highest cation exchange capacity of the clay minerals. Although some swelling of vermiculite in water occurs, it is limited compared to the smectite minerals.

Smectite is a 2:1 layer phyllosilicate mineral with a structure similar to mica and vermiculite that can be inherited from soil parent material or formed from weathering of mica or chlorite. Most smectites have been called montmorillonite even though they may contain tetrahedral $\mathrm{Al}$ and octahedral $\mathrm{Fe}$ in relatively large amounts (Borchardt, 1989). Smectites containing tetrahedral $\mathrm{Al}$ and octahedral $\mathrm{Fe}$ are beidellite and nontronite, respectively. Isomorphous substitution of $\mathrm{Al}^{3+}$ for $\mathrm{Si}^{4+}$ in the tetrahedral sheet and $\mathrm{Mg}^{2+}$ and $\mathrm{Fe}^{2+}$ for $\mathrm{Al}^{3+}$ and $\mathrm{Fe}^{3+}$ in the octahedral sheet of smectite produces a layer charge which varies from about 0.5 to 1 . Smectite can be dioctahedral or trioctahedral; however, trioctahedral smectites are thought to be inherited from the parent material and seldom able to survive pedogenesis. Therefore, they are rarely found in soils. Ideal formulas of dioctahedral smectites include: montmorillonite $\left(\mathrm{Si}_{4} \mathrm{Al}_{1.5} \mathrm{Mg}_{0.5} \mathrm{O}_{10}(\mathrm{OH})_{2} \mathrm{Ca}_{0.25}\right)$, beidellite $\left(\mathrm{Si}_{3.5} \mathrm{Al}_{0.5} \mathrm{Al}_{2} \mathrm{O}_{10}(\mathrm{OH})_{2} \mathrm{Ca}_{0.25}\right)$, and nontronite $\left(\mathrm{Si}_{3.5} \mathrm{Al}_{0.5} \mathrm{Fe}_{2} \mathrm{O}_{10}(\mathrm{OH})_{2} \mathrm{Ca}_{0.25}\right)$. The layer charge in montmorillonite is produced from the substitution of $\mathrm{Mg}^{2+}$ for $\mathrm{Al}^{3+}$ in the octahedral sheet. The layer charge in beidellite and nontronite is produced in the tetrahedral sheet. The cation exchange capacity of smectite is lower than vermiculite due to the lower layer charge. Swelling of smectite in water is high due to the large surface area, small size, and negatively charged layer structure. Upon weathering, smectite may 
form hydroxy-interlayed vermiculite, hydroxyl-interlayed smectite, pedogenic chlorite, interstratified kaolinite-smectite, kaolinite or completely dissolve depending on the amount and intensity of the weathering.

Chlorite is a 2:1 layer phyllosilicate mineral that is thought to be inherited from the soil parent material and once again is similar in structure to mica and vermiculite. The only difference being that chlorite contains an interlayer hydroxide sheet (Barnhisel and Bertsch, 1989). Chlorites can be dioctahedral or trioctahedral, dioctahedral being the most common in the clay-sized soil fraction. Again negative layer charge is produced in the tetrahedral sheets primarily by $\mathrm{Al}^{3+}$, but occasionally by $\mathrm{Fe}^{3+}$ or $\mathrm{Cr}^{3+}$, substitution for $\mathrm{Si}^{4+}$. A positive charge is produced by substitution of $\mathrm{Al}^{3+}$ or $\mathrm{Fe}^{3+}$ for $\mathrm{Mg}^{2+}$ or $\mathrm{Fe}^{2+}$ in the interlayer hydroxide sheet. This positive charge reduces the negative charge produced by the tetrahedral substitution and hence lowers overall negative layer charge. With the interlayer hydroxide sheet essentially blocking cations and water from entering the interlayer and relatively small negative layer charge, chlorite has a relatively small surface area, low cation exchange capacity and does not swell in water. Chlorite weathers to form vermiculite, smectite, interstratified clay minerals and hydroxyinterlayered clay minerals.

Hydroxy-interlayed clay minerals are chlorite-like minerals without a complete hydroxide sheet in the chlorite structure. Hydroxy-interlayered vermiculite (HIV) and smectite (HIS) are suggested acronyms for hydroxyl-Al interlayered vermiculite and smectite in an attempt to standardize terminology used in reference to soil clays (Barnhisel and Bertsch, 1989). These minerals are highly variable in composition. Layer structure is determined by the basic 2:1 clay mineral structure and the type and amount of hydroxy-interlayer materials present. Cation exchange capacity of these minerals is dependent upon the amount of available interlayer space. Cation exchange capacity is lowered as the interlayer space is filled and approaches CEC values for smectites and vermiculites when the interlayer space is nearly empty. There is little swelling in hydroxy-interlayered clay minerals which is thought to be caused by the presence of $\mathrm{Al}$ in the interlayer. These minerals are ultimately thought to weather to kaolinite.

Interstratified minerals, also referred to as mixed layer minerals, can occur in soils as a single mineral made up of layers from two or three different layer silicate minerals 
(mica, vermiculite, smectite, chlorite, and kaolinite). Interstratified minerals can be formed by hydrothermal alteration or weathering in which $\mathrm{K}$ is partially removed from the interlayer in mica and hydroxide-interlayers are removed from chlorite. Interstratified minerals can also form by intercalating $\mathrm{K}$ and other similar ions and the formation of hydroxide-interlayers in vermiculite, smectite and expanding-layer silicates (Sawhney, 1989). Because these layer silicate minerals have the same basic structural units (tetrahedral and octahedral sheets) and the units are structurally similar, mixing of layers may occur causing the formation of a separate mineral. Two- and three-component system minerals can occur with some common two-component minerals including: micavermiculite, mica-smectite, mica-chlorite, chlorite-vermiculite, chlorite-smectite, chlorite-swelling chlorite, and kaolinite-smectite. The sequencing of layers can be random or regular, with random mixing occurring more commonly in soils.

Quartz, goethite, hematite, and gibbsite among other minerals, also are commonly found in soils. Quartz is often the most abundant mineral in soils and is concentrated in the sand and silt fractions with small quantities occurring in the clay fraction (Dress et al., 1989). Silica minerals such as quartz have no significant isomorphic substitution or surface charge and have very low if any cation exchange capacity. Goethite and hematite are Fe oxide minerals that are responsible for the soil's color (Schwertmann and Taylor, 1989). Gibbsite is the most common Al hydroxide mineral occurring in soils (Hsu, 1989). It is found in soils with advanced weathering. Iron and Al oxides have very low cation exchange capacities due to the lack of isomorphic substitution, but can develop surface charges and may become sinks for cations and inorganic and organic anions (McBride, 1994).

\section{Mechanics of Soil Shrink-Swell}

Argillipedoturbation is a process that affects smectite laden clay soils in areas that have a climate that induces repeated wetting and drying cycles (Fanning and Fanning, 1989). Argillipedoturbation is the mixing of soil due to shrinking and swelling of expansive clays which accompany drying and wetting cycles (Buol et al., 2003). It is often considered the major process that forms Vertisols. When clays are swollen in a moist condition, vertical cracks in the soil are closed. Upon drying, the clay contracts or 
shrinks and cracks are formed in the soil. As precipitation such as rainfall enters the open cracks and wets the soil the clay expands, increasing in volume and forcing the soil in the direction of least resistance. This movement, normally in an upward fashion, creates gilgai and slickensides (Fanning and Fanning, 1989).

Gilgai is defined by Soil Survey Staff (2007) as the following: "A microfeature pattern of soils composed of a succession of microbasins and microknolls on level areas, or of microtroughs and microridges parallel to the slope on sloping areas, and produced by expansion / contraction and shear / thrust processes with changes in soil moisture. Found in soils containing large amounts of smectitic clay that swell and shrink considerably with wetting and drying. Various types of gilgai can be recognized based on the dominant shape of micro-highs and micro-lows: circular gilgai, elliptical gilgai, and linear gilgai."

Soil Survey Staff (2006) defines slickensides as follows: "Slickensides are polished and grooved surfaces and generally have dimensions exceeding $5 \mathrm{~cm}$. They are produced when one soil mass slides past another. Some slickensides occur at the lower boundary of a slip surface where a mass of soil moves downward on a relatively steep slope. Slickensides result directly from the swelling of clay minerals and shear failure. They are very common in swelling clays that undergo marked changes in moisture content." Interpretations regarding shrink-swell capacity and potential, which affect soil stability and suitability for agricultural and nonagricultural uses of soils, may be made from observing slickensides in the field (Buol et al., 1997).

All clays may exhibit some shrinking and swelling with changes in moisture content, but smectites exhibit drastic changes compared to other clays. The small size, large surface area, and negative layer charge allow smectite to adsorb several times its weight in $\mathrm{H}_{2} \mathrm{O}$ (Borchardt, 1989). Montmorillonite saturated with divalent cations such as $\mathrm{Ca}^{2+}$ and $\mathrm{Mg}^{2+}$ will swell from 1 to $2 \mathrm{~nm}$ or $100 \%$ (Norrish, 1954). Montmorillonite saturated with a monovalent cation such as $\mathrm{Na}^{+}$or $\mathrm{Li}^{+}$will theoretically swell to infinity. Interstatification with other nonexpansive clay minerals and saturation of the interlayer with $\mathrm{K}^{+}$(due to is large size) and divalent cations $\mathrm{Ca}^{2+}$ and $\mathrm{Mg}^{2+}$ rather than monovalent $\mathrm{Na}^{+}$or $\mathrm{Li}^{+}$prevent smectites in soils from expanding to their maximum potential (Borchardt, 1989). Kaolinites occurring in large amounts in soils with high fine clay 
contents have been observed as acting similar to smectites in physical behavior due to their large surface area (Yerima et al., 1985, 1987).

The concept of clay swelling is the balancing of forces of interaction among the clay surface, ions and water. However, agreement on an appropriate model of clay expansion has not been reached (McBride, 1989). There are two basic viewpoints that explain the swelling of smectites. In one viewpoint, Sposito (1973) stressed that osmotic forces produced by exchangeable cations dissociated from the clay surface cause the swelling pressure. According to Sposito et al. (1983) exchangeable cations play a major role in organizing the water structure on montmorillonite of varying charge. In another viewpoint, Low and Margheim (1979) stressed that swelling pressure is primarily due to a reduction in the potential energy of the interlayer water as a result of its interaction with the adjacent layer surfaces, although they acknowledge that osmotic forces may also play a small role. In further research, Low $(1980,1981)$ attributed swelling primarily to the interaction between water and adjacent clay surfaces.

The double layer theory, or the viewpoint expressed by Sposito (1973) above, provides the best explanation for swelling pressure at high water contents and large interlayer distances (Borchardt, 1989). At low to moderate interlayer distances, montmorillonites with widely varying charge densities produced nearly identical swelling pressure, which support the reduction in potential energy theory, viewpoint two (Viani et al., 1983).

\section{Measuring and Predicting Soil Shrink-Swell}

Currently there is no one field or laboratory method that accurately estimates soil shrink-swell potential for all types of soils. Combinations of field observations and laboratory measurements of physical, chemical, and mineralogical properties are currently being used by soil scientists and engineers to best predict soil shrink-swell potential.

Smectite content is considered to be the factor most commonly associated with soil shrink-swell potential (Borchardt, 1989; Karathanasis and Hajek, 1985; Ross, 1978; Schafer and Singer, 1976; Yaalon and Kalmar, 1972; Franzmeier and Ross, 1968; Davidson and Page, 1956). 
However, soils with significant amounts of expansive clays give field indications of soil pedoturbation by the presence of slickensides (Buol et al., 1997) or by soil cracking. Shrinkage is a process that occurs as hydrated clay dries (Hillel, 1998). Shrinkage occurring at the surface will cause cracks to form that break the soil up into various size fragments ranging from small to large aggregates. This process can be easily seen in Vertisols. These soils, upon repeated wetting and drying cycles, tend to heave and settle, forming wide, deep cracks and slanted sheer planes that extend deep into the soil profile. The presence of cracks is required for Vertisol classification and is a component of the vertic subgroup classification (Soil Survey Staff, 2006).

Most research on expansive soils has been conducted on Vertisols or soils that have predominately smectitic type clays with high base saturation. These studies have found numerous soil properties correlated to shrink-swell. Yerima et al. (1989) determined that surface area, percent total clay, and water retention at $33 \mathrm{kPa}$ pressure were highly correlated to coefficient of linear extensibility (COLE) in Vertisols and associated Alfisols of northern Cameroon. Schafer and Singer (1976) found that percent expandable clay described the variations in swelling of soils in Yolo County, California. In Ohio, McCormack and Wilding (1975) found that the variation in clay content where other parameters were held constant explained the shrink-swell of Geeburg (fine, illitic, mesic Aquic Hapludalfs) and Canfield (fine-loamy, mixed, active, mesic Aquic Fragiudalfs) soils. Shrink-swell potential measured by Anderson et al. (1973) related fine clay percentages and exchangeable Na percentages to variations of coefficient of linear extensibility in Usterts and Torrerts. Dasog et al. (1988) concluded that fine clay content reasonably predicted COLE and served as a measure for predicting shrink-swell potential of soils derived from glaciolacustrine sediments. Clay content and specific surface area (SSA) were correlated to shrink-swell potential of soils in Ontario, Quebec, and Tanzania, with SSA explaining more of the variability in shrink-swell potential than the clay content (Ross, 1978). In Alabama, Gill and Reaves (1957) found that cation exchange capacity (CEC) was more closely correlated to shrinkage of natural clods than SSA or plasticity index. In montmorillonitic soils in Alabama, Karathanasis and Hajek (1985) found that CEC was correlated to COLE in soils with vertic characteristics. 
Liquid limit, clay content, and CEC were correlated to swell indices in five mapping units in the Culpeper Basin of Virginia (Thomas et al., 2000a).

Plasticity index is the most commonly used indicator of soil shrink-swell properties (Borchardt, 1989). Plasticity index is defined as the difference between the liquid and the plastic limit. It indicates the potential plasticity of a soil and is widely used in engineering classification systems for soils (Casagrande, 1948). Liquid limit is defined by the American Society for Testing and Materials (2000) as "the water content, in percent, of a soil at the arbitrarily defined boundary between the semi-liquid and plastic states" or simply the water content at which point the soil begins to flow. Plastic limit is defined by the American Society for Testing and Materials (2000) as "the water content, in percent, of a soil at the boundary between plastic and semi-solid states". Plastic limit is characterized by a sample of soil with a water content which allows the sample to be rolled into a thread of $3 \mathrm{~mm}$ in diameter without breaking. Liquid limit, plastic limit, and plasticity index are collectively referred to as Atterberg limits. The Atterberg limits determine the moisture content of soil as the soil changes consistency states (Casagrande, 1948).

In Virginia, Thomas et al. (2000b) developed an expansive soil rating system, termed the Expansive Soil Index (ESI), using the soil properties most correlated with shrink-swell potential. The Expansive Soils Indices (ESI) are obtained by summing the absolute values of swelling 2:1 minerals, swell index, liquid limit, and CEC. Three levels of precision are available with the highest precision obtained with all four properties. Intermediate precision is available by using swell index, liquid limit, and CEC. Lower precision, but rapid assessment, can be achieved by using only liquid limit and CEC. The ESI system has the flexibility of allowing for the classification of other soils formed from similar parent materials.

Although other methods may exist, the coefficient of linear extensibility (COLE) method is a widely recognized and accepted method for measuring soil shrink-swell. Coefficient of linear extensibility developed as an application of bulk density data (Grossman et al., 1968). The National Soil Survey Laboratory traditionally uses COLE to make inferences about shrink-swell potential (Soil Survey Staff, 2004). Natural soil clods are coated with a flexible plastic resin (saran) that is permeable to water vapor, but 
impermeable to liquid water. A tension table or vacuum desiccator is used to bring the clods to equilibrium at saturation. Then the clods are brought to a moisture potential equivalent to $33 \mathrm{kPa}$ by using a pressure plate extractor. Next, the clods are weighed in air and water. Clods are then oven-dried at $105^{\circ} \mathrm{C}$ and weighed in air and water again. Water content and bulk densities can be calculated from the weights of the clod in air and water. The change in volume of the clod between the $33 \mathrm{kPa}$ and oven-dry state is the COLE. Coefficient of linear extensibility is determined on the $<2 \mathrm{~mm}$ fraction and is calculated as follows assuming there are no coarse fragments:

$$
\operatorname{COLE}=\left(\mathrm{Db}_{\mathrm{d}} / \mathrm{Db}_{\mathrm{m}}\right)^{0.33}-1
$$

where $\mathrm{Db}_{\mathrm{d}}$ is the corrected bulk density of the oven dry clod and $\mathrm{Db}_{\mathrm{m}}$ is the corrected bulk density of the moist clod at $33 \mathrm{kPa}$ (Brasher et al., 1966; Franzmeier and Ross, 1968; Grossman et al., 1968). Tunney (1970) indicated that the potential volume change in clods of swelling soils, where the moisture content needed to be adjusted to a higher level after the saran coating had been applied, may not be achieved due to restriction by the saran coating. Shrink-swell potentials can be estimated from COLE values as follows (Soil Survey Staff, 2007):

$\begin{array}{ll}\frac{\text { COLE }}{<0.03} & \text { Shrink-Swell Class } \\ 0.03 \text { to } 0.06 & \text { Low } \\ 0.06 \text { to } 0.09 & \text { Moderate } \\ >0.09 & \text { High }\end{array}$

\section{Soil Classification}

Shrink-swell is a soil genetic process that has considerable importance in soil classification (Buol et al., 1997). Soils with high shrink-swell potential are commonly classified as Vertisols or soils with a vertic subgroup. Vertisols and soils with vertic subgroups are very similar in characteristics such as instability due to swelling, clay content, clay mineralogy, COLE, plasticity index, liquid limit, $1500 \mathrm{kPa}$ (15 bar) water, 
and CEC (Bartelli and McCormack, 1976). Vertisols and soils with vertic subgroups both belong to the $\mathrm{CH}$ group (clayey soils with high liquid limits) in the Unified Soil Classification System (DeMent and Bartelli, 1969).

Vertisols occur in the Key to Soil Orders of Soil Taxonomy (Soil Survey Staff, 2006) following Gelisols, Histosols, Spodosols, Andisols, and Oxisols, as "Other soils that have:

1) A layer $25 \mathrm{~cm}$ or more thick, with an upper boundary within $100 \mathrm{~cm}$ of the mineral soil surface, that has either slickensides or wedge-shaped peds that have their long axes tilted 10 to 60 degrees from the horizontal; and

2) A weighted average of 30 percent or more clay in the fine-earth fraction either between the mineral soil surface and a depth of $18 \mathrm{~cm}$ or in an Ap horizon, whichever is thicker, and 30 percent or more clay in the fine-earth fraction of all horizons between a depth of $18 \mathrm{~cm}$ and either a depth of $50 \mathrm{~cm}$ or a densic, lithic, or paralithic contact, a duripan, or a petrocalcic horizon if shallower; and

3) Cracks that open and close periodically."

Vertisols are mapped throughout the world with the largest areas occurring in Australia (80,000,000 ha), India (73,000,000 ha), Sudan (50,000,000 ha), and the United States (18,000,000 ha) (Soil Survey Staff, 1999). In the United States, Vertisols occur in 25 states with the largest areas occurring in Texas $(6,500,000$ ha), South Dakota (1,500,000 ha), California (1,000,000 ha), and Montana (600,000 ha) (Coulombe et al., 2000).

Vertic subgroups have been defined in Alfisols, Aridisols, Entisols, Gelisols, Inceptisols, Mollisols, and Ultisols. Keys to Soil Taxonomy (Soil Survey Staff, 2006) differentiates vertic subgroups from typic subgroups in the same great group by having "one or both of the following:

1) Cracks within $125 \mathrm{~cm}$ of the mineral soil surface that are $5 \mathrm{~mm}$ or more wide through a thickness of $30 \mathrm{~cm}$ or more for some time in normal years and slickensides or wedge-shaped aggregates in a layer $15 \mathrm{~cm}$ or more thick that has its upper boundary within $125 \mathrm{~cm}$ of the mineral soil surface; or 
2) A linear extensibility of $6.0 \mathrm{~cm}$ or more between the mineral soil surface and either a depth of $100 \mathrm{~cm}$ or a densic, lithic, or paralithic contact, whichever is shallower."

Soils most common to the vertic subgroup have more than 40 percent clay in the subsoil and are dominated by montmorillonitic clay (DeMent and Bartelli, 1969).

An earlier edition of Soil Taxonomy (Soil Survey Staff, 1975) described vertic subgroups as having "the following characteristics:

1) Cracks at some period in most years that are $1 \mathrm{~cm}$ or more wide at a depth of $50 \mathrm{~cm}$, that are at least $30 \mathrm{~cm}$ long in some part, and that extend to the surface or to the base of an Ap horizon;

2) A coefficient of linear extensibility (COLE) of 0.09 or more in a horizon or horizons at least $50 \mathrm{~cm}$ thick and a potential linear extensibility of $6 \mathrm{~cm}$ or more in the upper $1 \mathrm{~m}$ of the soil or in the whole soil if a lithic or paralithic contact is deeper that $50 \mathrm{~cm}$ but shallower than 1m; and

3) More than 35 percent clay in horizons that total $>50 \mathrm{~cm}$ thickness within the control section."

In the udic moisture regime of Alabama, Karathanasis and Hajek (1985) studied thirty-two pedons representative of Vertisols, Inceptisols, and aquic, typic, and vertic subgroups of Alfisols and Ultisols. The authors found discrepancies between laboratory measured and field observed shrinking of aquic/typic/vertic Ultisols primarily due to lack of wide cracks. At that time, the lack of evidence of wide or deep cracking kept the vertic subgroup out of the classification of montmorillonitic Hapludults. The authors suggested that either laboratory data or field data, not both, be used for the vertic subgroup definition so that the agronomic and/or engineering limitations of these soils would be accounted for in classification. This change in classifying vertic subgroups would eventually take place and is currently being utilized as previously stated. 


\section{Materials and Methods}

\section{Study location}

The study area was located in the Great Valley of the Valley and Ridge Physiographic Province in Berkeley and Jefferson counties of West Virginia. The Great Valley (also referred to as the Shenandoah Valley locally) is a $32 \mathrm{~km}$ (20 mi) wide, gently rolling valley between the Blue Ridge Mountains, to the east, and North Mountain, to the west.

Limestone and shale rocks underlying the Great Valley are severely folded, fractured, and faulted even though the topography of the valley is relatively flat (Lessing, 1979). The gentle topography can be attributed to the erosion and weathering of the relatively non-resistant carbonate (limestone) and shale formations in the Valley (Dean, 1966). The floor of the Great Valley in West Virginia is primarily limestone in the west and limestone and shales in the east (Grimsley and White, 1916).

Development and planning issues of extreme complexity have arisen due to the chemical limestone dissolution that occurs and the complicated geology that underlies the Valley (Lessing, 1979). Caverns, sinkholes, and springs are common in the purer limestones throughout the Valley (Dean, 1966).

The geology of the Valley creates agricultural benefits by producing landscapes of relatively gentle topography (Lessing, 1979). Alfisols and some Ultisols make up the dominant soils in the Valley, with Inceptisols interspersed on the ridges (van Eck, 1979). The Great Valley is one of the most important agricultural regions of West Virginia. Berkeley County ranked number one in West Virginia in market value of crops (including nursery and greenhouse) sold in 2002. Berkeley County also ranked $11^{\text {th }}$ in the state in market value of livestock, poultry, and their products sold and ranked $6^{\text {th }}$ in total value of agricultural products sold in 2002 (National Agricultural Statistics Service, 2004). Jefferson County ranked $3^{\text {rd }}$ in market value of crops (including nursery and greenhouse) sold in West Virginia in 2002. Jefferson County also ranked $8^{\text {th }}$ in the state in market value of livestock, poultry, and their products sold and ranked $7^{\text {th }}$ in total value of agricultural products sold in 2002 (National Agricultural Statistics Service, 2004). 
Average air temperature of the study area in the winter is $0^{\circ} \mathrm{C}\left(32^{\circ} \mathrm{F}\right)$ and in the summer is $22.8^{\circ} \mathrm{C}\left(73^{\circ} \mathrm{F}\right)$ (Bell, 2002). Total annual precipitation is $95.35 \mathrm{~cm}$ (37.54 in), of which 54 percent usually falls in April through September. The average relative humidity in mid-afternoon is about 54 percent and at dawn about 77 percent. The sun shines 63 percent of the time during summer and 52 percent during winter. The prevailing wind is from the west-northwest.

\section{Soils}

Carbo (very-fine, mixed, active, mesic Typic Hapludalfs), Swanpond (very-fine, mixed, active, mesic Vertic Paleudalfs) and Hagerstown (fine, mixed, semiactive, mesic Typic Hapludalfs) soils were selected for this study. Carbo and Swanpond soils were selected because of apparent properties related to a high shrink-swell potential. Although the Hagerstown soil does not show properties related to a high shrink-swell potential, this soil was selected because it is very clayey and occurs widely throughout the Valley and Ridge Physiographic Province. The Hagerstown soil was used for comparison to the Carbo and Swanpond soils. Official series descriptions for these soils can be found in Appendices A, B, and C. These soils are being used for pasture, hay land, forestland, cropland, and urbanization. Swanpond silt loam and Hagerstown silt loam soils are considered prime farmland. Major limitations of the Carbo and Swanpond soils for land use include depth to bedrock (Carbo), high shrink-swell potential, slow permeability, and low strength.

Carbo soils formed from materials weathered from limestone bedrock, primarily the Chambersburg and New Market limestones in Berkeley County. These soils are moderately deep, well-drained and slowly permeable (Bell, 2002). They have a dark brown silt loam to clay surface layer. The subsoil is strong-brown or yellowish-brown silty clay to clay that is plastic and sticky (Gorman et al., 1960). Depth to bedrock ranges from 50 to $100 \mathrm{~cm}$ (20 to $40 \mathrm{in}$ ). The available moisture capacity is moderate to low. Shrink-swell potential for Carbo soils is high and surface runoff is medium to very rapid (Bell, 2002).

In Berkeley County, the Carbo soils occur in narrow strips and bands in the Great Valley, mostly along and southeast of U.S. Highway 11. Most areas of Carbo soils have 
been cleared and are used for pasture or general farming. Even though these finetextured soils are difficult to till, they are susceptible to severe erosion (Gorman et al., 1960).

Soils of the Swanpond series are very deep, moderately well-drained and slowly permeable. They form in residuum weathered from limestone located in topographically low areas where the Chambersburg and Beekmantown limestones converge (James Bell, NRCS Soil Scientist, personal communication). They have a surface layer of brown silt loam to silty clay loam. The subsoil is yellowish brown or strong brown clay to silty clay that has redox depletions below $75 \mathrm{~cm}$ (30 in) (Soil Survey Staff, 2008). Depth to bedrock is greater than $150 \mathrm{~cm}$ (60 in). Available moisture capacity is moderate to high in Swanpond soils. Shrink-swell potential is high in the subsoil and surface runoff is slow to medium (Bell, 2002).

Most areas of Swanpond soils are used for cultivated crops, pasture, and hay land. Some areas are used for urban development. A small acreage is in woodland of mixed hardwoods (Soil Survey Staff, 2008).

Hagerstown soils form from limestone residuum, primarily members of the Beekmantown Group. These soils are very deep, well-drained and moderately permeable. They have a surface layer that is brown silt loam to silty clay loam. The subsoil is variegated strong brown, yellowish red, and dark yellowish brown clay to silt loam. Depth to bedrock ranges from 150 to $180 \mathrm{~cm}$ (60 to 72 in). The available moisture capacity is moderate to high. Shrink-swell potential is moderate in the subsoil and surface runoff is medium to rapid (Bell, 2002).

Most areas of Hagerstown soils have been cleared and are used for orchards, pasture, hay land, cultivated crops, and urban development. A small acreage is in woodland (Bell, 2002).

\section{Geology}

This study concentrated on soils forming from the Chambersburg and Beekmantown limestones. The Chambersburg Limestone was formed during the Ordovician period of the Paleozoic Era. Chambersburg Limestone was the name given to 
the formation by George W. Stose based on exposures west of Chambersburg, Pennsylvania (Grimsley and White, 1916).

The Chambersburg Limestone has been extensively quarried (Bell, 2002). This limestone overlies the Stones River Limestones and is overlain by the Martinsburg Shale in a gradational contact (Grimsley and White, 1916). Dean (1966) estimated the thickness of the transition zone between the Martinsburg Shale and the Chambersburg Limestone to be at least $30 \mathrm{~m}(100 \mathrm{ft})$, even though an exact thickness is unknown. Upper beds of the Chambersburg Limestone can be very shaly in some areas. In these areas, the formation weathers to a calcareous shale which grades into the lower divisions of the Martinsburg Shale (Grimsley and White, 1916). The Chambersburg Limestone is thought to be about 60 to $180 \mathrm{~m}$ (200 to $600 \mathrm{ft}$ ) thick according to Grimsley and White (1916).

The Chambersburg Limestone in the Eastern Panhandle is described by Grimsley and White (1916) as being "a dark-gray or blue to black hard granular rock marked by calcite streaks and crystals often along the joint-planes". Dean (1966) described the limestone as "dark, crystalline and argillaceous". Upon weathering, the limestone turns to a gray or bluish-gray color with yellowish bands of clay material. A recognizable feature of the Chambersburg Limestone is the cobbly appearance that occurs on weathered outcrops. Outcrops often weather to a mass of pebbles or cobbles. This cobblestone effect (nodular bedding) is formed upon weathering due to the bands of clayey material that occur in the joints of the limestone. Although ledges of the limestone contain many fossils, they are not easily collected due to the extremely hard nature and unpredictable breaking of the rock (Grimsley and White, 1916).

Irregular, linear belts of the Chambersburg Limestone occur in West Virginia on both flanks of the Massanutten synclinorium (Dean, 1966). Outcrops of the Chambersburg Formation are found in eastern Berkeley County and southwestern Jefferson County. These outcrops are typically long and narrow, however broad surface outcrops occur near the ends of folds where the strata dips low (Grimsley and White, 1916). The limestone also crops out within the shale belt at numerous locations (Dean, 1966). According to Dean (1966), the best exposures of the Chambersburg Limestone in 
West Virginia occur near Blairton on Route 45 in Berkeley County and east of the Opequon Creek bridge on Route 51 in Jefferson County.

The Beekmantown Limestone also was formed during the Ordovician period of the Paleozoic Era. Beekmantown was the name given by John Clarke and Charles Schuchert based on exposures near Beekmantown, New York (Dean, 1966). The basal portion of the Beekmantown Limestone was named the Stonehenge Limestone by George Stose in the Chambersburg, Pennsylvania area (Grimsley and White, 1916). The Beekmantown Limestone was raised to group status and subdivided into three formations (Stonehenge Limestone, Rockdale Run Formation and Pinesburg Station Dolomite) by William Sando (1956). Stonehenge Limestone was used as the basal unit, Rockdale Run Formation was introduced as the middle unit and Pinesburg Station Dolomite was introduced as the upper unit. Stoufferstown Member of the Stonehenge Limestone was later introduced by Sando (Dean, 1966).

The Beekmantown Limestone overlies the Conococheague Limestone and is overlain by the Stones River Formation. The Beekmantown is a series of magnesium limestones with beds of relatively pure carbonate limestones, dolomites and cherts. Belts of the relatively pure carbonate limestones occurring in the Beekmantown are low in silicia, dove-colored and have smooth fracture. These belts can be mistaken for the similar Upper Stones River. High silica dolomites and magnesium limestones comprise the main portion of the Beekmantown. Magnesium limestones in the main portion of the Beekmantown are described as dark-blue to bluish-gray in color, hard and compact which are grading into dolomites. Large quantities of chert are associated with dolomites of the Beekmantown at various depths. This chert is described as being platy and rounded in shape and yellow to white in color.

The Beekmantown outcrops cover large areas in both Berkeley and Jefferson counties. One outcrop in Berkeley County extends from the Potomac River northwest of Falling Waters, southwest by Bunker Hill to the Virginia state line. The average width of this outcrop is one and a half to two miles. Outcrops of chert horizons in the Beekmantown form ridges and hills throughout the two counties (Grimsley and White, 1916). 


\section{Field Sampling}

Sampling sites were selected by James Bell, Natural Resource Conservation Service (NRCS) soil scientist. Four pedons of the Swanpond series and three pedons each of the Carbo and Hagerstown series were sampled in Berkeley and Jefferson counties, WV (Fig. 1). The sites selected for the study were primarily concentrated in Berkeley County because at the time of sampling the Berkeley County Soil Survey update was in progress. Two Hagerstown pedons were selected in Jefferson County because they were located on government properties and provided easy accessibility. Bedrock geology of each sampling site was determined using a combination of the Geology of the Hedgesville, Keedysville, Martinsburg, Shepherdstown, and Williamsport Quadrangles, Berkeley and Jefferson Counties, WV map (Dean et al., 1987) and geographical information systems (GIS).

Pits were excavated for each of the 10 pedons to a minimum depth of $150 \mathrm{~cm}(60$ in) or to bedrock. Soil profiles were described using standard soil survey procedures (Soil Survey Division Staff, 1993). Upon completion of the soil profile description, bulk samples and three or four soil clods were collected from each horizon for chemical and physical laboratory analyses. Each pedon was excavated, described, and sampled in one day or two consecutive days.

\section{Laboratory Analyses}

\section{Physical Properties}

Bulk samples were air dried and sieved to remove rock fragments greater than 2 $\mathrm{mm}$. The soil and rock fragments were weighed and rock fragment percentage by weight for each horizon was calculated. The $<2 \mathrm{~mm}$ soil fraction was then used for physical, chemical and mineralogical analyses.

Samples of the $<2 \mathrm{~mm}$ fraction of the Hagerstown and Swanpond soils were split into two separate samples with one-half being sent to the National Soil Survey Laboratory in Lincoln, Nebraska. The National Soil Survey Laboratory conducted chemical and physical analyses for the Hagerstown and Swanpond $<2 \mathrm{~mm}$ fraction, with the exception of $33 \mathrm{kPa}$ water content, total elemental analysis, and Atterberg limits. Graduate students at West Virginia University's Division of Plant and Soil Sciences soil 


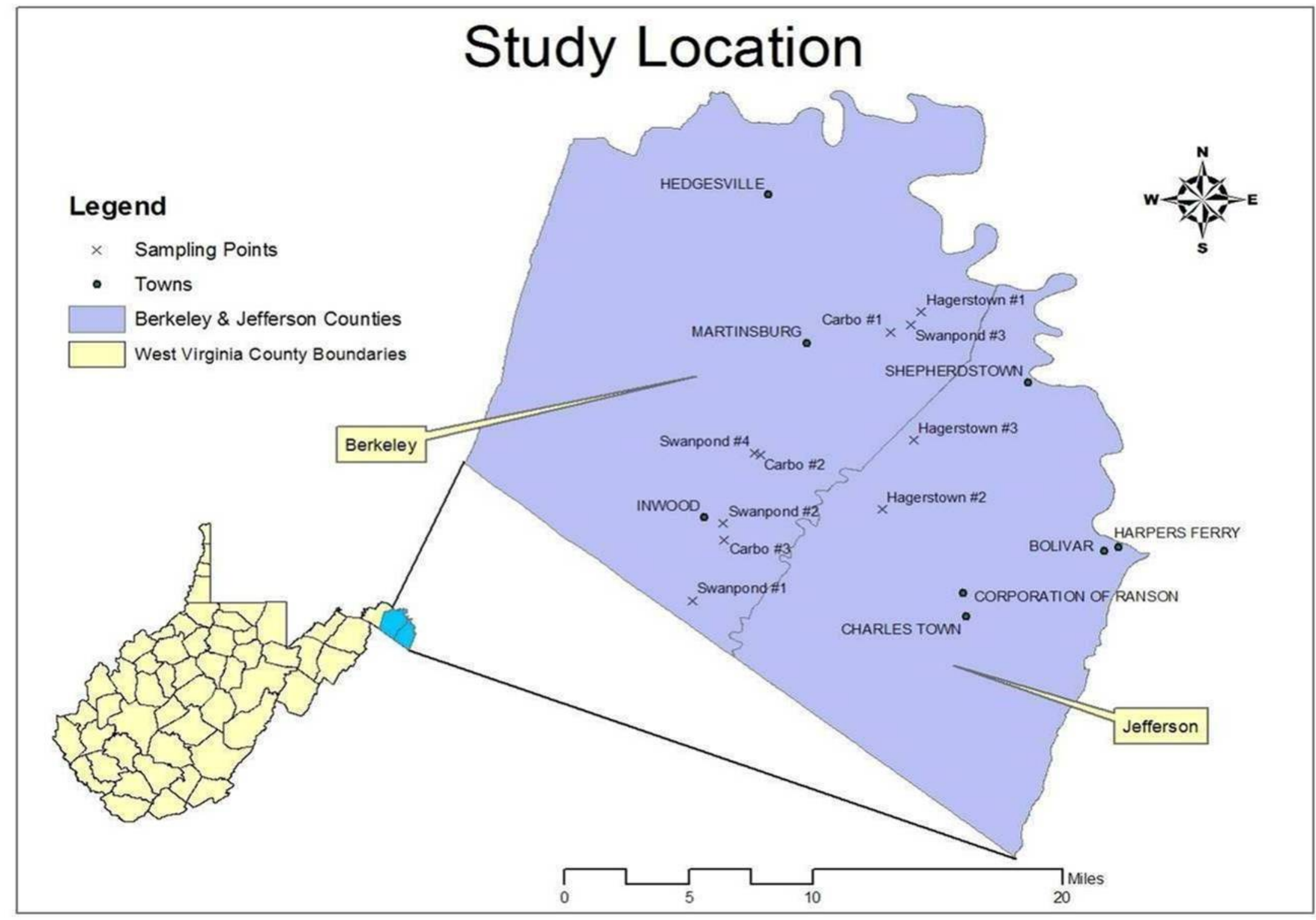

Figure 1. Location of study area and sampling points. 
research laboratory conducted all soil clod related analyses, $33 \mathrm{kPa}$ water content, total elemental analysis, and Atterberg limits for each of the 10 pedons and all physical and chemical analyses for the Carbo pedons. To ensure that chemical and physical results were consistent between the two laboratories, a limited number of samples of the Hagerstown and Swanpond soils also were analyzed at the West Virginia University Division of Plant and Soil Sciences laboratory for comparison.

Total (uncorrected) and $<2 \mathrm{~mm}$ (corrected) $33 \mathrm{kPa}$ and oven-dry bulk densities were determined on three soil clods for each horizon using the saran-coated clod method (Method 3B1b, 3B1c, Soil Survey Staff, 2004).

Coefficient of linear extensibility (COLE) was determined on three saran coated soil clods for each horizon (Method 3D4A, Soil Survey Staff, 2004).

Water content was measured at $33 \mathrm{kPa}$ and $1500 \mathrm{kPa}$ on the $<2 \mathrm{~mm}$ soil fraction using pressure plate extraction and pressure membrane extraction methods, respectively (Method 4B1a, 4B2a, Soil Survey Staff, 1996). Water retention difference between 33 $\mathrm{kPa}$ and $1500 \mathrm{kPa}$ tension in the whole soil was calculated as follows:

$$
\mathrm{WRD}_{\mathrm{ws}}=\left[\left(\mathrm{W}_{33<2 \mathrm{~mm}}-\mathrm{W}_{1500<2 \mathrm{~mm}}\right) \times\left(\mathrm{Db}_{33<2 \mathrm{~mm}}\right) \times \mathrm{Cm}\right] /\left(\mathrm{P}_{\mathrm{w}} \times 100\right)
$$

where $\mathrm{WRD}_{\mathrm{ws}}$ is the volume fraction $\left(\mathrm{cm}^{3} / \mathrm{cm}^{3}\right)$ of water retained in the whole soil between $33 \mathrm{kPa}$ and $1500 \mathrm{kPa}$ tension, $\mathrm{W}_{33<2 \mathrm{~mm}}$ is the weight percentage of water retained at $33 \mathrm{kPa}$ on a $<2 \mathrm{~mm}$ soil basis, $\mathrm{W}_{1500<2 \mathrm{~mm}}$ is the weight percentage of water retained at $1500 \mathrm{kPa}$ on a $<2 \mathrm{~mm}$ soil basis, $\mathrm{Db}_{33<2 \mathrm{~mm}}$ is the bulk density at $33 \mathrm{kPa}$ water content on $\mathrm{a}<2 \mathrm{~mm}$ base, $\mathrm{P}_{\mathrm{w}}$ is the density of water and $\mathrm{Cm}$ is the coarse fragment material conversion factor $\left.=\left(100-\mathrm{Vol}_{>2 \mathrm{~mm}}\right) / 100\right)$ where $\mathrm{Vol}_{>2 \mathrm{~mm}}$ is the volume percentage of the $>2 \mathrm{~mm}$ fraction according to standard soil survey methods (Method 3D5a, Soil Survey Staff, 2004).

Texture of Hagerstown and Swanpond soil samples was determined using the standard soil survey pipet method (Method 3A1, Soil Survey Staff, 1996). Texture of Carbo soil samples was determined by a modified pipet method (Indorante et al., 1990). This method replaces the 1000-ml sedimentation cylinders with 500-ml fleakers. A limited number of samples of Hagerstown and Swanpond soils also were analyzed using 
Indorante's modified pipet method and compared to the standard soil survey pipet method to ensure comparability between the two methods. Organic matter was removed by digesting the samples with $3 \%$ hydrogen peroxide while the samples were heated to approximately $80^{\circ} \mathrm{C}$. Sand fractionation for all samples was determined by standard soil survey methods (Method 3A1, Soil Survey Staff, 1996).

Atterberg limits (liquid limit and plasticity index) were measured by ASTM method D4318 (American Society for Testing and Materials, 2000).

\section{Chemical Properties}

Soil reaction $(\mathrm{pH})$ was determined on a 1:1 soil to water suspension and a 1:2 soil to calcium chloride $\left(\mathrm{CaCl}_{2}\right)$ suspension (Method 8C1f, Soil Survey Staff, 1996).

Total carbon, nitrogen, and sulfur were determined by combustion using a LECO 2000 CNS analyzer for the Carbo soil samples. Total carbon, nitrogen and sulfur also were determined by combustion methods for the Hagerstown and Swanpond soil samples (Method 4H2a1, 4H2a2, 4H2a3, Soil Survey Staff, 2004).

Extractable acidity was determined by barium chloride-triethanolamine $\left(\mathrm{BaCl}_{2}-\right.$ TEA) buffered at pH 8.2 (Method 6H5a, Soil Survey Staff, 1996).

Extractable aluminum and manganese were determined on samples with a 1:1 water $\mathrm{pH}<5.5$ using the potassium chloride $(\mathrm{KCl})$ extraction procedure and extracts were analyzed on an atomic absorption spectrometer (AA) (Method 6G9c, 6D3b, Soil Survey Staff, 1996).

Extractable bases ( $\mathrm{Ca}, \mathrm{Mg}, \mathrm{Na}, \mathrm{K})$ were extracted by ammonium acetate $\left(\mathrm{NH}_{4} \mathrm{OAc}\right)$ buffered at $\mathrm{pH} 7.0$ (Method 4B1a1b1, 4B1a1b2, 4B1a1b3, 4B1a1b4, Soil Survey Staff, 2004). Sodium and K were determined by analyzing extracts on an atomic absorption spectrometer (AA). Calcium and $\mathrm{Mg}$ were determined by analyzing extracts on an inductively coupled plasma emission spectrometer (ICP).

Cation exchange capacity (CEC) was determined by the ammonium acetate method $\left(\mathrm{NH}_{4} \mathrm{OAc}\right.$ ) buffered at $\mathrm{pH} 7.0$ (Method 5A8b, Soil Survey Staff, 1996). The $\mathrm{CEC}$ by $\mathrm{NH}_{4} \mathrm{OAc}, \mathrm{pH} 7$ is commonly used and has become a standard reference to which other methods are compared (Soil Survey Staff, 1996). Cation exchange capacity also was calculated by summing the ammonium acetate $\left(\mathrm{NH}_{4} \mathrm{OAc}\right)$ bases $(\mathrm{Ca}, \mathrm{Mg}, \mathrm{Na}, \mathrm{K})$ 
plus the barium chloride-triethanolamine $\left(\mathrm{BaCl}_{2}-\mathrm{TEA}\right)$ extractable acidity (Method 5A3a, Soil Survey Staff, 1996).

Effective cation exchange capacity (ECEC) was calculated by summing the ammonium acetate $\left(\mathrm{NH}_{4} \mathrm{OAc}\right)$ bases plus the potassium chloride $(\mathrm{KCl})$ extractable aluminum (Method 5A3b, Soil Survey Staff, 1996).

Total elemental analysis was determined by a total soil digestion using nitric acid $\left(\mathrm{HNO}_{3}\right)$ and hydrofluoric acid (HF) (Method 4H1b, Soil Survey Staff, 2004).

\section{Mineralogy}

One or two B horizons were selected from each of the 10 pedons and sent to the National Soil Survey Laboratory for mineralogical analysis. Clay mineralogy was determined by x-ray diffraction (Method 7A2i, Soil Survey Staff, 1996).

\section{Statistical Analysis}

Statistical analysis was used to compare data among and between soils. Simple regression analyses were used to correlate relationships of selected physical and chemical soil properties. Analysis of variance (ANOVA) was used to analyze soil series and weighted averages of selected soil properties. Duncan's multiple range test was used to group similar soils.

\section{Soil Classification}

All soils were classified based on field descriptions and laboratory analyses using criteria described in Soil Taxonomy (Soil Survey Staff, 1999). 


\section{Results and Discussion}

\section{Field Observations of Slickensides and Cracking}

Complete field descriptions for all soils in this study can be found in Appendices A, B, and C. Ten pedons were described and sampled in June and July of 1999. All of the pedons formed in residual material from limestone. Swanpond \#2 and \#3 and the three Carbo pedons, formed on the Chambersburg Limestone geology. Swanpond \#1 and \#4 and the three Hagerstown pedons formed on the Beekmantown Limestone geology. The Swanpond \#3 pedon is the current Type Location for the Swanpond series. Clay movement in the form of clay films was observed in every pedon. Each of the soils was described in the field as having an argillic horizon. The Carbo and Swanpond pedons showed field evidence of shrink-swell either by the presence of slickensides or a combination of cracks and slickensides (Figure 2). The Hagerstown pedons, however,

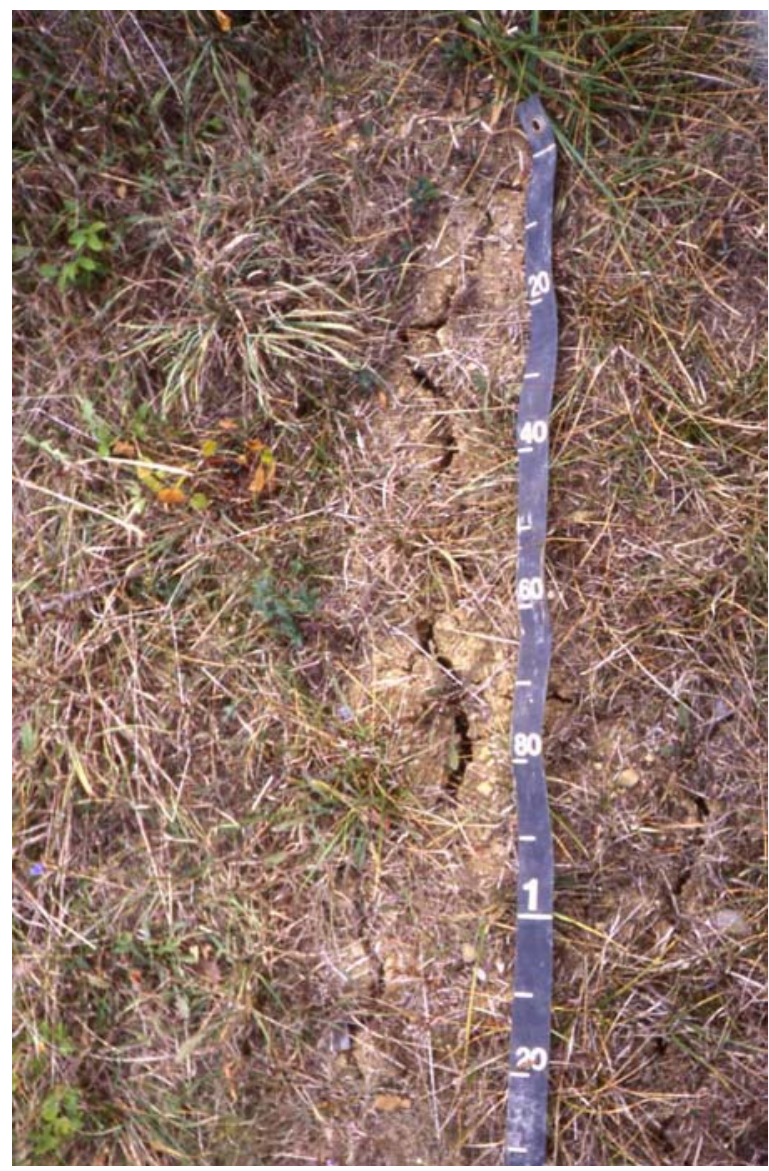

Figure 2. Surface cracking in Carbo soil in Berkeley County. 
did not indicate shrink-swell from any field observations. Geology and selected field observations described for each pedon are summarized in Table 1.

Table 1. Geology and selected field observations of each pedon.

\begin{tabular}{|c|c|c|c|c|c|c|}
\hline Pedon & Geology & $\begin{array}{c}\text { Maximum } \\
\text { Width of } \\
\text { Cracks } \\
(\mathrm{mm})\end{array}$ & $\begin{array}{l}\text { Width } \\
\text { Between } \\
\text { Cracks } \\
\text { (cm) }\end{array}$ & $\begin{array}{l}\text { Thickness } \\
\text { of Btss } \\
\text { Horizon } \\
\text { (cm) }\end{array}$ & $\begin{array}{l}\text { Maximum } \\
\text { Size of } \\
\text { Slickensides } \\
\text { (cm) }\end{array}$ & $\begin{array}{l}\text { Presence of } \\
\text { Intersecting } \\
\text { Slickensides }\end{array}$ \\
\hline Carbo \#1 & Chambersburg & 20 & $13-33$ & 35 & 20 & Yes \\
\hline Carbo \#2 & Chambersburg & 15 & $20-40$ & 51 & 30 & Yes \\
\hline Carbo \#3 & Chambersburg & -- & -- & 18 & 20 & No \\
\hline Swanpond \#1 & Beekmantown & -- & -- & $95+$ & 30 & No \\
\hline Swanpond \#2 & Chambersburg & -- & -- & 104 & 20 & No \\
\hline Swanpond \#3 & Chambersburg & 8 & $15-20$ & $96+$ & 19 & Yes \\
\hline Swanpond \#4 & Beekmantown & 3 & $18-36$ & 87 & 15 & No \\
\hline Hagerstown \#1 & Beekmantown & -- & -- & -- & -- & -- \\
\hline Hagerstown \#2 & Beekmantown & -- & -- & -- & -- & -- \\
\hline Hagerstown \#3 & Beekmantown & -- & -- & -- & -- & -- \\
\hline
\end{tabular}

Carbo \#1 and \#2 pedons had cracking that began at the surface and extended to bedrock (Figure 3). Cracks in the Carbo \#1 pedon ranged from 2 to $5 \mathrm{~mm}$ in width and occurred 13 to $33 \mathrm{~cm}$ apart across the profile. The cracks appeared widest in the Ap and Bt horizons and narrowed in the Btss horizons. One crack in the Ap2 horizon measured 2 $\mathrm{cm}$ in width. Cracks were coated with A horizon material from top to bottom. Cracks in the Carbo \#2 pedon ranged in width from $2 \mathrm{~mm}$ to $1.5 \mathrm{~cm}$ and occurred 20 to $40 \mathrm{~cm}$ apart across the profile. No cracking was observed in the Carbo \#3 pedon. Swanpond \#1 and \#2 pedons did not exhibit any cracking. The Swanpond \#3 pedon had cracking which began at the bottom of the Ap2 horizon and extended into the Btss 4 horizon. These cracks varied in width from 1 to $8 \mathrm{~mm}$ and occurred 15 to $20 \mathrm{~cm}$ apart across the profile. Cracking in Swanpond \#4 pedon began at the bottom of the Ap horizon and extended to the bottom of the Bt horizon. Cracks varied in width from 1 to $3 \mathrm{~mm}$ and occurred 18 to $36 \mathrm{~cm}$ apart across the profile. 


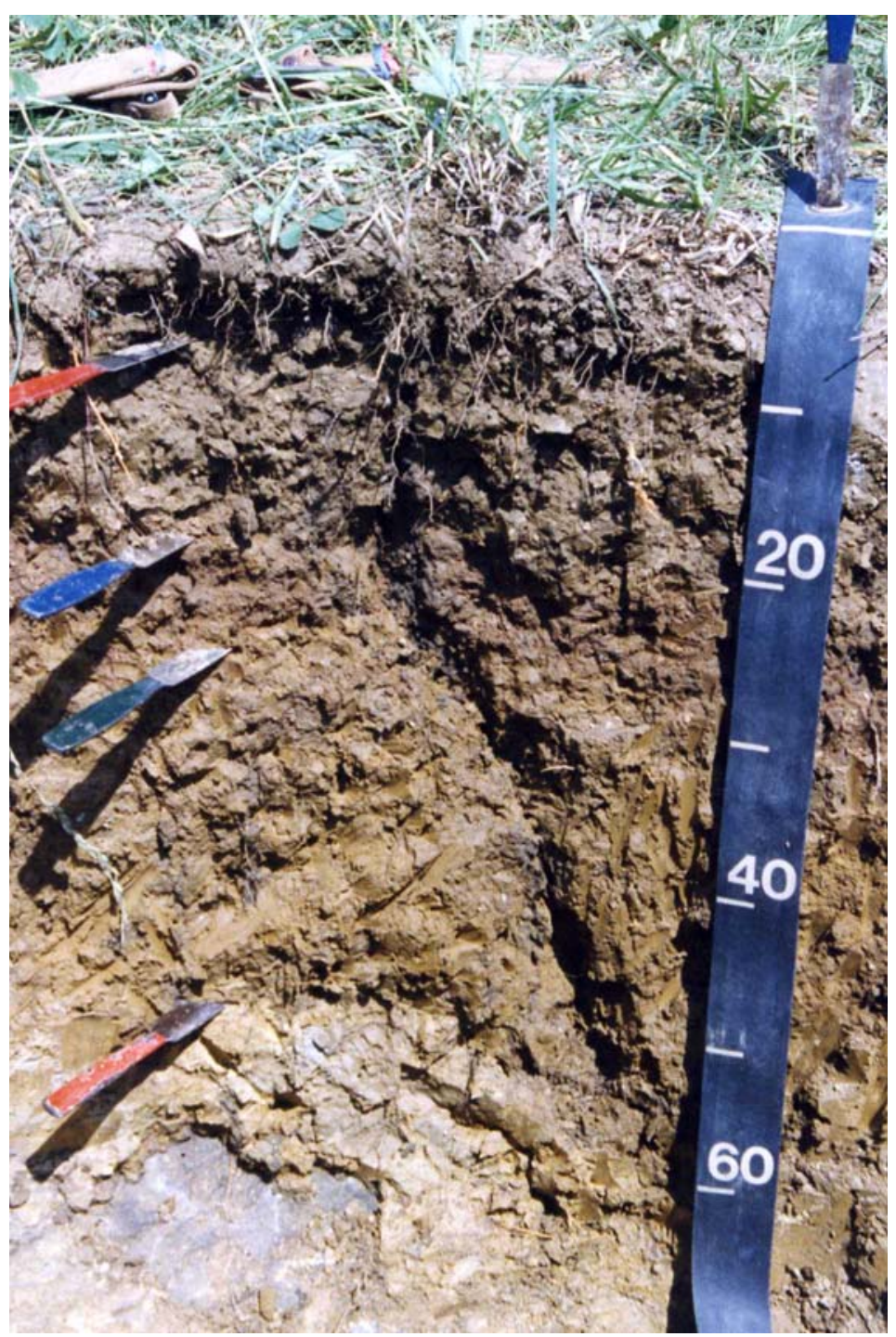

Figure 3. A large crack extending from the surface to bedrock in the Carbo \#1 pedon.

Two Btss horizons were described in the Carbo \#1 pedon for a combined thickness of $35 \mathrm{~cm}$. Slickensides ranged from 5 to $20 \mathrm{~cm}$ in size and were noted as intersecting near the base of the Btss1 horizon. These intersecting slickensides were tilted at 25 to 45 degrees from the horizontal. The Carbo \#2 pedon also was described as having two Btss horizons, which combined for a thickness of $51 \mathrm{~cm}$. Size of the slickensides in the Carbo \#2 pedon varied from 5 to $30+\mathrm{cm}$ (Figure 4). Intersecting slickensides were noted during sampling of the Btss1 horizon. One Btss horizon having a thickness of $18 \mathrm{~cm}$ was described in the Carbo \#3 pedon. The Carbo \#3 pedon 


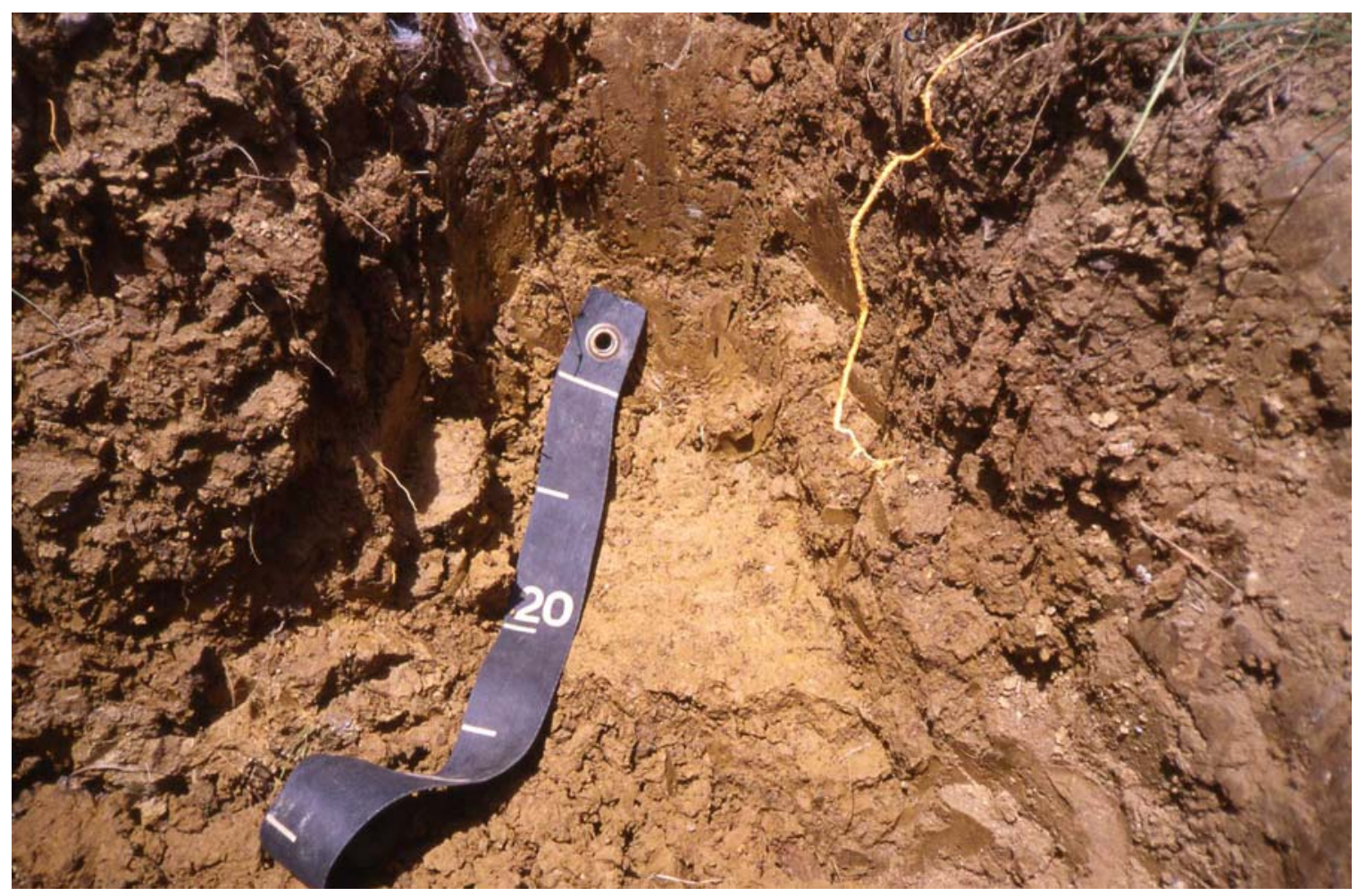

Figure 4. A large slickenside in the Carbo \#2 pedon.

slickensides ranged in size from 2 to $20 \mathrm{~cm}$. Slickensides (Btss horizons) also were described in Carbo soils in the central and southern part of the Great Valley in Virginia by Thomas (1998). Two Btss horizons were described in the Swanpond \#1 pedon for a combined thickness of $95+\mathrm{cm}$. Small slickensides ranging from 1 to $5 \mathrm{~cm}$ in size were described, but upon sampling larger slickensides up to $10 \times 20 \mathrm{~cm}$ and $15 \times 30 \mathrm{~cm}$ in size were found in the Btss 1 and Btss2 horizons, respectively. Three Btss horizons were described in the Swanpond \#2 pedon for a combined thickness of $104 \mathrm{~cm}$. Again, small slickensides ranging from 2 to $5 \mathrm{~cm}$ in size were described, but upon sampling a large slickenside measuring $10 \times 20 \mathrm{~cm}$ was found at the bottom of the Btss1 and top of the Btss2 horizons. Four Btss horizons were described in the Swanpond \#3 pedon for a combined thickness of $96+\mathrm{cm}$. Slickensides ranged in size from 2.5 to $19 \mathrm{~cm}$. Intersecting slickensides (Figure 5) were noted in each of the four Btss horizons. Intersecting slickensides in the Btss 2 were tilted at 15 to 35 degrees from the horizontal and intersecting slickensides in the Btss 3 horizon were tilted at 30 degrees from the horizontal. The Swanpond \#4 pedon was described as having three Btss horizons 
combining for a thickness of $87 \mathrm{~cm}$. The Swanpond \#4 pedon slickensides ranged in size from 1.5 to $15 \mathrm{~cm}$.

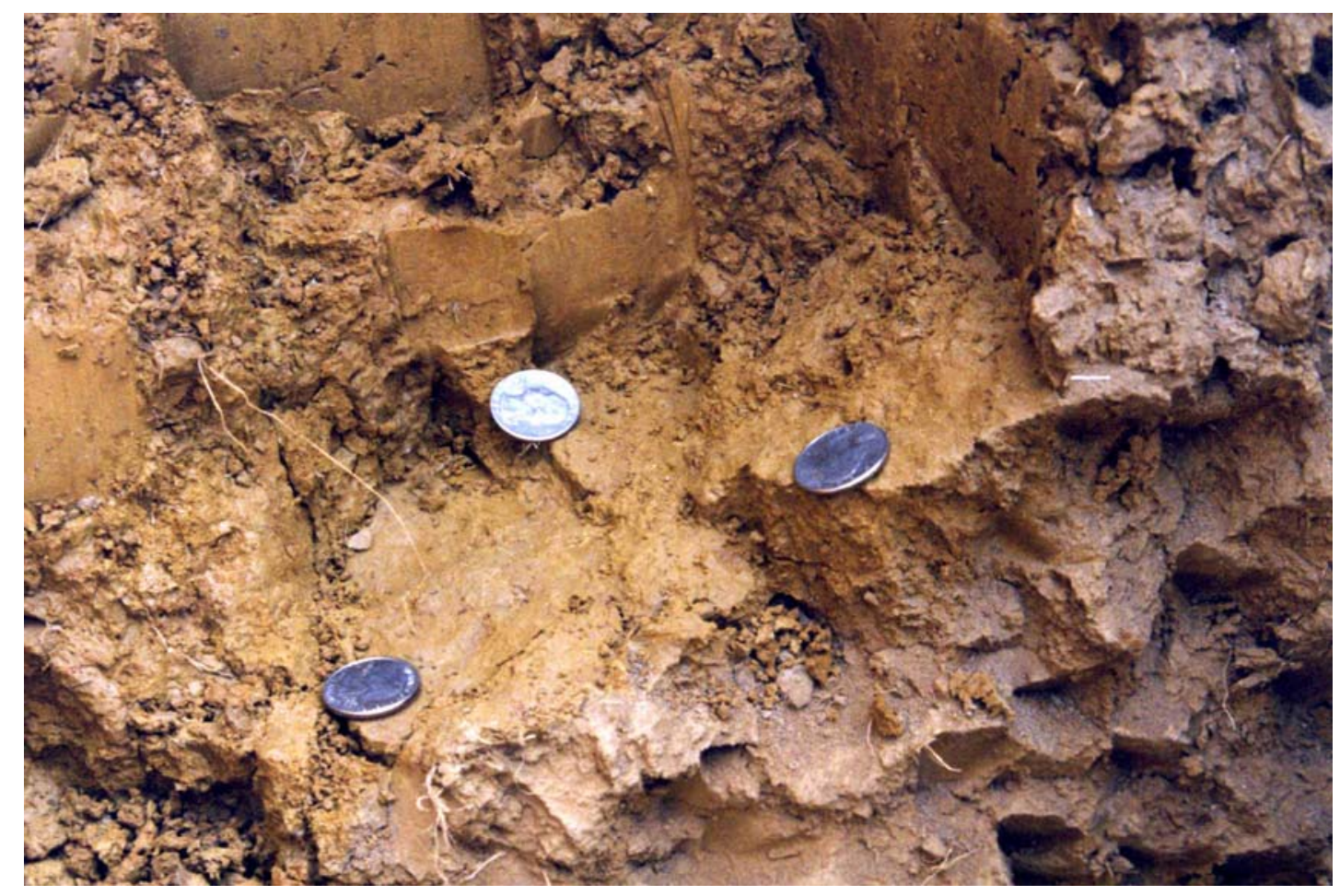

Figure 5. Intersecting slickensides in the Swanpond \#3 pedon. Quarters are used to show the angle and size of the slickensides.

It should be noted that during the excavation and sampling of these pedons, it was apparent that there were larger slickensides present than those initially described. However, due to the size and mass of the slickensides it was not possible to describe them without destroying or breaking these slickensides into smaller pieces during excavation; therefore it can not be determined exactly how large some of these slickensides were in these soils.

At the onset of this research it was thought that soils occurring on the Chambersburg Limestone were more likely to have shrink-swell potential than soils forming on the Beekmantown Limestone based on field experiences of soil scientists in the area. That, however, does not appear to be the case as soils with shrink-swell characteristics were found on both the Chambersburg and Beekmantown limestones. Since the inception of this research study, soils with high shrink-swell potential have 
been mapped on both geologies in the surrounding area. Geology may still be a factor in the shrink-swell of these soils as the formations overlap in lithologies, however, no geologic control can be determined at the formation level.

\section{Laboratory Analyses}

Complete physical, chemical, and mineralogy data for all pedons can be found in Appendices A, B and C. Similar results were found by Thomas (1998) in central and southern Virginia and Cronce (1988) in central Pennsylvania.

Box and whisker plots are used to display data distributions for soil horizon physical and chemical properties in Figures $6-20$. The box represents the interquartile range (IQ) that contains 50 percent of the values. The whiskers are lines that extend from the box to the lowest and highest values, excluding outliers. Outliers that fall between 1.5 and 3 IQ ranges from the median are represented by asterisk markers, while outliers that fall beyond 3 IQ ranges from the median are represented by circular markers. A line across the box indicates the median and the mean or average is represented by a diamond marker. The first letter in the horizon designation for Figures $6-20$ represent the soil series where: $\mathrm{S}=$ Swanpond; $\mathrm{C}=\mathrm{Carbo}$; and $\mathrm{H}=$ Hagerstown. Table 2 displays the number of observations and the standard deviations for soil properties and horizons displayed in Figures $6-20$.

\section{Physical Properties}

\section{Bulk Density}

Soil bulk density refers to the ratio of the mass of solids to the total volume. Total volume includes the volume of both solids and pore space. Bulk density is highly dependent upon soil moisture conditions at the time of sampling. Bulk density values can change based upon changes in the soil volume (shrinking and swelling), due to changes in the soil water content (Soil Survey Staff, 2004).

Bulk density was determined using two methods, $33 \mathrm{kPa}$ (1/3 bar) desorption and oven-dry. These two methods were used in order to determine coefficient of linear extensibility and water retention difference. 
Table 2. Number of observations (shown in parentheses) and standard deviation of soil horizon properties displayed in Figures 2 - 16.

\begin{tabular}{|c|c|c|c|c|c|c|c|c|c|c|}
\hline & \multirow[b]{2}{*}{ Swanpond } & \multicolumn{2}{|l|}{ A Horizon } & \multicolumn{2}{|l|}{ E Horizon } & \multicolumn{2}{|l|}{ Bt Horizon } & \multicolumn{2}{|c|}{ Btss Horizon } & \multirow{2}{*}{$\begin{array}{l}\text { C Horizon } \\
\text { Hagerstown }\end{array}$} \\
\hline & & $\underline{\text { Carbo }}$ & $\underline{\text { Hagerstown }}$ & Hagerstown & Swanpond & $\underline{\text { Carbo }}$ & Hagerstown & Swanpond & $\underline{\text { Carbo }}$ & \\
\hline 33 kPa Bulk Density & (6) 0.07 & (5) 0.16 & (2) 0.06 & --- & (5) 0.10 & (3) 0.04 & (8) 0.08 & (12) 0.08 & (5) 0.08 & (1) -- \\
\hline Oven-Dry Bulk Density & (6) 0.08 & (5) 0.16 & (2) 0.05 & -- -- & (4) 0.05 & (3) 0.02 & (8) 0.09 & (8) 0.09 & (5) 0.07 & (1) -- \\
\hline COLE & (6) 0.01 & (5) 0.01 & (2) 0.01 & --- & (5) 0.02 & (3) 0.01 & (8) 0.01 & (12) 0.01 & (5) 0.01 & (1) -- \\
\hline Clay & (6) 5.5 & (5) 4.6 & (3) 2.2 & (1) -- & (5) 21.5 & (3) 2.1 & (9) 10.9 & (12) 8.1 & (5) 5.4 & (1) -- \\
\hline $33 \mathrm{kPa}$ Moisture Retention & (6) 2.0 & (5) 4.5 & (3) 5.9 & (1) -- & (5) 7.4 & (3) 1.9 & (9) 5.6 & (12) 4.4 & (5) 2.3 & (1) -- \\
\hline 1500 kPa Moisture Retention & (6) 2.4 & (5) 1.7 & (3) 0.5 & (1) -- & (5) 8.3 & (3) 0.2 & (9) 4.0 & (12) 2.9 & (5) 1.7 & (1) -- \\
\hline Water Retention Difference & (6) 0.04 & (5) 0.03 & (2) 0.03 & -- -- & (5) 0.06 & (3) 0.03 & (8) 0.03 & (12) 0.04 & (5) 0.01 & (1) -- \\
\hline Liquid Limit & (6) 6 & (5) 9 & (3) 9 & (1) -- & (5) 20 & (3) 4 & (9) 10 & (12) 10 & (5) 2 & (1) -- \\
\hline Plasticity Index & (6) 3 & (5) 5 & (3) 5 & (1) -- & (5) 16 & (3) 4 & (9) 8 & (12) 8 & (5) 2 & (1) -- \\
\hline pH (1:1 Water) & (6) 0.5 & (5) 0.4 & (3) 0.2 & (1) -- & (5) 0.6 & (3) 0.4 & (9) 0.6 & (12) 0.8 & (5) 0.3 & (1) -- \\
\hline pH (1:2 Calcium Chloride) & (6) 0.3 & (5) 0.3 & (3) 0.4 & (1) -- & (5) 0.6 & (3) 0.2 & (9) 0.6 & (12) 1.0 & (5) 0.3 & (1) -- \\
\hline Extractable Acidity & (6) 2.4 & (5) 1.5 & (3) 1.7 & (1) -- & (5) 4.6 & (3) 1.9 & (9) 3.2 & (12) 4.8 & (5) 2.0 & (1) -- \\
\hline Sum of Bases & (6) 5.8 & (5) 3.3 & (3) 4.0 & (1) -- & (5) 6.1 & (3) 1.3 & (9) 2.6 & (12) 3.7 & (5) 8.6 & (1) -- \\
\hline CEC-7 & (6) 2.7 & (5) 2.9 & (3) 2.9 & (1) -- & (5) 8.3 & (3) 1.4 & (9) 2.1 & (12) 3.3 & (5) 3.8 & (1) -- \\
\hline CEC-8.2 & (6) 5.2 & (5) 3.8 & (3) 3.0 & (1) -- & (5) 10.1 & (3) 0.6 & (9) 2.6 & (12) 3.6 & (5) 7.5 & (1) -- \\
\hline
\end{tabular}


Average $33 \mathrm{kPa}$ desorption bulk density in the Swanpond and Carbo soils showed an initial increase then a decrease with depth (Figure 6). Swanpond and Carbo soils had the highest average $33 \mathrm{kPa}$ desorption bulk density which occurred in the Bt horizon $\left(1.59 \mathrm{~g} / \mathrm{cm}^{3}\right.$ and $1.60 \mathrm{~g} / \mathrm{cm}^{3}$, respectively). Average $33 \mathrm{kPa}$ desorption bulk density values occurring in the A and Bt horizons of the Hagerstown soil were identical (1.52 $\mathrm{g} / \mathrm{cm}^{3}$ ). The lowest average $33 \mathrm{kPa}$ desorption bulk density was reported in the Hagerstown C horizon $\left(1.35 \mathrm{~g} / \mathrm{cm}^{3}\right)$.

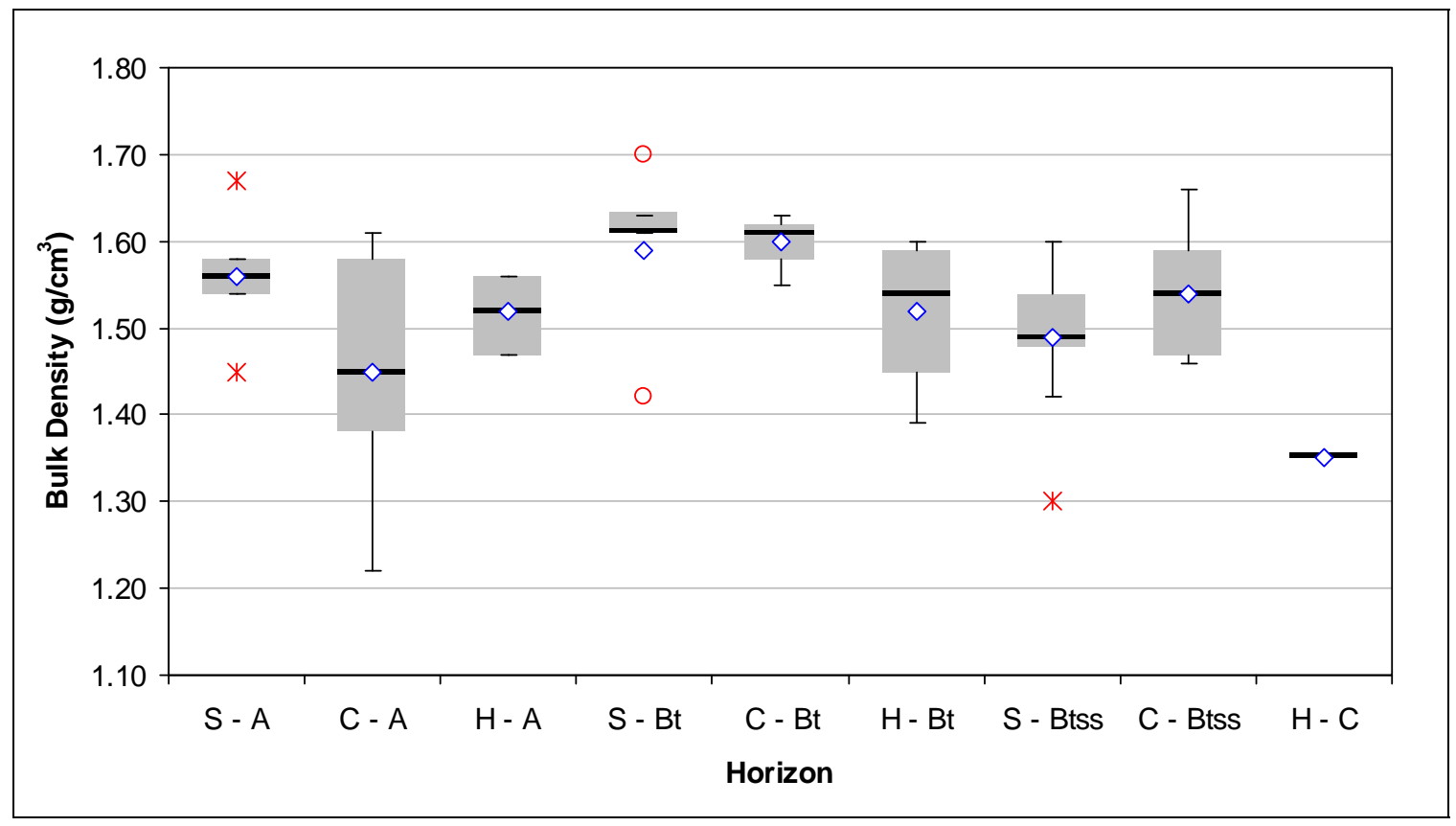

Figure 6. Distribution of $33 \mathrm{kPa}$ bulk density values for clayey soils.

Average oven-dry bulk density in all soils showed an initial increase then a decrease with depth (Figure 7). Highest average oven-dry bulk density values occurred in the Bt horizons of all soils. The highest average oven-dry bulk density value occurred in the Carbo Bt horizon $\left(1.81 \mathrm{~g} / \mathrm{cm}^{3}\right)$. The lowest average oven-dry bulk density occurred in the Hagerstown $\mathrm{C}$ horizon $\left(1.40 \mathrm{~g} / \mathrm{cm}^{3}\right)$.

Average oven-dry bulk density values were higher than average $33 \mathrm{kPa}$ desorption bulk density values in all soils (Figures 6 \& 7). Soil Survey Staff (1995) reports that oven-dry bulk density and $33 \mathrm{kPa}$ bulk density may be similar in sandy soils, but the oven-dry bulk density is greater than $33 \mathrm{kPa}$ bulk density in smectitic soils. 


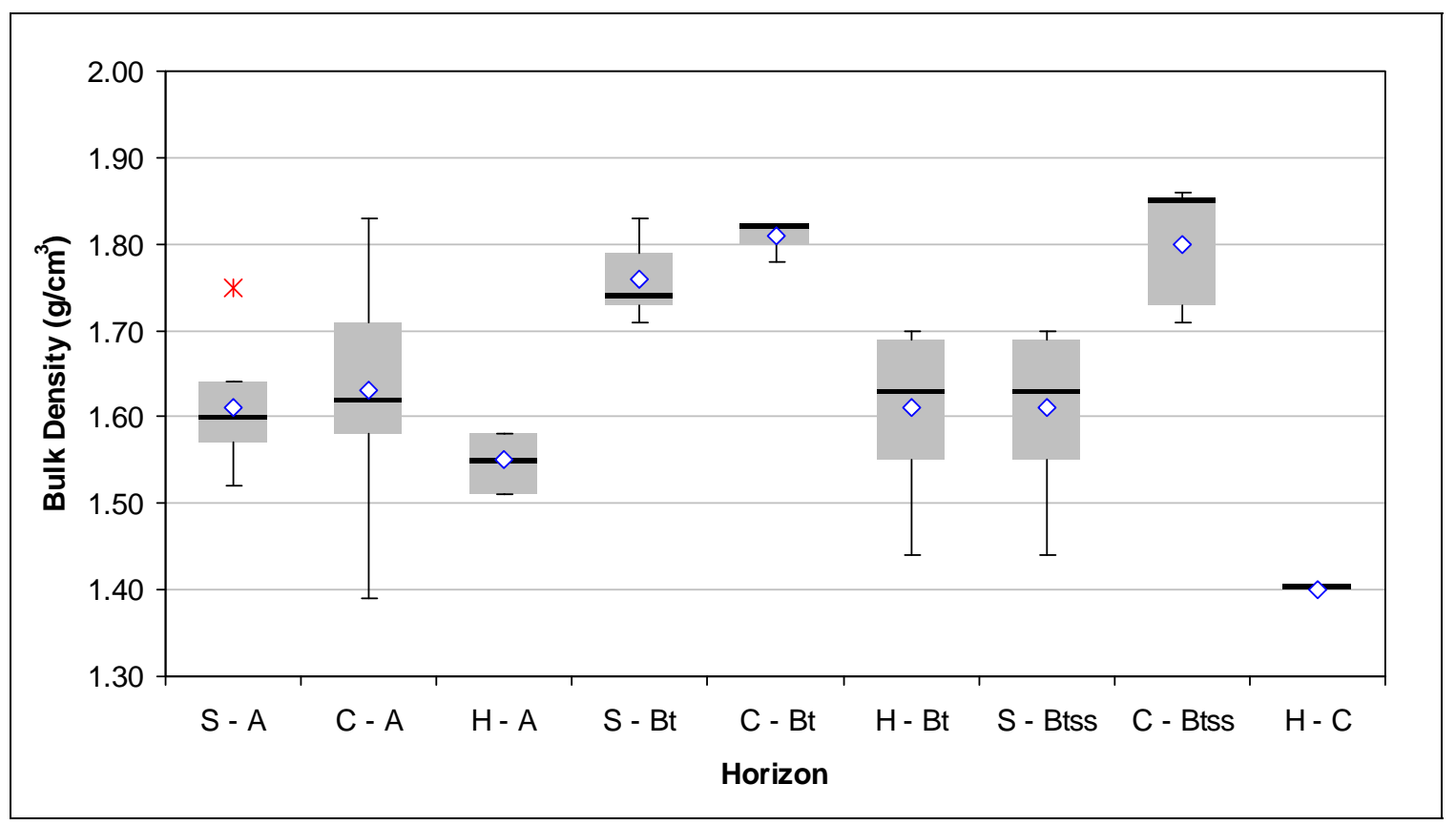

Figure 7. Distribution of oven-dry bulk density values for clayey soils.

\section{COLE}

Coefficient of linear extensibility is a direct measurement of shrink-swell potential. Shrink-swell potential is an important factor which affects physical qualities of the soil surface (large, deep cracks in dry seasons), as well as soil genetic processes, and soil classification (Buol et al., 1997). COLE, which developed as an application of bulk density data, is a derived value that measures the fractional change in the soil clod dimension from a moist state $(33 \mathrm{kPa})$ to a dry state (oven-dry) (Franzmeier and Ross, 1968; Grossman et al., 1968; Holmgren, 1968).

COLE generally increased with depth in the solum (Figure 8). Maximum expression of COLE occurred in the Btss horizon of the Swanpond and Carbo soils and in the Bt horizon of the Hagerstown soil. The highest average COLE (0.06) occurred in the Btss horizon of the Carbo and Swanpond soils. The lowest average COLE (0.01) occurred in the A horizon of the Hagerstown soil. The highest COLE value (0.09) occurred in the Btss2 horizon of the Swanpond \#1 pedon. Highest COLE value (0.08) in the Carbo pedons and (0.04) in the Hagerstown pedons occurred in the Btss 1 horizon of the Carbo \#1 pedon and the Bt2 horizon of the Hagerstown \#3 pedon, respectively. The lowest COLE value (0.00) occurred in the Ap horizon of the Hagerstown \#1 pedon. 
According to Soil Survey Staff (2007), if COLE exceeds 0.09, shrink-swell potential is rated very high; if COLE ranges from 0.09 to 0.06 , shrink-swell potential is rated high; if COLE ranges between 0.06 and 0.03 , shrink-swell potential is rated moderate; and if COLE does not exceed 0.03, shrink-swell potential is rated low.

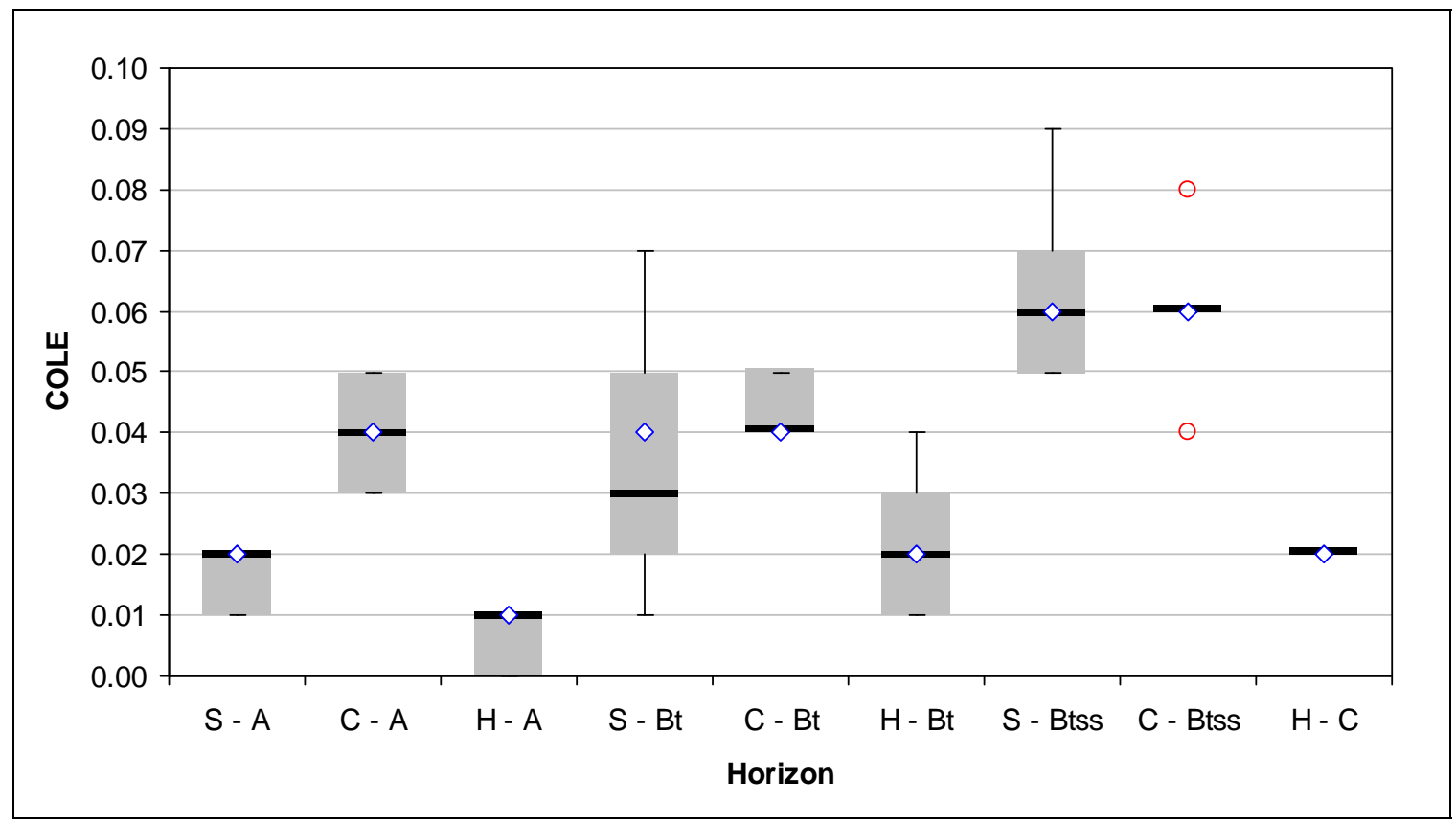

Figure 8. Distribution of COLE values for clayey soils.

\section{Clay Content}

Clay content generally increased with depth in the Swanpond and Carbo soils (Figure 9). Clay content increased from the A horizon to the B horizon in all pedons. Clay decreased from the A horizon to the E horizon and from the Bt horizon to $\mathrm{C}$ horizon in Hagerstown soil. Maximum average clay percentage occurred in the Btss horizon of the Swanpond and Carbo soils (73.4\% and 64.7\%, respectively) and in the Bt horizon of the Hagerstown soil $(51.0 \%)$. This can be attributed to translocation of clay from the surface and weathering of limestone parent material in the $\mathrm{BC}, \mathrm{C}$, and $\mathrm{R}$ horizons. Textures in the Bt horizons of the Hagerstown pedons were predominately clay but included clay loam and silty clay. Textures in all Btss horizons of the Swanpond and Carbo pedons were clay. The highest clay value (85.6 \%) occurred in the Btss 2 horizon of the Swanpond \#4 pedon. 


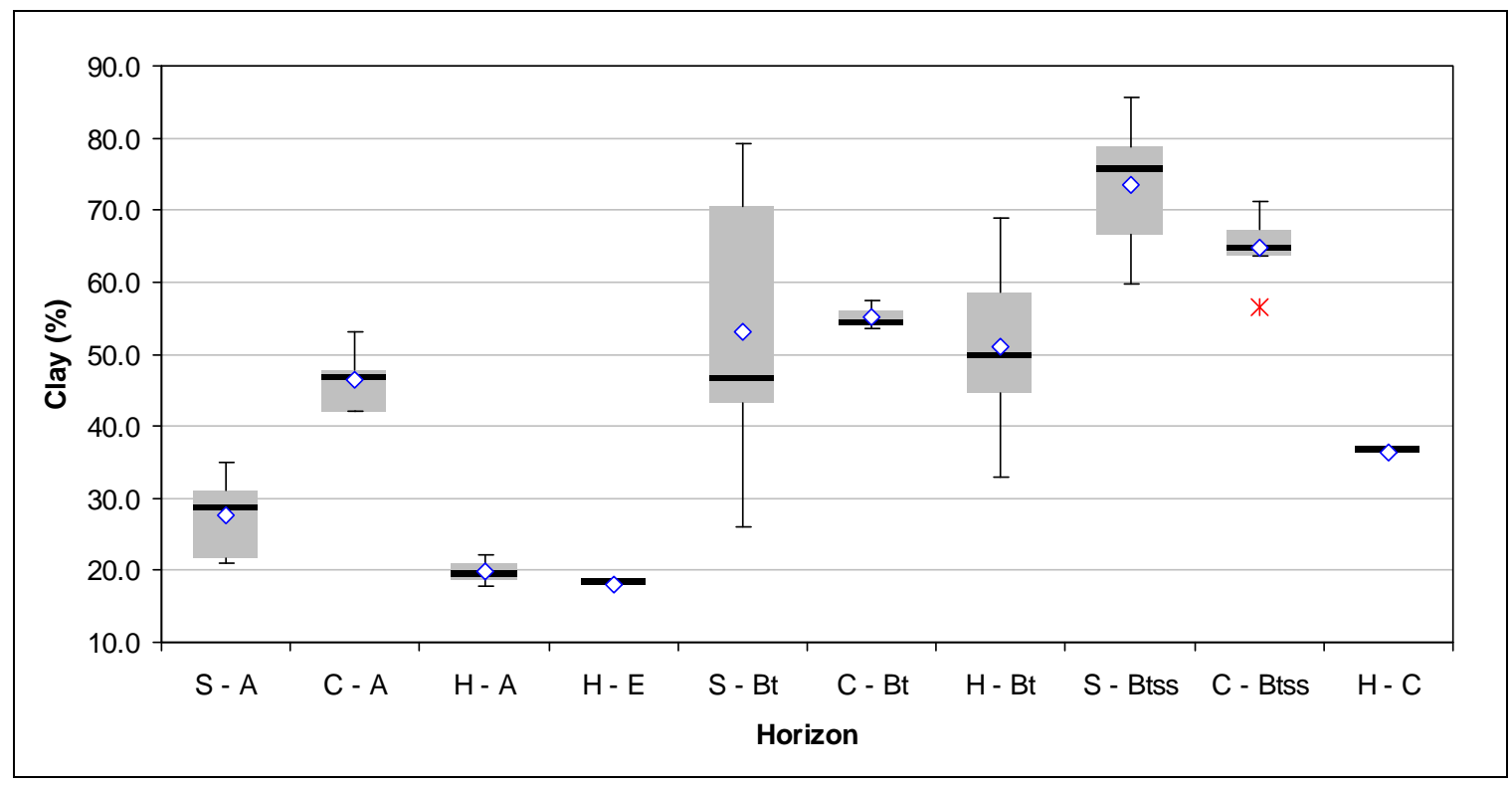

Figure 9. Distribution of clay content for clayey soils.

\section{Water Retention}

Water retention is defined as the soil water content at a given soil water suction. Water retention is dependent on particle-size distribution, clay mineralogy, organic matter, and structure or physical arrangement of the particles (Soil Survey Staff, 2004).

Moisture retention was determined at two pressures, $33 \mathrm{kPa}(1 / 3 \mathrm{bar})$ and 1500 $\mathrm{kPa}$ (15 bar). Average moisture retention values were highest in the Bt and Btss horizons in all soils (Figures $10 \& 11$ ). This was expected since the maximum amount of clay occurred in those horizons. High water retention values in the surface horizon at the 33 $\mathrm{kPa}$ pressure can be explained by the presence of organic matter. At $1500 \mathrm{kPa}$ pressure, the organic matter lost its ability to hold water, thus horizons with higher clay percentages retained more water. The highest average moisture retention at both the 33 $\mathrm{kPa}$ and $1500 \mathrm{kPa}$ pressures (40.2 \% and $27.0 \%$, respectively) occurred in the Swanpond Btss horizon. The lowest average moisture retention at $33 \mathrm{kPa}$ occurred in the Swanpond A horizon (28.7\%). The lowest average moisture retention at $1500 \mathrm{kPa}$ occurred in the Hagerstown E horizon (6.8\%). 


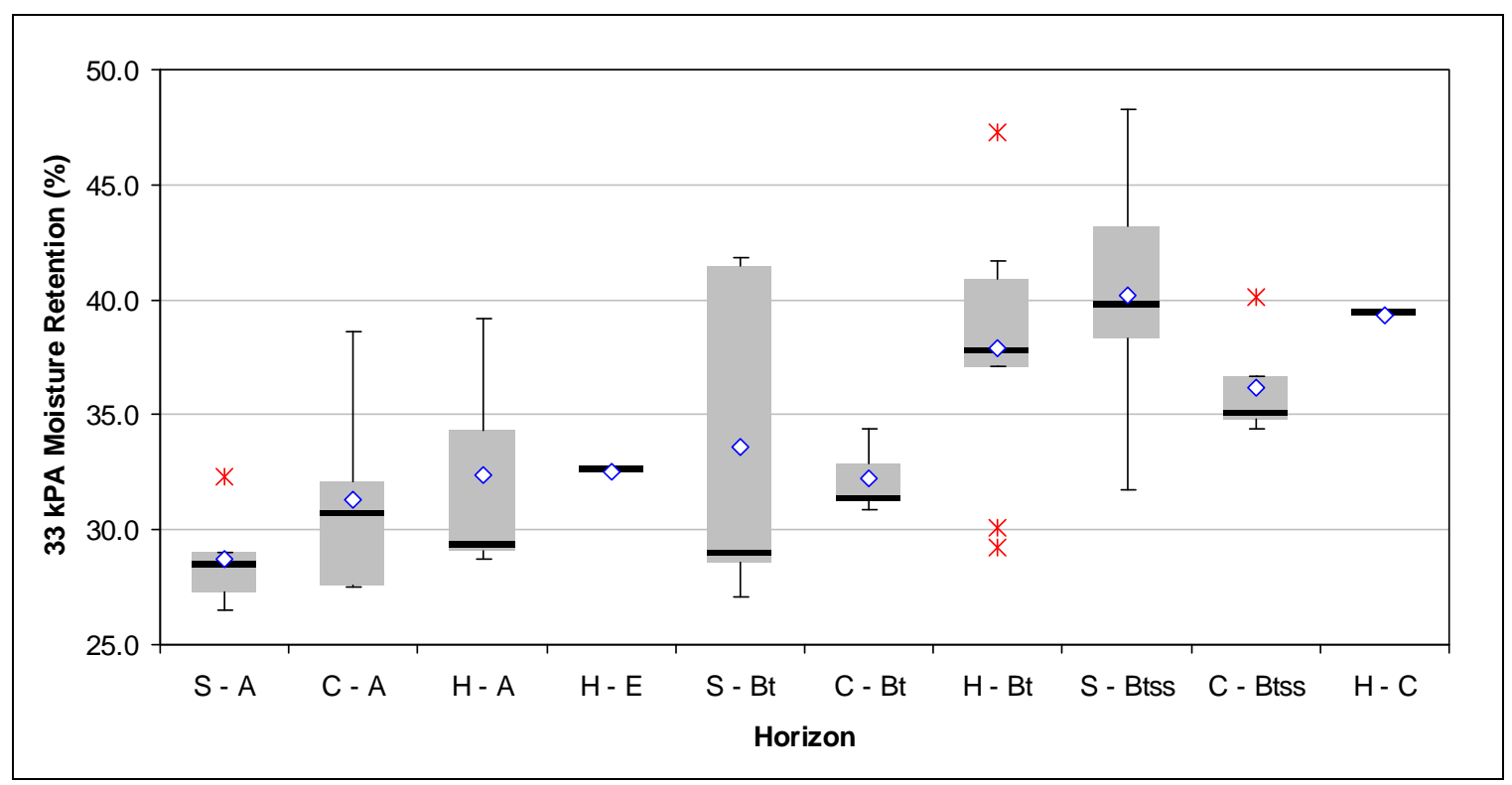

Figure 10. Distribution of $33 \mathrm{kPa}$ moisture retention percentages for clayey soils.

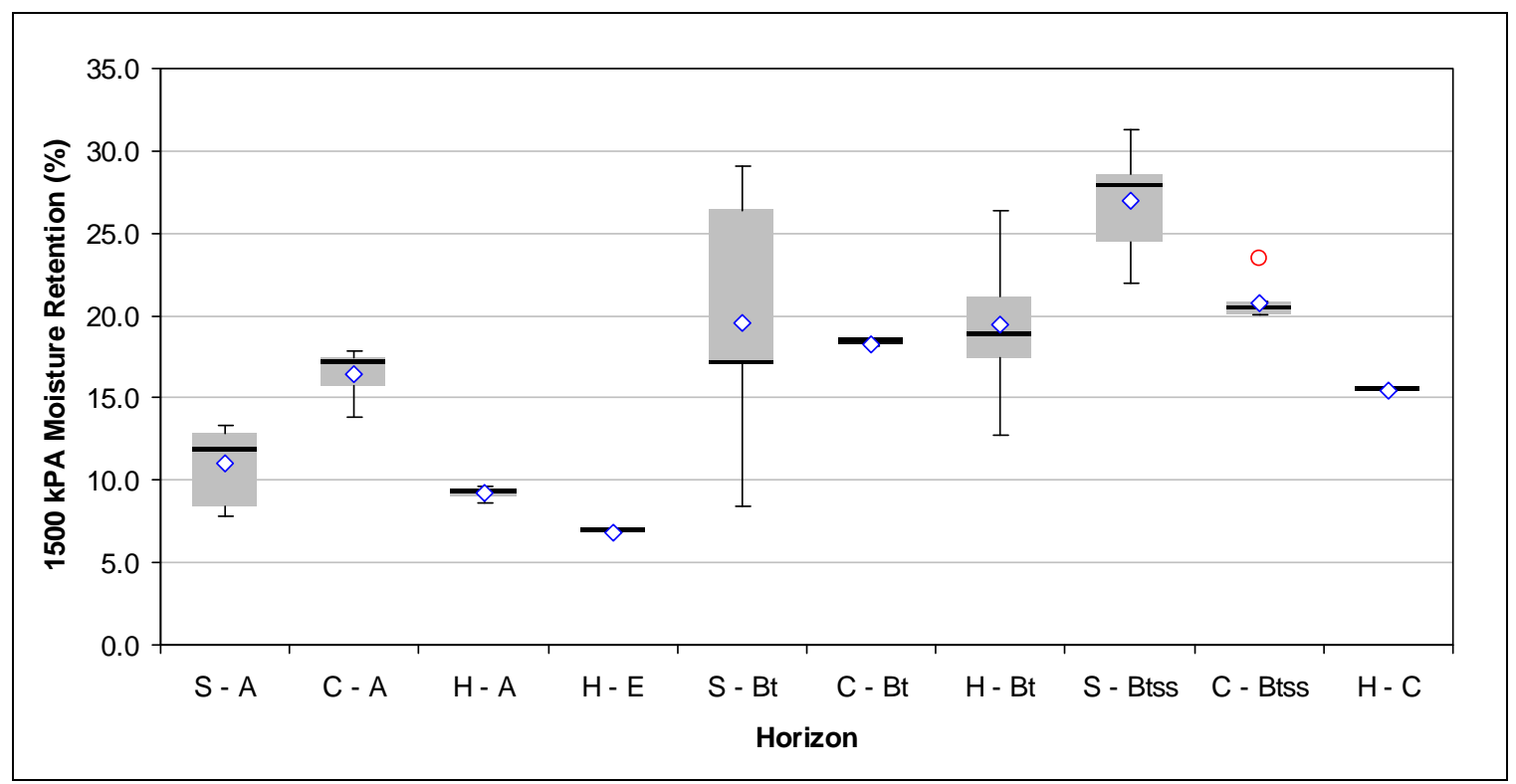

Figure 11. Distribution of $1500 \mathrm{kPa}$ moisture retention percentages for clayey soils.

Water retention difference is defined by Soil Survey Staff (2004) as the calculated value that denotes the volume fraction for water in the whole soil that is retained between $1500 \mathrm{kPa}$ suction and an upper limit of usually 33 or $10 \mathrm{kPa}$ suction. 
Water retention difference appeared as high or higher in some cases in the surface horizons (A) than the Bt and Btss horizons (Figure 12). This may seem surprising considering the large amount of clay difference between the surface horizons and the $\mathrm{Bt}$ and Btss horizons in some of the soils, but the difference may be explained by higher amounts of organic matter in the surface horizons than in the subsoils.

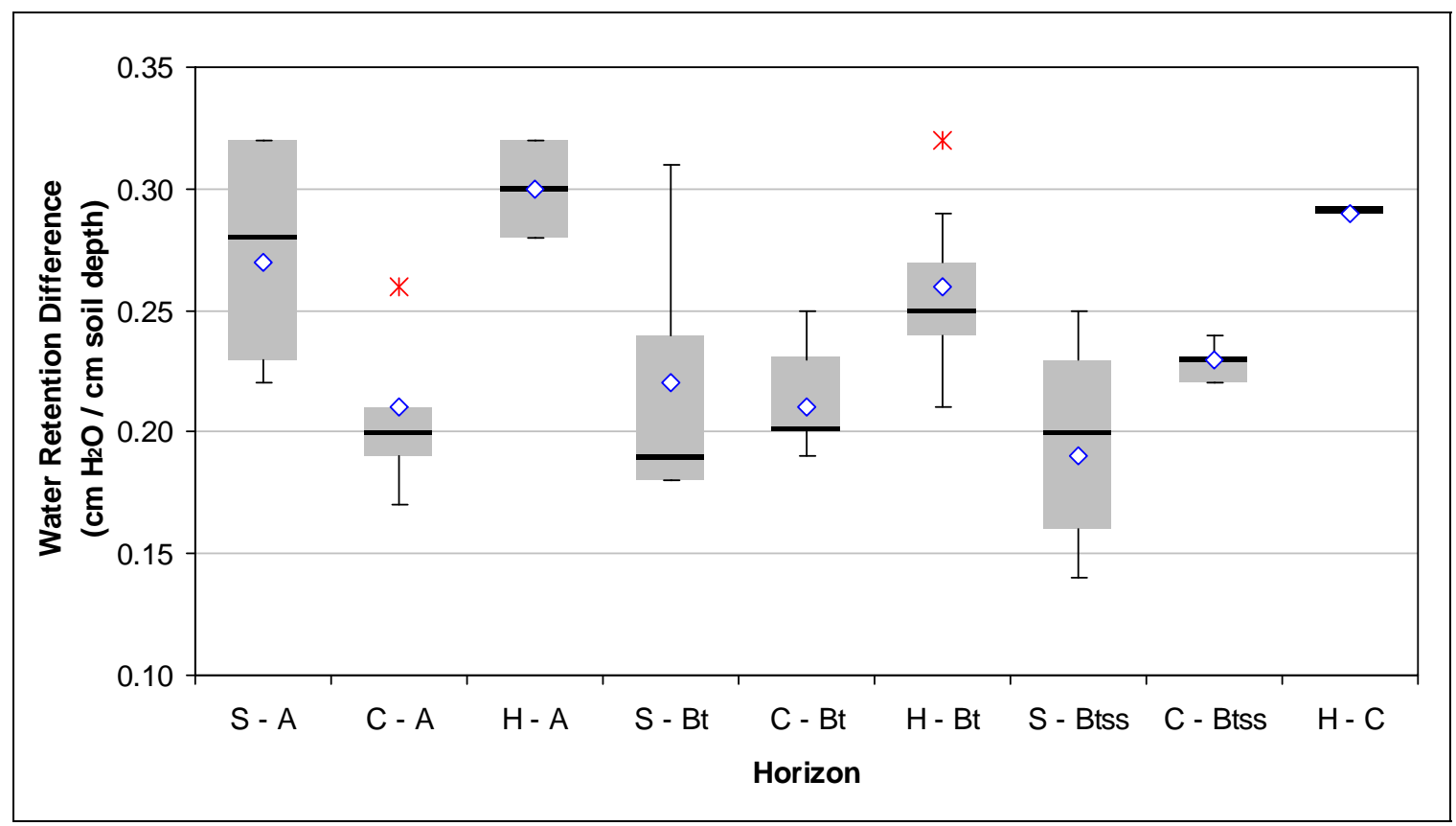

Figure 12. Distribution of water retention difference values for clayey soils.

\section{Atterberg Limits}

\section{Liquid Limit}

American Society for Testing and Materials (2000) defines liquid limit as the percent water content of a soil at the arbitrarily defined boundary between the semi-liquid and plastic states. American Society for Testing and Materials (2000) method D 4318 defines the liquid limit water content as the water content at which a pat of soil placed in a standard brass cup and cut by a groove of standard dimensions will flow together at the bottom of the groove for a distance of $13 \mathrm{~mm}$ (1/2 inch) when subjected to 25-35 shocks from the cup being dropped $10 \mathrm{~mm}$ in a standard liquid limit device operated at a rate of 2 shocks per second. 
Liquid limit values were generally highest in the Bt and Btss horizons in all soils, except for in the Carbo soil where values in the surface horizon were similar to $\mathrm{Bt}$ and Btss horizons (Figure 13). Organic matter may be playing a role in the elevated values in the surface horizon. Odell et al. (1960) found that liquid limit was strongly correlated to organic carbon in montmorillonitic and illitic dominated material. Gill and Reaves (1957) indicated that organic matter content influenced Atterberg limits. The highest average liquid limit occurred in the Swanpond Btss horizon (71). The lowest average liquid limit occurred in the Hagerstown E horizon (32).

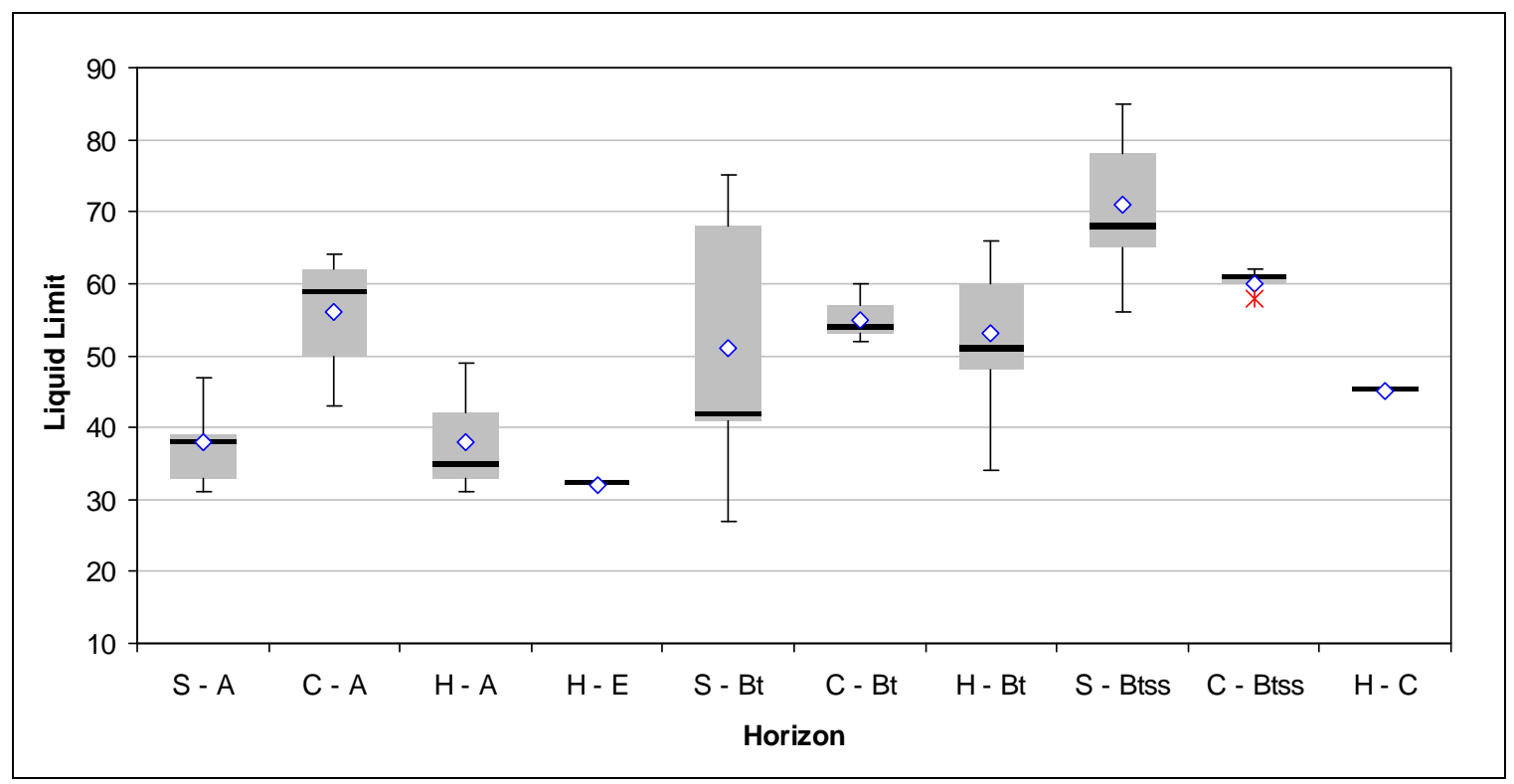

Figure 13. Distribution of liquid limit values for clayey soils.

\section{Plasticity Index}

Plasticity index, as defined by the American Society for Testing and Materials (2000), is the range of water content over which a soil behaves plastically. Numerically, the plasticity index is the difference between the liquid limit and the plastic limit.

Plasticity index is consistently higher in the Bt and Btss horizons than other horizons in all soils (Figure 14). The highest average plasticity index values occurred in the Swanpond Btss horizon (49). As expected, the lowest average plasticity index values occurred in the Hagerstown E horizon (11). 


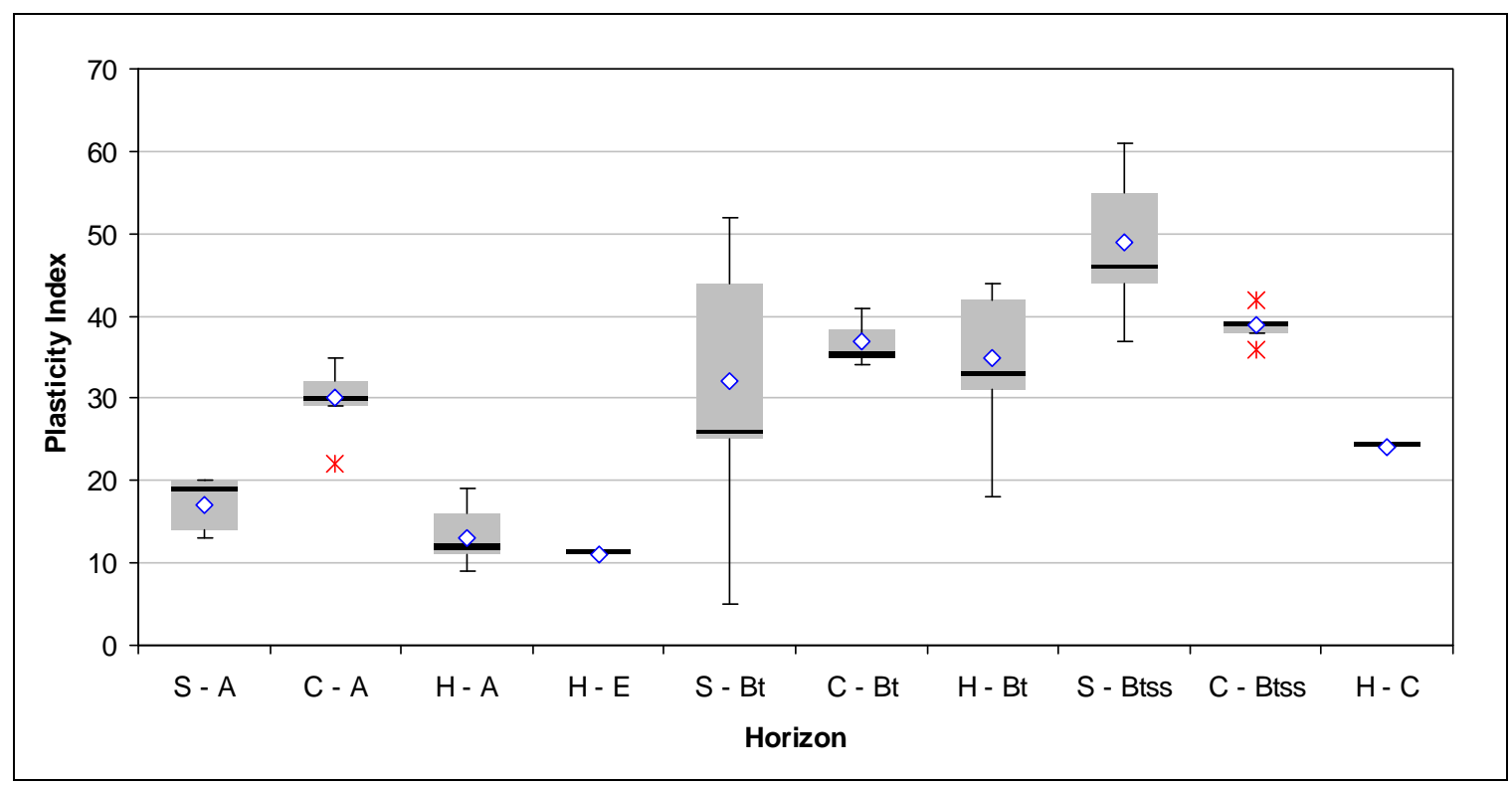

Figure 14. Distribution of plasticity index values for clayey soils.

\section{Chemical Properties}

pH

The single most diagnostic chemical measurement made on soil is $\mathrm{pH}$ (McBride, 1994). The $\mathrm{pH}$ value is defined as the negative logarithm to the base of 10 of hydrogen ion activity. The use of a dilute salt solution, such as calcium chloride $\left(\mathrm{CaCl}_{2}\right)$, is a popular method used for masking seasonal variation in soil pH (Soil Survey Staff, 2004). If the $\mathrm{pH}$ is measured in a salt such as $0.01 \mathrm{M} \mathrm{CaCl}_{2}$, the error in $\mathrm{pH}$ reading caused by charged, suspended particles is suppressed (McBride, 1994). The $\mathrm{pH}$ readings are usually less (one unit to half a unit) with dilute salt solutions than with distilled water (Soil Survey Staff, 2004).

Soil reaction was determined by two methods, $1: 1$ water $\mathrm{pH}$ and 1:2 calcium chloride $\left(\mathrm{CaCl}_{2}\right) \mathrm{pH}$. The Carbo soil shows an increase in $\mathrm{pH}$ with depth (Figures 15 \& 16). Hagerstown soil shows an initial increase in $\mathrm{pH}$ then a decrease in $\mathrm{pH}$ with depth. Swanpond soil shows a slight increase in $1: 1$ water $\mathrm{pH}$ initially then a decrease in $\mathrm{pH}$ with depth (Figure 15). Calcium chloride $\mathrm{pH}$ decreased in depth for the Swanpond soil (Figure 16). Carbo soil had the highest average $\mathrm{pH}$ values. Both Carbo and Swanpond soils had higher average $\mathrm{pH}$ values than the Hagerstown soil. Calcium chloride values 


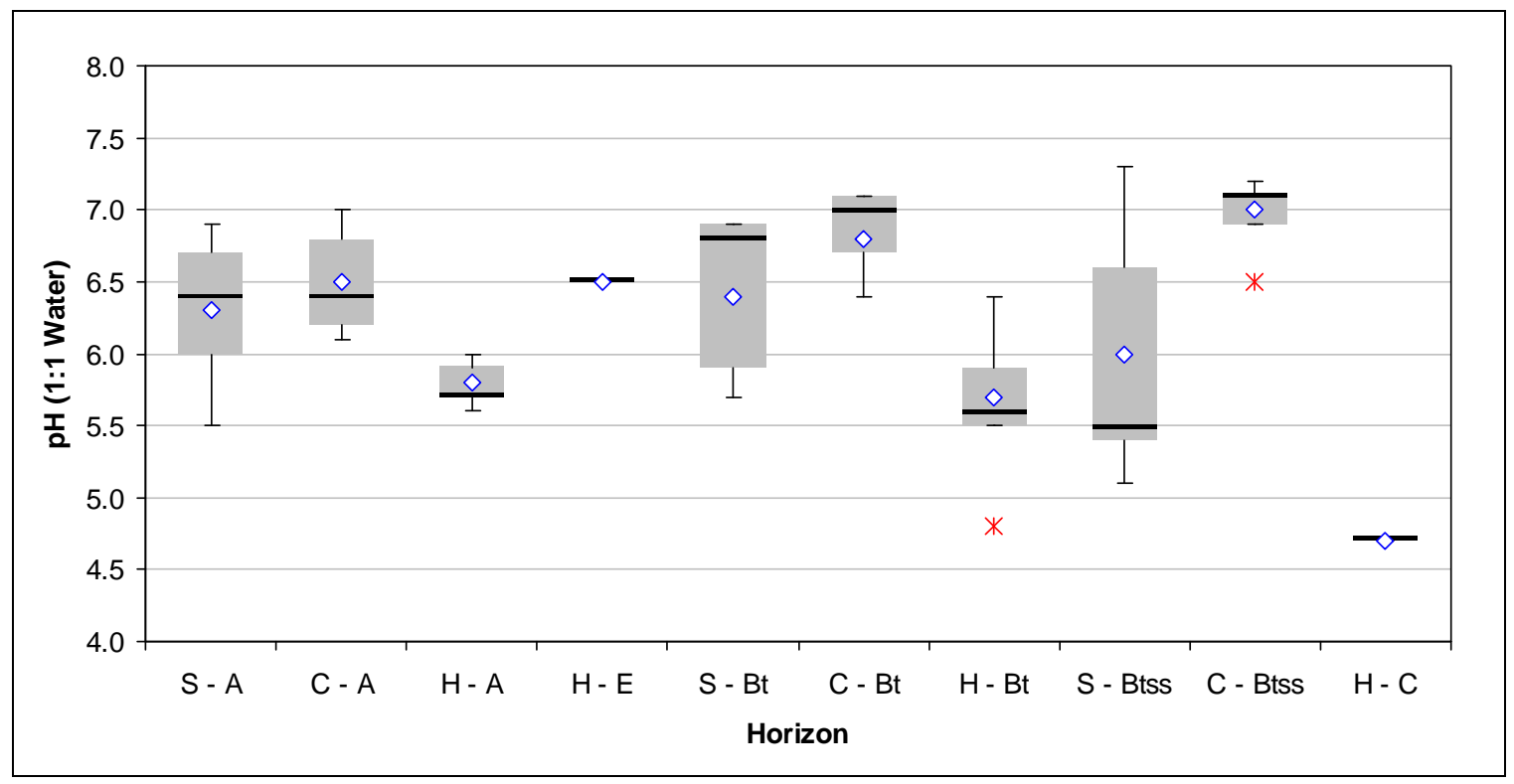

Figure 15. Distribution of $\mathrm{pH}$ (1:1 water) for clayey soils.

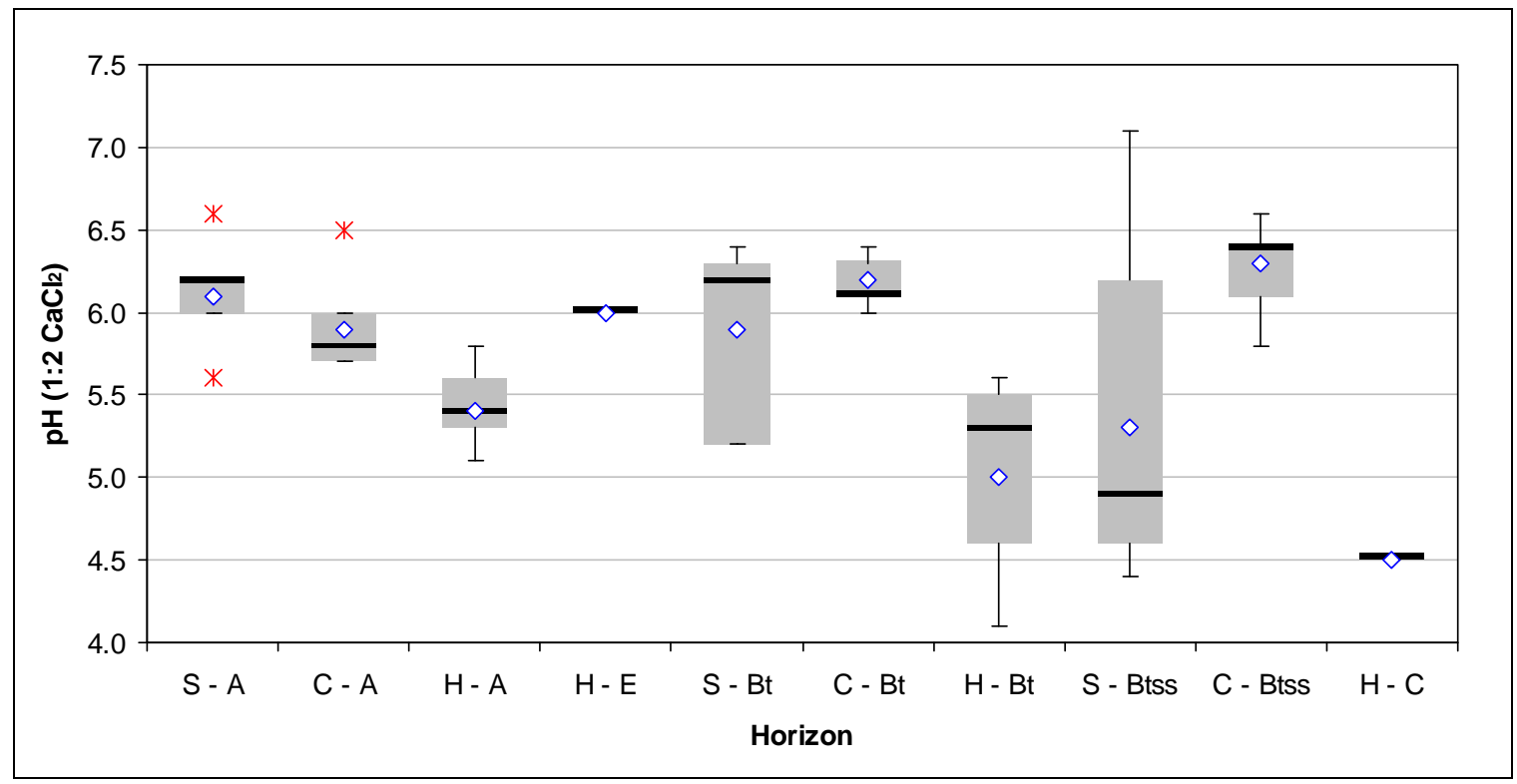

Figure 16. Distribution of $\mathrm{pH}$ (1:2 calcium chloride) for clayey soils.

were lower than water $\mathrm{pH}$ for all soils as expected. The highest average 1:1 water $\mathrm{pH}$ (7.0) and 1:2 calcium chloride $\mathrm{pH}$ (6.3) occurred in the Carbo Btss horizon. The lowest average 1:1 water $\mathrm{pH}(4.7)$ and 1:2 calcium chloride $\mathrm{pH}$ (4.5) occurred in the Hagerstown $\mathrm{C}$ horizon. The elevated values of the Hagerstown E may be due to agricultural liming. 


\section{Extractable Acidity}

Extractable acidity was determined by the barium chloride-triethanolamine, $\mathrm{pH}$ 8.2 extraction method. Extractable acidity is the acidity released from the soil by barium chloride-triethanolamine solution buffered at $\mathrm{pH} 8.2$ and includes all the acidity generated by replacement of the hydrogen and aluminum from permanent and $\mathrm{pH}-$ dependent exchange sites (Soil Survey Staff, 2004).

Average extractable acidity decreased from the A and Bt horizons to the Btss horizon in the Carbo soil and increased with depth in the Swanpond soil while the Hagerstown soil decreased initially then increased with depth (Figure 17). The lowest average extractable acidity occurred in the Hagerstown $\mathrm{E}$ horizon $\left(3.3 \mathrm{cmol}_{\mathcal{C}} / \mathrm{kg}\right)$. The highest average extractable acidity occurred in the Hagerstown $\mathrm{C}$ horizon (12.8 $\mathrm{cmol}_{\mathrm{c}} / \mathrm{kg}$ ). It is unclear why the $\mathrm{C}$ horizon in Hagerstown is so much higher than other horizons. Several pedons including Swanpond \#1, Swanpond \#3, Swanpond \#4, Hagerstown \#1, and Hagerstown \#3 have elevated extractable acidity values in horizons near the bottom of the profiles (See laboratory data in Appendices A, B and C). These elevated values could possibly be a geology related phenomenon, where the chemistry make up of the limestone parent material has changed, or an error in the laboratory procedure.

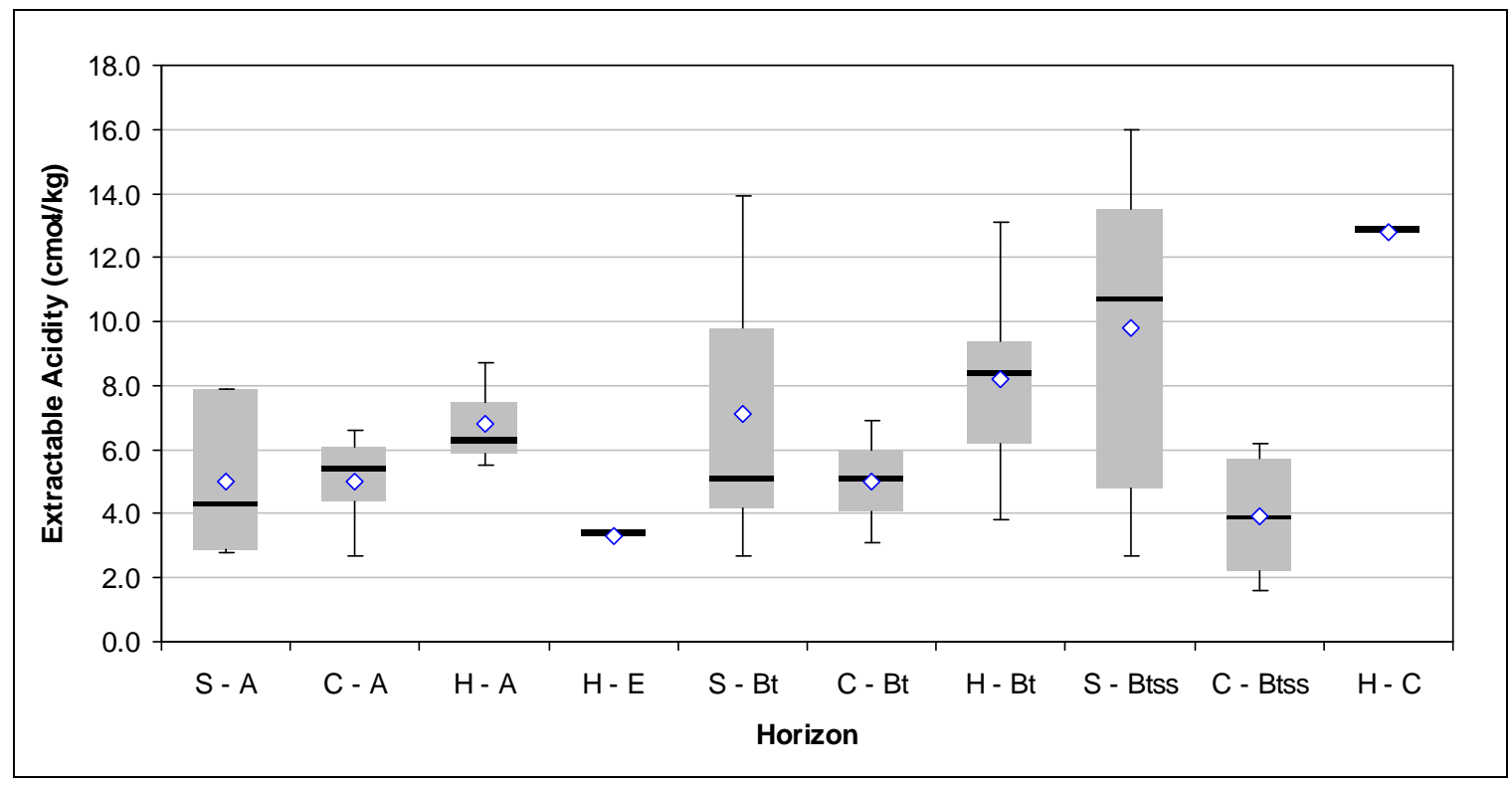

Figure 17. Distribution of extractable acidity for clayey soils. 


\section{Extractable Bases}

The average sum of extractable bases is given in Figure 18. The highest average sum of extractable bases occurred in the Carbo Btss horizon $(27.3 \mathrm{meq} / 100 \mathrm{~g})$. The lowest average sum of extractable bases occurred in the Hagerstown C horizon (3.6 meq/100g). Of the four extractable bases (calcium, magnesium, sodium, and potassium), calcium levels were higher than the other bases in each of the pedons (see Appendices). Calcium is typically the most abundant exchangeable cation in soils. Calcium values were highest in the Carbo pedons and lowest in the Hagerstown pedons. Magnesium values were higher in the Swanpond pedons than the Carbo or Hagerstown pedons. Sodium and potassium values were similar for all pedons.

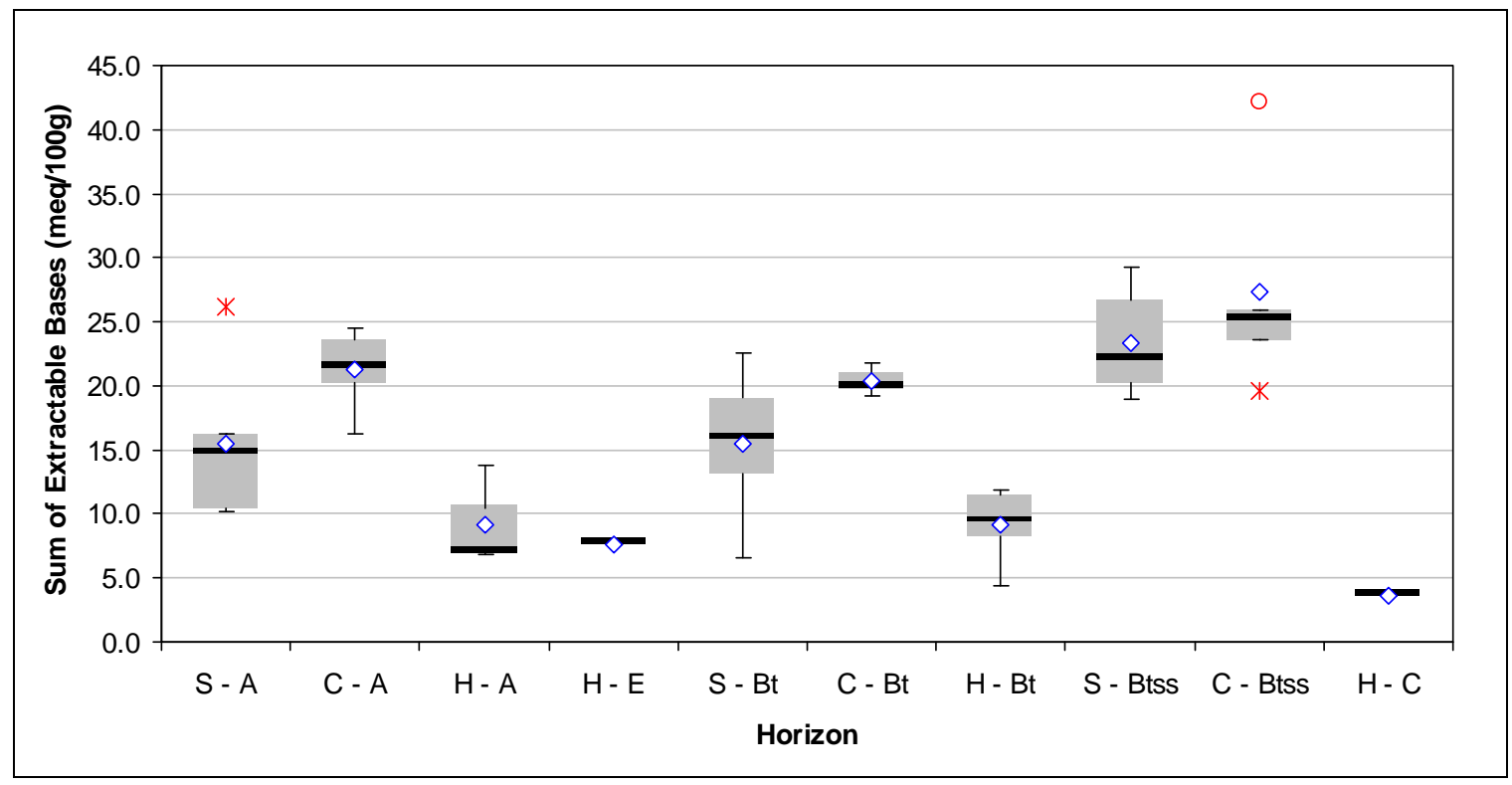

Figure 18. Distribution of sum of extractable bases for clayey soils.

\section{CEC}

Cation exchange capacity is a measure of the total quantity of negative charges per unit weight of the material. Cation exchange capacity was determined by two methods, sum of extractable cations (CEC-8.2) and ammonium acetate (CEC-7). Highest average cation exchange capacity was recorded in the Btss horizons of the Carbo and Swanpond soils and in the Bt horizon of the Hagerstown soil (Figures $19 \& 20$ ). The highest average ammonium acetate CEC occurred in the Carbo Btss horizon (28.4 
$\mathrm{cmol}_{\mathcal{C}} / \mathrm{kg}$ ). The highest sum of extractable cations CEC occurred in the Swanpond Btss horizon $\left(33.0 \mathrm{cmol}_{\mathcal{C}} \mathrm{kg}\right)$. Average cation exchange capacity was higher in all soils using the sum of extractable cations (CEC-8.2) method, however trends were similar between the two methods.

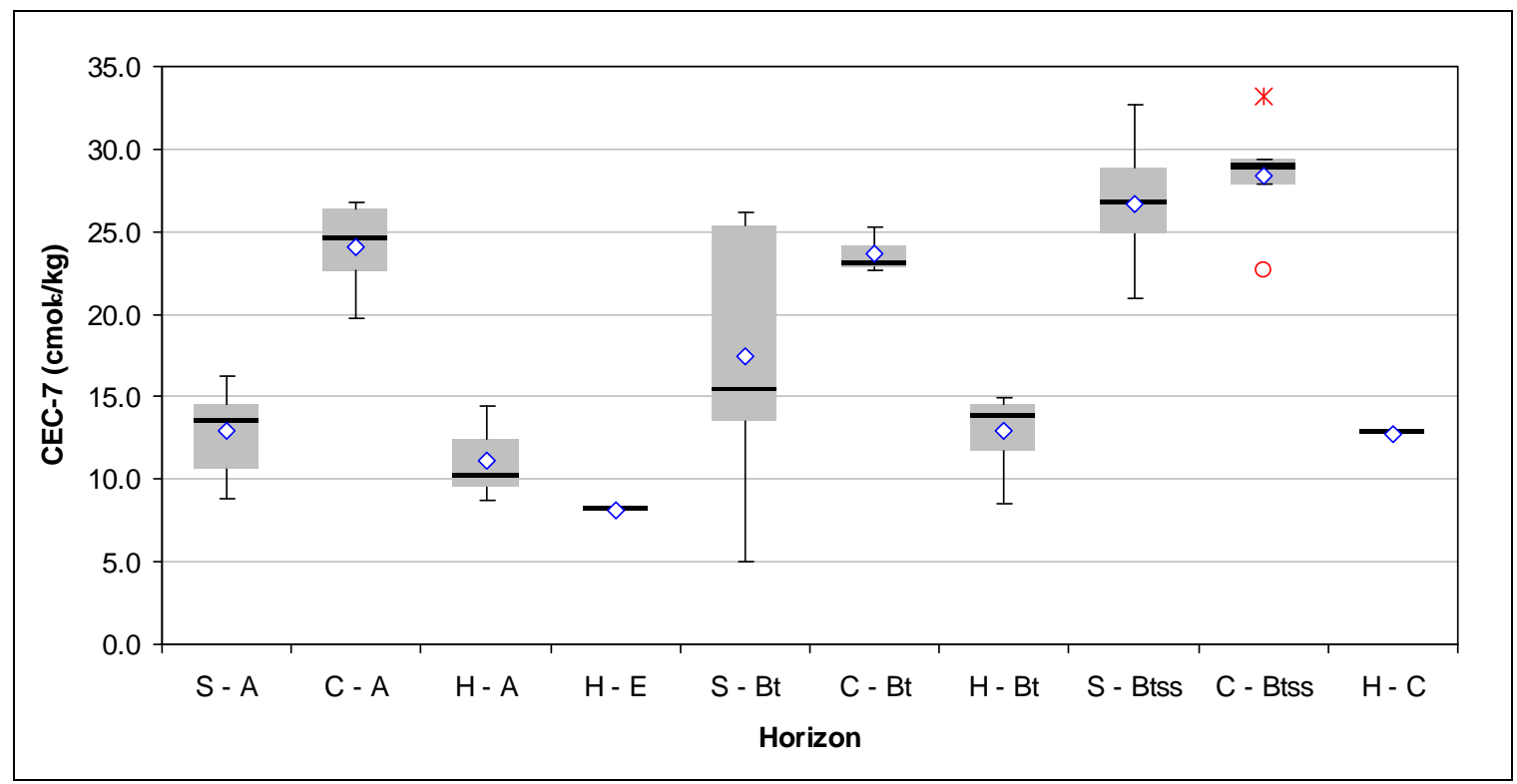

Figure 19. Distribution of CEC determined by the ammonium acetate method for clayey soils.

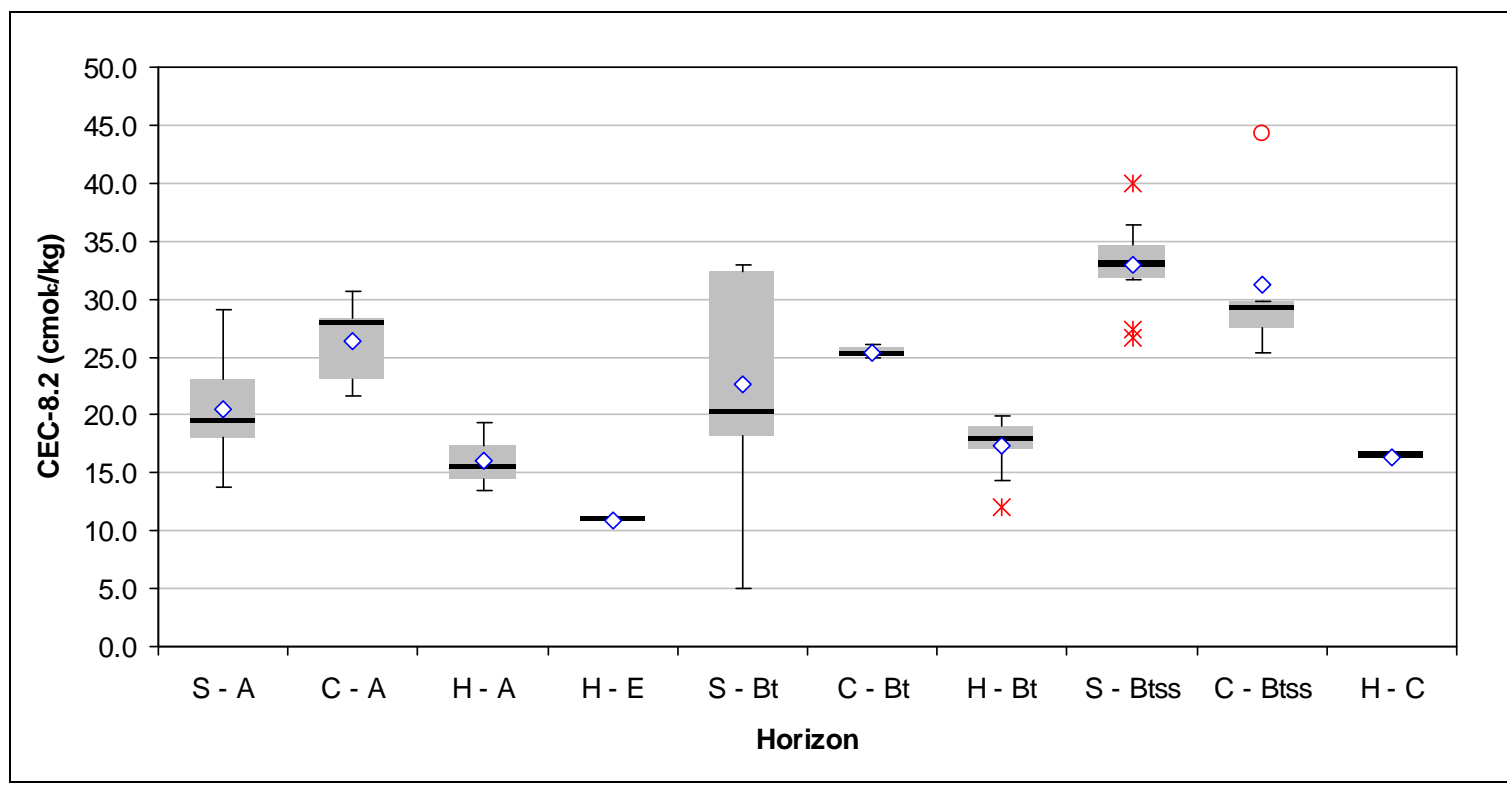

Figure 20. Distribution of CEC determined by summation of cations for clayey soils. 


\section{Mineralogy}

As stated earlier, smectite is the clay mineral most commonly associated with shrink-swell potential. However, pure montmorillonite was present only in the Swanpond \#2 and Hagerstown \#2 pedons (Table 3). Montmorillonite-mica occurred in the three Carbo pedons. Although montmorillonite and montmorillonite-mica was present in these five pedons, it was not the dominant clay mineral. Surprisingly the Hagerstown \#2 pedon showed no evidence of shrink-swell even though montmorillonite was present. Kaolinite, present in all pedons, was the dominant mineral in 6 of the 10 pedons sampled which included the three Hagerstown pedons and Swanpond \#1, \#3, and \#4 pedons. The remaining pedons (Carbo \#1, \#2, \#3, and Swanpond \#2) had mica as the dominant mineral. Vermiculite was present in all pedons. Other clay-sized minerals including goethite, quartz, hematite, chlorite, chlorite-mica and vermiculite-mica were present in one or more pedons. Similar clay-sized minerals were found by Thomas (1998) in the Carbo soils in Virginia; however, smectite minerals were the dominant mineral in those soils. In central Pennsylvania, Cronce (1988) found similar clay-sized minerals in Hagerstown soils; however, mica was the dominant mineral in those soils.

Table 3. Minerals present in the clay-sized fraction of each pedon.

\begin{tabular}{|c|c|c|c|c|c|c|c|c|c|c|}
\hline Mineral & 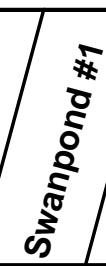 & 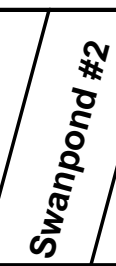 & 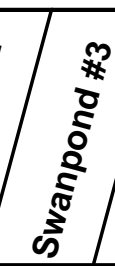 & 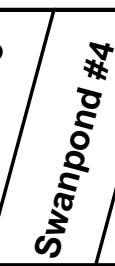 & ${ }_{0}^{*}$ & : & 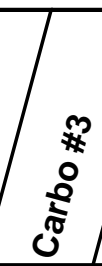 & 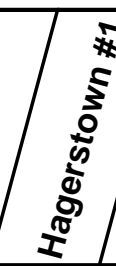 & 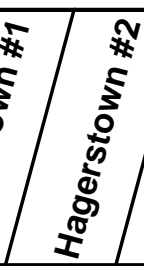 & 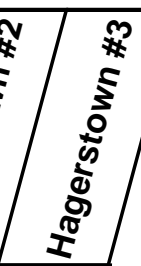 \\
\hline Gibbsite & & & & & & & & $\bar{X}$ & & \\
\hline Geothite & & $\mathrm{X}$ & $\bar{x}$ & $\bar{x}$ & $\mathrm{X}$ & $\mathrm{X}$ & $\mathrm{X}$ & & $\bar{x}$ & $\bar{X}$ \\
\hline Hematite & & & & & & & & $\mathrm{X}$ & & $\mathrm{X}$ \\
\hline Kaolinite & $\mathrm{X}$ & $\mathrm{X}$ & $\bar{X}$ & $\bar{X}$ & $\mathrm{X}$ & $\mathrm{X}$ & $\mathrm{X}$ & $\bar{X}$ & $\bar{X}$ & $\bar{X}$ \\
\hline Mica & $\bar{X}$ & $\mathrm{X}$ & $\bar{X}$ & $\bar{X}$ & $\mathrm{X}$ & $\mathrm{X}$ & $\mathrm{X}$ & $\mathrm{X}$ & & \\
\hline Vermiculite & $\mathrm{X}$ & $\mathrm{X}$ & $\mathrm{X}$ & $\mathrm{X}$ & $x$ & $x$ & $x$ & $\mathrm{X}$ & $\mathrm{X}$ & $\mathrm{X}$ \\
\hline Montmorillonite & & $\mathrm{X}$ & & & & & & & $\mathrm{X}$ & \\
\hline Chlorite & & & & & & & & $\mathrm{X}$ & & \\
\hline Vermiculite-Mica & & & & & & & & & $\bar{X}$ & \\
\hline Montmorillonite-Mica & & & & & $\bar{X}$ & $\bar{X}$ & $\mathrm{X}$ & & & \\
\hline Chlorite-Mica & & & & & & & & & & $\bar{X}$ \\
\hline Quartz & $\mathrm{X}$ & & & & $\mathrm{X}$ & $\mathrm{X}$ & $\mathrm{X}$ & & & \\
\hline
\end{tabular}




\section{Statistical Analysis}

Weighted averages of percent clay, COLE, and plasticity index in the argillic horizon were calculated for each soil series. Analysis of variance (ANOVA) was used to analyze soil series versus weighted averages of those selected soil properties in the argillic horizon. Similar soils were grouped together based on Duncan's multiple range test. Results of the Duncan's multiple range test are displayed in Table 4. Clay and plasticity index values are significantly different in Swanpond and Hagerstown soils. Coefficient of linear extensibility values of Hagerstown soils are significantly different than both Carbo and Swanpond soils.

Table 4. Duncan's Multiple Range Tests used to group similar soils based on weighted averages (shown in parentheses) of selected soil properties.

\begin{tabular}{cccc} 
& Clay & COLE & PI \\
Swanpond & A (69.8) & A (0.05) & A (45) \\
Carbo & A, B (62.3) & A (0.05) & A, B (38) \\
Hagerstown & B (54.6) & B (0.02) & B (37) \\
\hline * Soils with the same letter are not significantly different.
\end{tabular}

Linear regression analyses were used to correlate relationships of selected physical and chemical soil properties. Linear regression relationships between COLE and selected soil physical and chemical properties (Table 5) indicate that COLE is highly correlated with clay, plasticity index, summation of cations derived cation exchange capacity, and ammonium acetate cation exchange capacity. The $\mathrm{r}^{2}$ values show that COLE vs CEC-7, CEC-8.2, clay, and PI account for 81, 70, 69, and 58 percent of the total variance of COLE, respectively. Yerima et al. (1989) used simple linear regression models and multiple linear regression models to predict COLE. They concluded that multiple linear regression models did not improve COLE prediction compared to simple linear regression models.

Based upon laboratory data and field observations, Swanpond and Carbo soils show evidence of high shrink-swell and Hagerstown soil shows no evidence of shrinkswell. It can be concluded from the statistical analyses that COLE is a potentially good predictor of shrink-swell in the limestone soils of the Great Valley of West Virginia since 
COLE values of the Hagerstown soil (which shows no evidence of shrink-swell) are significantly different from both Swanpond and Carbo soils (which both show evidence of shrink-swell). Even though the Hagerstown soil is significantly different than the Swanpond soil for clay and PI values, the Hagerstown soil is not significantly different than the Carbo soil; therefore clay and PI are not potentially good predictors of shrinkswell for these soils.

Table 5. Regression relationships between clay, coefficient of linear extensibility (COLE), and plasticity index (PI) and selected soil properties for clayey soils.

\begin{tabular}{cccccc}
\hline $\begin{array}{c}\text { Dependent } \\
\text { variable }\end{array}$ & Intercept & Slope & Variable† & $\mathbf{n}$ & $\mathbf{r}^{2}$ \\
\hline \multirow{2}{*}{ Clay } & 26.515 & 698.038 & COLE & 55 & $0.689^{*}$ \\
& 6.770 & 1.338 & PI & 60 & $0.898^{*}$ \\
& 10.574 & 1.720 & CEC-8.2 & 60 & $0.602^{*}$ \\
& 14.059 & 1.978 & CEC-7 & 60 & $0.646^{*}$ \\
COLE & -0.008 & 0.001 & PI & 55 & $0.579^{*}$ \\
& -0.018 & 0.002 & CEC-8.2 & 55 & $0.697^{*}$ \\
& -0.014 & 0.003 & CEC-7 & 55 & $0.814^{*}$ \\
& & & & & \\
PI & 6.086 & 1.147 & CEC-8.2 & 60 & $0.534^{*}$ \\
& 8.601 & 1.309 & CEC-7 & 60 & $0.564^{*}$ \\
\hline
\end{tabular}

* Significant at the 0.01 level

† CEC-8.2 = cation exchange capacity calculated by summation of bases and extractable acidity, CEC-7 = cation exchange capacity determined by ammonium acetate.

\section{Soil Classification}

All the soils in this study were classified to the family level using Soil Taxonomy (Soil Survey Staff, 1999). These soils were classified using the data and field descriptions located in Appendices A, B and C. Classification for each pedon is given in Table 6. All ten pedons were defined as having an ochric epipedon and an argillic diagnostic subsurface horizon.

The current taxonomic classification of the Carbo series is very-fine, mixed, active, mesic Typic Hapludalfs (Soil Survey Staff, 2008). None of the three Carbo pedons sampled fit the current classification. The Carbo \#1 and \#2 pedons classified as 
very-fine, mixed, active, mesic Leptic Hapluderts. The Carbo \#3 pedon classified as a fine, mixed, active mesic Vertic Hapludalf. The Carbo \#3 pedon did not classify as a Vertisol because it lacked the required layer of $25 \mathrm{~cm}$ or more thick containing slickensides or wedge-shaped peds that have their long axes tilted 10 to 60 degrees from the horizontal.

Table 6. Soil Taxonomy classification for each pedon.

\begin{tabular}{cccccc}
\hline $\begin{array}{c}\text { Soil Sampled } \\
\text { As }\end{array}$ & & \multicolumn{4}{c}{ Family } \\
\hline Carbo \#1 & Very-fine & mixed & active & mesic & Leptic Hapluderts \\
Carbo \#2 & Very-fine & mixed & active & mesic & Leptic Hapluderts \\
Carbo \#3 & Fine & mixed & active & mesic & Vertic Hapludalfs \\
Swanpond \#1 & Fine & mixed & semiactive & mesic & Vertic Paleudalfs \\
Swanpond \#2 & Very-fine & mixed & semiactive & mesic & Vertic Paleudalfs \\
Swanpond \#3 & Very-fine & mixed & semiactive & mesic & Oxyaquic Hapluderts \\
Swanpond \#4 & Very-fine & mixed & semiactive & mesic & Chromic Hapluderts \\
Hagerstown \#1 & Fine & mixed & semiactive & mesic & Typic Hapludults \\
Hagerstown \#2 & Fine & mixed & semiactive & mesic & Typic Paleudalfs \\
Hagerstown \#3 & Fine & mixed & subactive & mesic & Typic Paleudults \\
\hline
\end{tabular}

The current taxonomic classification of the Swanpond series is very-fine, mixed, active, mesic Vertic Paleudalfs (Soil Survey Staff, 2008). Of the four Swanpond pedons sampled, only the Swanpond \#2 pedon fits the current classification. The Swanpond \#1 pedon classified as a fine, mixed, semiactive, mesic Vertic Paleudalf, which does not meet the current classification because it did not have the required amount of clay (60 percent weighted average) in the control section to have a particle-size class of very-fine at the family level. The Swanpond \#3 pedon classified as a very-fine, mixed, semiactive, mesic Oxyaquic Hapludert. The Swanpond \#4 pedon classified as a very-fine, mixed, semiactive, mesic Chromic Hapludert. The Swanpond \#1 and \#2 pedons did not classify as Vertisols because they lacked the required weighted average of 30 percent or more 
clay in the fine-earth fraction either between the mineral soil surface and a depth of 18 $\mathrm{cm}$ or in an Ap horizon, whichever is thicker.

The current taxonomic classification of the Hagerstown series is fine, mixed, semiactive, mesic Typic Hapludalfs (Soil Survey Staff, 2008). None of the three Hagerstown pedons sampled fit the current classification. The Hagerstown \#1 pedon, which classified as a fine, mixed, semiactive, mesic Typic Hapludult, did not have the required base saturation (35\% or greater by sum of cations) to classify in the Alfisol order. The Hagerstown \#2 pedon (fine, mixed, semiactive, mesic Typic Paleudalf) met the criteria to classify as a Paleudalf, which keys out before Hapludalfs in taxonomy, at the great group level of classification. The Hagerstown \#3 pedon classified as a fine, mixed, subactive, mesic Typic Paleudult. Like the Hagerstown \#1 pedon, the Hagerstown \#3 pedon lacked the required base saturation to classify as an Alfisol at the order level. Similar to the Hagerstown \#2 pedon, the Hagerstown \#3 pedon met the criteria to classify as a Paleudult, which keys out before Hapludults, at the great group level of classification. In addition to the differences in the order and great group levels of classification, the Hagerstown \#3 pedon did not met the required ratio of cation-exchange capacity (by $\mathrm{NH}_{4} \mathrm{OAc}$ at $\mathrm{pH} 7$ ) to clay (percent by weight) for the semiactive cationexchange activity class ( 0.24 to 0.40 ) at the family level of classification.

Other soils in the surrounding area also have been noted as having high shrinkswell potential (Table 7). According to the Soil Survey Staff (2008), Pagebrook (fine, smectitic, mesic Oxyaquic Hapluderts), Endcav (very-fine, mixed, semiactive, mesic Chromic Vertic Hapludalfs) and Oaklet (very-fine, mixed, semiactive, mesic Vertic Paleudalfs) are soils whose classifications indicate high shrink-swell. Classification of these three soils was revised in November 2005 to account for the high shrink-swell potential (Soil Survey Staff, 2008). They were previously classified as Pagebrook (fine, smectitic, mesic, Vertic Eutrudepts), Endcav (very-fine, mixed, mesic Typic Hapludalfs) and Oaklet (very-fine, mixed, mesic, Typic Paleudalfs). Poplimento (fine, mixed, subactive, mesic Ultic Hapludalfs) and Opequon (clayey, mixed, active, mesic Lithic Hapludalfs) are soils that do not indicate high shrink-swell based upon classification, but have slickensides and pressure faces described in the Official Series Descriptions (Soil Survey Staff, 2008). Area Soil Scientists have also mentioned Swimley (very-fine, 
Table 7. Acreages of soils with shrink-swell potential in the Great Valley of West Virginia and nearby areas.

\begin{tabular}{|c|c|c|c|c|c|c|c|c|c|c|c|c|c|c|c|c|}
\hline \multirow{3}{*}{\begin{tabular}{|c} 
Location \\
County
\end{tabular}} & \multicolumn{16}{|c|}{ Soils } \\
\hline & \multicolumn{2}{|c|}{ Carbo } & \multicolumn{2}{|c|}{ Swanpond } & \multicolumn{2}{|c|}{ Pagebrook } & \multicolumn{2}{|c|}{ Endcav } & \multicolumn{2}{|c|}{ Oaklet } & \multicolumn{2}{|c|}{ Poplimento } & \multicolumn{2}{|c|}{ Opequon } & \multicolumn{2}{|c|}{ Swimley } \\
\hline & ac. & $\%$ & ac. & $\%$ & ac. & $\%$ & ac. & $\%$ & ac. & $\%$ & ac. & $\%$ & ac. & $\%$ & ac. & $\%$ \\
\hline $\begin{array}{l}\text { Berkeley } \\
\text { (WV) }\end{array}$ & 2638 & 1.3 & 2640 & 1.3 & -- & -- & 467 & 0.2 & -- & -- & -- & -- & 4263 & 2.1 & -- & -- \\
\hline $\begin{array}{c}\text { Jefferson } \\
\text { (WV) }\end{array}$ & 2782 & 2.2 & -- & -- & -- & -- & -- & -- & 9639 & 7.6 & 21147 & 17.0 & 3812 & 3.1 & -- & -- \\
\hline $\begin{array}{l}\text { Frederick } \\
\text { (VA) }\end{array}$ & 4380 & 2.0 & -- & -- & 2197 & 1.0 & -- & -- & 11306 & 5.1 & 14396 & 6.5 & 543 & 0.2 & 1594 & 0.7 \\
\hline $\begin{array}{c}\text { Clarke } \\
(\mathrm{VA})\end{array}$ & 2522 & 3.3 & -- & -- & 3643 & 4.8 & 693 & 0.9 & 1798 & 2.4 & 15877 & 20.8 & 4011 & 5.3 & 4020 & 5.3 \\
\hline Warren (VA) & 809 & 0.7 & -- & -- & -- & -- & 1831 & 1.6 & -- & -- & -- & -- & -- & -- & -- & -- \\
\hline $\begin{array}{l}\text { Shenandoah } \\
\text { (VA) }\end{array}$ & 5407 & 2.1 & -- & -- & -- & -- & 13266 & 5.2 & -- & -- & 18721 & 7.3 & 1808 & 0.7 & -- & -- \\
\hline $\begin{array}{l}\text { Page } \\
\text { (VA) }\end{array}$ & 2856 & 1.7 & -- & -- & -- & -- & -- & -- & 1892 & 1.1 & -- & -- & -- & -- & -- & -- \\
\hline $\begin{array}{l}\text { Rockingham } \\
\text { (VA) }\end{array}$ & 4746 & 1.2 & -- & -- & -- & -- & 10116 & 2.5 & -- & -- & -- & -- & -- & -- & 1390 & 0.3 \\
\hline $\begin{array}{l}\text { Washington } \\
\text { (MD) }\end{array}$ & -- & -- & 11375 & 4.1 & -- & -- & -- & -- & -- & -- & -- & -- & 11703 & 4.3 & -- & -- \\
\hline $\begin{array}{l}\text { Fulton } \\
\text { (PA) }\end{array}$ & 697 & 0.3 & -- & -- & -- & -- & -- & -- & -- & -- & -- & -- & -- & -- & -- & -- \\
\hline $\begin{array}{l}\text { Franklin } \\
\text { (PA) }\end{array}$ & 12855 & 3.1 & 1107 & 0.3 & -- & -- & -- & -- & -- & -- & -- & -- & -- & -- & -- & -- \\
\hline
\end{tabular}


mixed, semiactive, mesic Typic Paleudalfs) as a soil that is thought to have high shrinkswell although the Official Series Description and classification indicate otherwise. As older county soil surveys in the area are updated, it is possible that the acreages of soils recognized with high shrink-swell potential will increase due to the increased amount of data available and observations that have occurred since the previous county soil survey report was published. Of the counties listed in Table 7, only Berkeley, Jefferson, Washington, Fulton and Franklin counties have been recently updated.

With the supporting laboratory data and field observations from this research and the recent classification revisions for soils with high shrink-swell potential in the surrounding area, it is proposed that the classification of the Carbo series also be updated to recognize the shrink-swell potential of that soil. It is recommended that the subgroup classification of the Carbo series be changed from Typic to Vertic in order to recognize the high shrink-swell potential. 


\section{Summary and Conclusions}

This research study, previous field trips, and work done by local soil scientists have shown that soils with the potential for shrinking and swelling are present in the Great Valley of West Virginia and surrounding states. Field observations and laboratory data indicate that the Carbo and Swanpond pedons investigated in this research study have a high potential for shrinking and swelling. The Hagerstown pedons in this research study do not indicate any field or laboratory evidence of high shrink-swell potential.

Field observations of the Carbo and Swanpond pedons indicate a very high shrink-swell potential based upon the amount and immensity of slickensides and cracks that are present in these pedons. Although these soils have been mapped on different geologies, geology may still play a role in the shrink-swell of these soils as these geological formations overlap in lithologies. No geologic control could be determined at the formation level in this research study.

The laboratory data for Carbo and Swanpond pedons, particularly the COLE values, also indicate a high shrink-swell potential. Although COLE values are similar to those of Thomas (1998), the COLE values may not reflect the highest shrink-swell of these soils when compared to the field observations. COLE values may have been affected by the saran coating on the soil clods, which prevented maximum swelling of the clod (Tunny, 1970). Since shrink-swell was not measured using another method, it is uncertain whether the COLE values presented in this research are an accurate measurement of maximum shrink-swell in the Carbo and Swanpond pedons or if these COLE values underestimate the shrink-swell in these soils. Even though the Carbo and Swanpond soils exhibit high shrink-swell based on field observations and COLE values, they lack appreciable amounts of the smectitic clay minerals that are common in soils with high shrink-swell. This may be explained by the high clay percentages and large amounts of kaolinite present which have similar physical behavior to smectitites (Yerima et al., 1985, 1987).

Physical and chemical properties of the Carbo and Hagerstown pedons in this study are similar to those of Carbo pedons investigated by Thomas (1998) in Virginia and the Hagerstown pedons investigated by Cronce (1988) in Pennsylvania. 
This research study formally documents field and laboratory evidence of high shrink-swell potential in two of these soils, Carbo and Swanpond. All seven pedons investigated of these two soils, show evidence of shrink-swell potential identified either at the order or subgroup classification levels of Soil Taxonomy (Soil Survey Staff, 1999).

Since the inception of this research, the Swanpond series classification has been updated to recognize the shrink-swell potential of that soil; a Typic subgroup was replaced by a Vertic subgroup classification. Based upon the field and laboratory evidence presented in this study, it is recommended that the classification of the Carbo series also be updated to recognize the shrink-swell potential of that soil.

Although two of the Carbo pedons and two of the Swanpond pedons in this study classified at the order level as Vertisols, it is unclear based upon this research how widely these may occur across the area. It is possible that the pedons classifying as Vertisols are inclusions or minor components of the soil map unit and do not represent the major component of the soil map unit. Further research would be necessary to determine their occurrence across the landscape. It is apparent, however, that these soils exhibit shrinkswell potential and the Vertic subgroup designation would recognize that shrink-swell in the classification scheme. Therefore, it is recommended that the classification of Carbo series be changed from a Typic subgroup to a Vertic subgroup. Updating the classification of the Carbo soils would not only impact the Great Valley of West Virginia but other areas where the Carbo soils are mapped including areas of Pennsylvania, Virginia and Tennessee.

Recent research, observations by local soil scientists and others should be used to update classification of other soils (Table 7) that have the potential for shrink-swell but do not have classification that recognizes the shrink-swell potential. 


\section{References}

American Society for Testing and Materials. 2000. Annual book of ASTM standards. Construction. Section 4. Soil and rock; dimension stone; geosynthesis. Vol. 04.08. ASTM, Philadelphia, PA.

Anderson, J.U. Kamal Elfadil Fadul, and G.A. O'Conner. 1973. Factors affecting the coefficient of linear extensibility in Vertisols. Soil Sci. Soc. Am. Proc. 37:296299.

Ballagh, T.M. and E.C.A. Runge. 1970. Clay-rich horizons over limestone-illuvial or residual? Soil Sci. Soc. Am. Proc. 34:534-536.

Barnhisel, R.I. and P.M. Bertsch. 1989. Chlorites and hydroxyl-interlayered vermiculite and smectite. p. 729-788. In J.B. Dixon and S.B. Weed (ed.) Minerals in soil environments. $2^{\text {nd }}$ ed. SSSA Book Ser. No. 1. SSSA, Madison, WI.

Bartelli, L.J. and D.E. McCormack. 1976. Morphology and pedologic classification of swelling soils. Transportation Research Record 568:1-8. Natl. Res. Counc. Washington, DC.

Bell, J.W. 2002. Soil Survey of Berkeley County, West Virginia. U.S. Gov. Print. Office, Washington, DC.

Borchardt, G. 1989. Smectites. p. 675-727. In J.B. Dixon and S.B. Weed (ed.) Minerals in soil environments. $2^{\text {nd }}$ ed. SSSA Book Ser. No. 1. SSSA, Madison, WI.

Brasher, B.R., D.P. Franzmeier, V. Valassis, and S.E. Davidson. 1966. Use of saran resin to coat natural soil clods for bulk-density and water-retention measurements. Soil Sci. 101:108.

Buol, S.W., F.D. Hole, R.J. McCracken, and R.J. Southard. 1997. Soil genesis and classification. $4^{\text {th }}$ ed. Iowa State Press, Ames.

Buol, S.W., R.J. Southard, R.C. Graham, and P.A. McDaniel. 2003. Soil genesis and classification. $5^{\text {th }}$ ed. Iowa State Press, Ames.

Casagrande, A. 1948. Classification and identification of soils. Trans. Am. Soc. Civil Eng. 113:901-931.

Ciolkosz, E.J., B.J. Carter, M.T. Hoover, R.C. Cronce, W.J. Waltman, and R.R. Dobos. 1990a. Genesis of soils and landscapes in the Ridge and Valley province of central Pennsylvania. Geomorphology 3:245-261.

Ciolkosz, E.J. and R.R. Dobos. 1990b. Color and mottling in Pennsylvania soils. Pennsylvania State Univ. Agron. Ser. No. 108. University Park. 
Ciolkosz, E.J., N.C. Thurman, W.J. Waltman, D.L. Cremeens, and M.D. Svoboda. 1994. Argillic horizons in Pennsylvania soils. Pennsylvania State Univ. Agron. Ser. No. 131. University Park.

Ciolkosz, E.J., R.C. Cronce, W.D. Sevon, and W.J. Waltman. 1995. Genesis of Pennsylvania's limestone soils. Pennsylvania State Univ. Agron. Ser. No. 135. University Park.

Coulombe, C.E., L.P. Wilding, and J.B. Dixon. 2000. Vertisols. p. E269-E286. In M.E. Sumner (ed.) Handbook of soil science. CRC Press, Boca Raton, FL.

Cronce, R.C. 1988. The genesis of soils overlying dolomite in the Nittany Valley of Central Pennsylvania. Ph.D. diss. Pennsylvania State Univ., State College.

Dasog, G.S., D.F. Acton, A.R. Mermut, and E. De Jong. 1988. Shrink-swell potential and cracking in clay soils of Saskatchewan. Can. J. Soil Sci. 68:251-260.

Davidson, S.E. and J.B. Page. 1956. Factors influencing swelling and shrinking in soils. Soil Sci. Soc. Am. Proc. 20:320-324.

Dean, S.L. 1966. Geology of the Great Valley of West Virginia. Ph.D. diss. West Virginia Univ., Morgantown.

Dean, S.L., B.R. Kulander, P. Lessing. 1987. Geology of the Hedgesville, Keedysville, Martinsburg, Shepherdstown, and Williamsport Quadrangles, Berkeley and Jefferson Counties, WV. West Virginia Geological and Economic Survey: MAPWV31, 1:24,000.

DeMent, J.A. and L.J. Bartelli. 1969. The role of vertic subgroups in the comprehensive soil classification system. Soil Sci. Soc. Am. Proc. 33:129-131.

Dixon, J.B. 1989. Kaolin and serpentine group minerals. p. 467-525. In J.B. Dixon and S.B. Weed (ed.) Minerals in soil environments. $2^{\text {nd }}$ ed. SSSA Book Ser. No. 1. SSSA, Madison, WI.

Douglas, L.A. 1989. Vermiculites. p. 635-674. In J.B. Dixon and S.B. Weed (ed.) Minerals in soil environments. $2^{\text {nd }}$ ed. SSSA Book Ser. No. 1. SSSA, Madison, WI.

Dress, L.R., L.P. Wilding, N.E. Smeck, and A.L. Senkayi. 1989. Silica in soils: Quartz and disordered silica polymorphs. p. 913-974. In J.B. Dixon and S.B. Weed (ed.) Minerals in soil environments. $2^{\text {nd }}$ ed. SSSA Book Ser. No. 1. SSSA, Madison, WI.

Emmons, W.H., I.S. Allison, C.R. Stauffer, and G.A. Thiel. 1960. Geology: Principles and processes. McGraw-Hill Book Company, New York. 
Fanning, D.S. and M.C.B. Fanning. 1989. Soil morphology, genesis, and classification. John Wiley \& Sons, New York.

Fanning, D.S., V.Z. Kermidas, and M.A. El-Desoky. 1989. Micas. p. 551-634. In J.B. Dixon and S.B. Weed (ed.) Minerals in soil environments. $2^{\text {nd }}$ ed. SSSA Book Ser. No. 1. SSSA, Madison, WI.

Franzmeier D.P. and S.J. Ross, Jr. 1968. Soil swelling: Laboratory measurement and relation to other soil properties. Soil Sci. Soc. Am. Proc. 32:573-577.

Gill, W.R. and C.A. Reaves. 1957. Relationships of Atterberg limits and cation-exchange capacity to some physical properties of soil. Soil Sci. Soc. Am. Proc. 21:491-494.

Gorman, J.L., J.K. Pasto, and C.D. Crocker. 1960. Soil survey of Berkeley County, West Virginia. U.S. Gov. Print. Office, Washington, DC.

Goudie, A.S. 1995. The changing earth: Rates of geomorphological processes. Blackwell Publ., Cambridge, MA.

Grimsley, G.P. and I.C. White. 1916. West Virginia Geological Survey County ReportsJefferson, Berkeley and Morgan Counties. Wheeling News Litho. Co. Wheeling, WV.

Grossman, R.B., B.R. Brasher, D.P. Franzmeier, and J.L. Walker. 1968. Linear extensibility as calculated from natural-clod bulk density measurement. Soil Sci. Soc. Am. Proc. 32:570-573.

Hillel, D. 1998. Environmental soil physics. Academic Press, San Diego, CA.

Holmgren, G. 1968. Nomographic calculation of linear extensibility in soils containing coarse fragments. Soil Sci. Soc. Amer. Proc. 32:568-570.

Hsu, Pa Ho. 1989. Aluminum hydroxides and oxyhydroxides. p. 331-378. In J.B. Dixon and S.B. Weed (ed.) Minerals in soil environments. $2^{\text {nd }}$ ed. SSSA Book Ser. No. 1. SSSA, Madison, WI.

Indorante, S.J., L.R. Follmer, R.D. Hammer, and P.G. Koenig. 1990. Particle-size analysis by a modified pipette procedure. Soil Sci. Soc. Am. J. 54:560-563.

Jackson, J.A. 1997. Glossary of geology. Am. Geol. Inst., Alexandria, VA.

Karathanasis, A.D. and B.F. Hajek. 1985. Shrink-swell potential of montmorillonitic soils in udic moisture regimes. Soil Sci. Soc. Am. J. 49:159-166.

Lessing, P. 1979. Geology. p. 8. In Water in the Great Valley: People-problemsdecisions. Proc. of the 1979 Fall Public Meeting. Published by Interstate Commission on the Potomac River Basin. Rockville, MD. 
Low, P.F. and J.F. Margheim. 1979. The swelling of clay: I. Basic concepts and empirical equations. Soil Sci. Soc. Am. J. 43:473-481.

Low, P.F. 1980. The swelling of clay: II. Montmorillonites. Soil Sci. Soc. Am. J. 44:667676.

Low, P.F. 1981. The swelling of clay: III. Dissociation of exchangeable cations. Soil Sci. Soc. Am. J. 45:1074-1078.

McBride, M.B. 1989. Surface chemistry of soil minerals. p. 35-88. In J.B. Dixon and S.B. Weed (ed.) Minerals in soil environments. $2^{\text {nd }}$ ed. SSSA Book Ser. No. 1. SSSA, Madison, WI.

McBride, M.B. 1994. Environmental chemistry of soils. Oxford Univ. Press, New York.

McCormack, D.E. and L.P. Wilding. 1975. Soil properties influencing swelling in Canfield and Geeburg soils. Soil Sci. Soc. Am. Proc. 39:496-502.

McCue, J.B., J.B. Lucke, and H.P. Woodward. 1939. Limestones of West Virginia. West Virginia Geological Survey. Vol. XII. Scholl Print. Co. Parkersburg, WV.

National Agricultural Statistics Service. 2004. West Virginia state and county data Vol. 1. Geographic Area Series Part 48. 2002 Census of Agriculture. AC-02-A-48.

Norrish, K. 1954. The swelling of montmorillonite. Discuss. Faraday Soc. 18:120-134.

Odell, R.T., T.H. Thornburn, and L.J. McKenzie. 1960. Relationships of atterberg limits to some other properties of Illinois soils. Soil Sci. Soc. Am. Proc. 24:297-300.

Renton, J.J. 1994. Physical geology. West Publishing Company, St. Paul, MN.

Ross, G.J. 1978. Relationships of specific surface area and clay content to shrink-swell potential of soils having different clay mineralogical compositions. Can. J. Soil Sci. 58:159-166.

Sando, W.J. 1956. Nomenclature of Lower Ordovician rocks of Washington County, Maryland. Geol. Soc. Am. Bull. 67:935-938.

Sawhney, B.L. 1989. Interstratification in layer silicates. p. 789-828. In J.B. Dixon and S.B. Weed (ed.) Minerals in soil environments. $2^{\text {nd }}$ ed. SSSA Book Ser. No. 1. SSSA, Madison, WI.

Schafer, W.M. and M.J. Singer. 1976. Influence of physical and mineralogical properties on swelling of soils in Yolo County, California. Soil Sci. Soc. Am. J. 40:557-562. 
Schulze, D.G. 1989. An introduction to soil mineralogy. p. 1-34. In J.B. Dixon and S.B. Weed (ed.) Minerals in soil environments. $2^{\text {nd }}$ ed. SSSA Book Ser. No. 1. SSSA, Madison, WI.

Schwertmann, U and R.M. Taylor. 1989. Iron oxides. p. 379-438. In J.B. Dixon and S.B. Weed (ed.) Minerals in soil environments. $2^{\text {nd }}$ ed. SSSA Book Ser. No. 1. SSSA, Madison, WI.

Schwertmann, U. 1993. Relations between iron oxides, soil color, and soil formation. p. 51-69. In J.M. Bigham and E.J. Ciolkosz (ed.) Soil color. SSSA Spec. Publ. No. 31. SSSA, Madison, WI.

Soil Survey Staff. 1975. Soil taxonomy: A basic system of soil classification for making and interpreting soil surveys. USDA-SCS Agric. Handb. No. 436. U.S. Gov. Print. Office, Washington, DC.

Soil Survey Division Staff. 1993. Soil survey manual. USDA Handb. No. 18. U.S. Gov. Print. Office, Washington, DC.

Soil Survey Staff. 1995. Soil survey laboratory information manual. Soil Survey Investigations Report No. 45. Version 1.0. National Soil Survey Center, Lincoln, NB.

Soil Survey Staff. 1996. Soil survey laboratory methods manual. Soil Survey Investigations Report No. 42. Version 3.0. National Soil Survey Center, Lincoln, NB.

Soil Survey Staff. 1999. Soil taxonomy: A basic system of soil classification for making and interpreting soil surveys. USDA-NRCS Agric. Handb. No. 436. $2^{\text {nd }}$ ed. U.S. Gov. Print. Office, Washington, DC.

Soil Survey Staff. 2004. Soil survey laboratory methods manual. Soil Survey Investigations Report No. 42. Version 4.0. National Soil Survey Center, Lincoln, NB.

Soil Survey Staff. 2006. Keys to soil taxonomy. USDA-NRCS. $10^{\text {th }}$ ed. U.S. Gov. Print. Office, Washington, DC

Soil Survey Staff, Natural Resources Conservation Service, United States Department of Agriculture. 2007. National Soil Survey Handbook, title 430-VI. [Online]. Available at http://soils.usda.gov/technical/handbook/ (verified 27 Aug. 2008).

Soil Survey Staff, Natural Resources Conservation Service, United States Department of Agriculture. 2008. Official Soil Series Descriptions [Online]. Available at http://soils.usda.gov/technical/classification/osd/index.html (verified 28 Feb. 2009). 
Sposito, G. 1973. Volume changes in swelling clays. Soil Sci. 115:315-320.

Sposito, G., R. Prost and J.P. Gaultier. 1983. Infrared spectroscopic study of adsorbed water on reduced-charge Na/Li-montmorillonites. Clays Clay Miner. 31:9-16.

Thomas, P.J. 1998. Quantifying properties and variability of expansive soils in selected map units. Ph.D. diss. Virginia Polytechnic Inst \& State Univ., Blacksburg.

Thomas, P.J., J.C. Baker, L.W. Zelazny, and D.R. Hatch. 2000a. Relationship of map unit variability to shrink-swell indicators. Soil Sci. Soc. Am. J. 64:262-268.

Thomas, P.J., J.C. Baker, and L.W. Zelazny. 2000b. An expansive soil index for predicting shrink-swell potential. Soil Sci. Soc. Am. J. 64:268-274.

Tunney, J. 1970. The influence of saran resin coatings on swelling of natural soil clods. Soil Sci. 109:254-256.

U.S. Census Bureau, Population Division. 2008a. Cumulative estimates of population change for counties of West Virginia and county rankings: April 1, 2000 to July 1, 2007 (CO-EST2007-02-54) [Online]. Available at http://www.census.gov/popest/counties/tables/CO-EST2007-02-54.xls (Release date 20 Mar. 2008; verified 28 Feb. 2009).

U.S. Census Bureau, Population Division. 2008b. Population estimates for the 100 fastest growing U.S. counties with 10,000 or more population in 2007: April 1, 2000 to July 1, 2007 (CO-EST2007-08) [Online]. Available at http://www.census.gov/popest/counties/tables/CO-EST2007-08.xls (Release date 20 Mar. 2008; verified 28 Feb. 2009).

van Eck, W.A. 1979. Soils. p. 12-15. In Water in the Great Valley: People-problemsdecisions. Proc. of the 1979 Fall Public Meeting. Published by Interstate Commission on the Potomac River Basin. Rockville, MD.

Viani, B.E., P.F. Low, and C.B. Roth. 1983. Direct measurement of relation between interlayer force and interlayer distance in the swelling of montmorillonite. J. Colloid Interface Sci. 96:229-244.

Yaalon, D.H. and D. Kalmar. 1972. Vertical movement in an undisturbed soil: Continuous measurement of swelling and shrinkage with a sensitive apparatus. Geoderma. 8:231-240.

Yerima, B.P.K., F.G. Calhoun, A.L. Senkayi, and J.B. Dixon. 1985. Occurrence of interstratified kaolinite-smectite in El Salvador Vertisols. Soil Sci. Soc. Am. J. 49:462-466. 
Yerima, B.P.K., L.P. Wilding, F.G. Calhoun, and C.T. Hallmark. 1987. Volcanic ashinfluenced Vertisols and associated Mollisols of El Salvador: Physical, chemical and morphological properties. Soil Sci. Soc. Am. J. 51: 699-708.

Yerima, B.P.K., L.P. Wilding, C.T. Hallmark, and F.G. Calhoun. 1989. Statistical relationships among selected properties of Northern Cameroon Vertisols and associated Alfisols. Soil Sci. Soc. Am. J. 53:1758-1763. 
Appendices 


\section{Appendix A}

\section{A.1. Carbo Official Series Description}

A.2. Carbo \#1 Site and Profile Description
A.3. Carbo \#1 Characterization Data

A.4. Carbo \#2 Site and Profile Description

A.5. Carbo \#2 Characterization Data

A.6. Carbo \#3 Site and Profile Description

A.7. Carbo \#3 Characterization Data 


\section{A.1. Carbo Official Series Description}

LOCATION CARBO

VA+TN WV

Established Series

Rev. DDR

$12 / 1999$

\section{CARBO SERIES}

Soils of the Carbo series are moderately deep, well drained, and slowly permeable. They formed in material weathered from limestone bedrock. They are nearly level to very steep soils on uplands in the Appalachian Ridges and Valleys. Mean annual temperature is about 55 degrees F., and mean annual precipitation is about 40 inches. Slopes range from 2 to 65 percent.

TAXONOMIC CLASS: Very-fine, mixed, active, mesic Typic Hapludalfs

TYPICAL PEDON: Carbo silt loam - in a cultivated field on a 10 percent slope. (Colors are for moist soil.)

Ap--0 to 10 inches; dark brown (10YR 4/3) silt loam; moderate fine granular structure; friable; many fine and very fine roots; few fine pores; many worm casts and channels; 2 percent iron oxide concretions up to $1 / 4$ inch in diameter; slightly acid; abrupt smooth boundary. ( 0 to 10 inches thick)

Bt1--10 to 25 inches; strong brown (7.5YR 5/6) clay; common coarse distinct yellowish brown (10YR 5/8) mottles; moderate medium subangular blocky structure; firm, sticky, very plastic; common fine and very fine roots; few fine pores; thick continuous clay films on faces of peds; common worm casts and channels; 2 percent iron oxide concretions up to $1 / 2$ inch in diameter; few black (N2/0) manganese oxide stains; moderately acid; clear smooth boundary.

Bt2--25 to 32 inches; dark yellowish brown (10YR 4/4) clay; weak medium subangular blocky structure; firm, sticky; very plastic; few very fine roots; few fine pores; thick continuous clay films on faces of peds; few worm casts and channels; 2 percent iron oxide concretions up to $1 / 4$ inch in diameter; common black $(\mathrm{N} 2 / 0)$ manganese oxide stains; mildly alkaline; abrupt wavy boundary. (combined thickness of the Bt horizon range 10 to 35 inches )

R--32 inches; limestone bedrock.

TYPE LOCATION: Rockingham County, Virginia; about 3.5 miles southwest of New Market, 1,200 feet north of intersection of Routes 796 and 620.

RANGE IN CHARACTERISTICS: Solum thickness and depth to bedrock range from 20 to 40 inches. Rock fragments, usually shale, limestone, or quartz, range from 0 to 10 
percent by volume in the $\mathrm{A}$ horizon and from 0 to 15 percent in the $\mathrm{B}$ and $\mathrm{C}$ horizons. Oxide concretions range from 0 to 10 percent throughout the solum, and some pedons have a few secondary carbonate concretions in the lower part of the $\mathrm{B}$ and $\mathrm{C}$ horizons. The soil ranges from very strongly acid through neutral in the A horizon and from moderately acid through mildly alkaline in the $\mathrm{B}$ and $\mathrm{C}$ horizons.

The A horizon has hue of 7.5YR or 10YR, value of 3 through 5, and chroma of 2 through 6. Where value and chroma are 3 or less, it is less than 6 inches thick. It is silt loam or silty clay loam.

The Ap horizon has hue of $7.5 \mathrm{YR}$ or $10 \mathrm{YR}$, value of 4 or 5 , and chroma of 3 through 6 . It is silt loam or silty clay loam, and silty clay or clay in eroded areas.

The BA horizon, where present, has hue of 7.5YR or 10YR, value of 3 through 6 , and chroma of 4 through 8 . It is silt loam, clay loam, or silty clay loam.

The Bt horizon has hue of 5YR through 10YR, value of 4 through 6 , and chroma of 4 through 8. Hue of 5YR is restricted to the lower part of the Bt horizon. Mottles, streaks, or patches of colors are in some pedons. The Bt horizon is clay.

The BC horizon, where present, have hue of $7.5 \mathrm{YR}$ through $2.5 \mathrm{Y}$, value of 4 or 5 , and chroma of 4 through 8 . The $\mathrm{BC}$ horizon is clay or silty clay.

The $\mathrm{C}$ horizon, where present, have hue of $7.5 \mathrm{YR}$ through $2.5 \mathrm{Y}$, value of 4 or 5 , and chroma of 4 through 8 . Some pedons are mottled. The $\mathrm{C}$ horizon are clay or silty clay.

The $\mathrm{R}$ horizon is limestone or interbedded limestone and shale.

COMPETING SERIES: These are the Bardley, Chilhowie, Endcav, Gatewood, Niangua, and Oshkosh series. Bardley soils have hue of 5YR or redder throughout the B horizon. Chilhowie soils have a thinner solum and contain more rock fragments in the lower part of the series control section. Endcav and Oshkosh soils do not have bedrock within a depth of 40 inches. Gatewood soils have rock fragments larger than 3 inches and have more rock fragments than the Carbo soils.

GEOGRAPHIC SETTING: Carbo soils are gently sloping to very steep upland soils in the Appalachian Ridges and Valleys. Slopes range from 2 to 65 percent. They formed in material weathered from argillaceous limestone and, in some areas, limestone interbedded with small amounts of shale. Rock outcrops and/or sinkholes are in many areas. Mean annual temperature range from 54 to 57 degrees F, and mean annual precipitation range from 38 to 44 inches near the type location. Elevation ranges from 600 to 2,500 feet.

GEOGRAPHICALLY ASSOCIATED SOILS: These include the competing Chilhowie and Endcav soils and the Faywood, Frederick, Guernsey, Lodi, Muse, Oaklet, Opequon, Pagebrook, Poplimento, and Swimley series. Faywood, Lodi, Muse, and 
Poplimento soils have less than 60 percent clay in the particle-size control section. In addition, Lodi, and Muse soils have less than 35 percent base saturation. Frederick, Oaklet, and Swimley soils have sola more than 60 inches thick. Guernsey and Pagebrook soils are on lower parts of the landscape and are not as well drained. Opequon soils have bedrock within 20 inches of the surface.

DRAINAGE AND PERMEABILITY: Well drained, medium to very rapid runoff; slow permeability.

USE AND VEGETATION: The clear areas are used for cropland or pasture. The crops include corn, small grain, and hay. Forested areas consist of northern red oak, yellow poplar, hickory, maple, black walnut, locust, eastern red cedar, and Virginia pine.

DISTRIBUTION AND EXTENT: Virginia, Tennessee, and West Virginia. The series is of moderate extent.

MLRA OFFICE RESPONSIBLE: Morgantown, West Virginia

SERIES ESTABLISHED: Russell County, Virginia, 1940.

REMARKS: Diagnostic horizons and other features recognized in this pedon are:

a. Ochric epipedon - the zone from 0 to 10 inches (Ap horizon).

b. Argillic horizon - the zone between 10 and 32 inches (Bt horizon). c. Lithic contact hard bedrock at 32 inches.

$\mathrm{SIR}=\mathrm{VA} 0019$

MLRA $=125,128,147$

REVISED=12/13/93, MHC

National Cooperative Soil Survey

U.S.A. 


\section{A.2. Carbo \#1 Site and Profile Description}

Sampled as: Carbo

Lab \#: S99-WV003-008 -- Carbo \#1

Location: North of Rt. 45 at Blairton Quarry - Altair Farm - Berkeley County

Latitude: $39^{\circ} 27^{\prime} 58^{\prime \prime} \mathrm{N}$; Longitude: $77^{\circ} 54^{\prime} 21^{\prime \prime} \mathrm{W}$

Physiography: Valley and Ridge Province

Land Use and Vegetation: Hayfield with grasses and legumes.

Parent Material: Residual - Chambersburg Limestone

Described by: John Sencindiver, James Bell, Brian Cooley, Steve Baker and Jason

Knopp on June 4, 1999

Ap1 -0 to $7 \mathrm{~cm}$ (0 to 3 inches); dark grayish brown (10YR 4/2) silty clay loam; moderate very fine and fine granular structure; very friable; many very fine and fine roots; 2 percent channers; abrupt smooth boundary.

Ap2 - 7 to $19 \mathrm{~cm}$ (3 to 7.5 inches); dark yellowish brown (10YR 4/6) silty clay loam; weak medium subangular blocky structure; firm; sticky and plastic; few medium and common very fine and fine roots; few fine iron and manganese concentrations; coatings of brown (10YR 4/3) and dark brown (10YR 3/3) on ped faces and in root channels; 2 percent channers; abrupt wavy boundary.

$\mathrm{Bt}-19$ to $26 \mathrm{~cm}$ (7.5 to 10 inches); brown (7.5YR 4/4) clay; moderate medium subangular blocky structure; firm; very sticky and very plastic; few very fine and fine roots; common discontinuous distinct clay films; 1 percent rock fragments; abrupt wavy boundary.

Btss $1-26$ to $51 \mathrm{~cm}$ (10 to 20 inches); yellowish brown (10YR 5/6) clay; moderate medium subangular blocky structure; firm; very sticky and very plastic; few very fine and fine roots; few manganese stains and concentrations; many continuous distinct clay films; common slickensides 5 to $20 \mathrm{~cm}$; 1 percent rock fragments; clear wavy boundary.

Btss 2 - 51 to $61 \mathrm{~cm}$ (20 to 24 inches); mixed brownish yellow (10YR 6/8) and yellowish brown (10YR 5/6) clay; weak medium subangular blocky structure; firm; very sticky and very plastic; few very fine and fine roots concentrated at bedrock; common fine and medium manganese coatings and concentrations; common discontinuous distinct clay films; few slickensides; 5 percent limestone fragments; abrupt wavy boundary.

$\mathrm{R}-61$ to $70+$ (24 to 27.5 inches); limestone bedrock 
Notes: Cracks with a width of 2 to $5 \mathrm{~mm}$ exist 13 to $33 \mathrm{~cm}$ apart beginning at the surface and extending to bedrock. Cracks are coated with A horizon material from top to bottom. Cracks are widest in the Ap and Bt horizons and narrow in the Btss horizons. One crack was $2 \mathrm{~cm}$ wide in the Ap2 horizon. Common slickensides in the Btss 1 horizon are intersecting near the base of the horizon at 25 to 45 degrees from the horizontal. 


\section{A.3. Carbo \#1 Characterization Data}

\begin{tabular}{|c|c|c|c|c|c|c|c|c|c|}
\hline \multirow{3}{*}{ Horizon } & \multirow{3}{*}{ Depth } & \multicolumn{8}{|c|}{ Particle Size } \\
\hline & & \multicolumn{3}{|c|}{ Total } & \multicolumn{5}{|c|}{ Sand } \\
\hline & & Sand & Silt & Clay & V. Coarse & Coarse & Medium & Fine & V. Fine \\
\hline & $\mathrm{cm}$ & & & & $--\%$ & & & & \\
\hline Ap1 & $0-7$ & 10.0 & 43.1 & 46.9 & 1.1 & 0.9 & 1.0 & 2.1 & 4.9 \\
\hline Ap2 & $7-19$ & 11.0 & 41.1 & 47.9 & 1.8 & 1.3 & 1.0 & 2.1 & 4.8 \\
\hline $\mathrm{Bt}$ & $19-26$ & 8.3 & 38.2 & 53.5 & 1.4 & 1.0 & 1.0 & 1.5 & 3.4 \\
\hline Btss1 & $26-51$ & 4.6 & 31.8 & 63.6 & 0.7 & 0.6 & 0.5 & 0.8 & 2.0 \\
\hline Btss2 & $51-61$ & 6.2 & 29.1 & 64.7 & 0.2 & 0.3 & 0.4 & 1.3 & 4.0 \\
\hline
\end{tabular}

\begin{tabular}{|c|c|c|c|c|c|c|c|}
\hline \multirow{3}{*}{ Horizon } & \multirow{3}{*}{ Depth } & \multicolumn{4}{|c|}{ Bulk Density } & \multirow{2}{*}{\multicolumn{2}{|c|}{ Atterberg Limits }} \\
\hline & & \multicolumn{2}{|c|}{ Oven-Dry } & \multicolumn{2}{|c|}{33 kPA Desorption } & & \\
\hline & & $\mathrm{Db}>2 \mathrm{~mm}$ & $\mathrm{Db}<2 \mathrm{~mm}$ & $\mathrm{Db}>2 \mathrm{~mm}$ & $\mathrm{Db}<2 \mathrm{~mm}$ & Liquid Limit & Plasticity Index \\
\hline & $\mathrm{cm}$ & & $-g$ & $n^{-3}-\cdots$ & 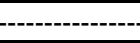 & & \\
\hline Ap1 & $0-7$ & 1.68 & 1.62 & 1.52 & 1.45 & 64 & 32 \\
\hline Ap2 & $7-19$ & 1.85 & 1.83 & 1.64 & 1.61 & 50 & 29 \\
\hline $\mathrm{Bt}$ & $19-26$ & 1.83 & 1.82 & 1.57 & 1.55 & 54 & 35 \\
\hline Btss1 & $26-51$ & 1.86 & 1.85 & 1.56 & 1.54 & 61 & 39 \\
\hline Btss2 & $51-61$ & 1.86 & 1.86 & 1.59 & 1.59 & 60 & 39 \\
\hline
\end{tabular}

\begin{tabular}{|c|c|c|c|c|c|c|}
\hline \multirow{2}{*}{ Horizon } & \multirow{2}{*}{ Depth } & \multirow{2}{*}{$\begin{array}{c}\text { Rock } \\
\text { Fragments by } \\
\text { Wt. }\end{array}$} & \multicolumn{3}{|c|}{ Water Retention } & \multirow{2}{*}{ COLE } \\
\hline & & & $33 \mathrm{kPA}$ & $1500 \mathrm{kPA}$ & \multirow{2}{*}{$\frac{\text { WRD }}{\mathrm{cm} \mathrm{cm}^{-1}}$} & \\
\hline & $\mathrm{cm}$ & 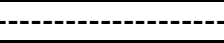 & ----\%--- & - & & \\
\hline Ap1 & $0-7$ & 3.0 & 32.1 & 17.9 & 0.20 & 0.03 \\
\hline Ap2 & 7-19 & 10.9 & 27.6 & 15.7 & 0.19 & 0.05 \\
\hline $\mathrm{Bt}$ & $19-26$ & 3.5 & 31.4 & 18.2 & 0.20 & 0.05 \\
\hline Btss1 & $26-51$ & 1.5 & 34.8 & 20.1 & 0.22 & 0.08 \\
\hline Btss2 & $51-61$ & 0.1 & 35.1 & 20.5 & 0.22 & 0.06 \\
\hline
\end{tabular}

\begin{tabular}{|c|c|c|c|c|c|c|c|c|c|c|c|c|}
\hline \multirow{2}{*}{ Horizon } & \multirow{2}{*}{ Depth } & \multicolumn{6}{|c|}{ Extractable } & \multicolumn{2}{|c|}{ CEC } & \multirow{2}{*}{ ECEC } & \multicolumn{2}{|c|}{ Base Saturation } \\
\hline & & $\mathrm{Ca}$ & $\mathrm{Mg}$ & $\mathrm{Na}$ & K & Acidity & $\mathrm{Al}$ & CEC-8.2 & CEC-7 & & CEC-8.2 & CEC-7 \\
\hline & $\mathrm{cm}$ & \multicolumn{9}{|c|}{$-\mathrm{cmol}_{\mathrm{C}} \mathrm{kg}^{-1}-1$} & \multicolumn{2}{|c|}{--------\%"------- } \\
\hline Ap1 & $0-7$ & 22.0 & 1.9 & $\mathrm{BDL}^{*}$ & 0.6 & 6.1 & $\overline{--}$ & 30.6 & 26.8 & -- & 80.1 & 91.4 \\
\hline Ap2 & $7-19$ & 18.9 & 1.0 & 0.1 & 0.3 & 2.7 & $\overline{--}$ & 23.0 & 22.7 & -- & 88.3 & 89.4 \\
\hline $\mathrm{Bt}$ & $19-26$ & 20.3 & 1.1 & 0.1 & 0.3 & 3.1 & -- & 24.9 & 25.3 & -- & 87.6 & 86.2 \\
\hline Btss1 & $26-51$ & 23.8 & 1.1 & 0.1 & 0.4 & 3.9 & -- & 29.3 & 29.4 & -- & 86.7 & 86.4 \\
\hline Btss2 & 51-61 & 24.6 & 0.9 & 0.1 & 0.3 & 1.6 & -- & 27.5 & 27.9 & -- & 94.2 & 92.8 \\
\hline
\end{tabular}

*BDL - Below Detectable Limit 


\begin{tabular}{|c|c|c|c|c|c|c|c|c|}
\hline \multirow{2}{*}{ Horizon } & \multirow{2}{*}{ Depth } & \multirow{2}{*}{ Al Saturation } & \multicolumn{3}{|c|}{ Total } & \multirow{2}{*}{$\begin{array}{c}\text { Extractable } \\
\mathrm{Mn}\end{array}$} & \multicolumn{2}{|c|}{$\mathrm{pH}$} \\
\hline & & & Carbon & Sulfur & Nitrogen & & 1:1 Water & $1: 2 \mathrm{CaCl}_{2}$ \\
\hline & $\mathrm{cm}$ & 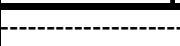 & -----\% & & -2 & $\mathrm{mg} \mathrm{kg}^{-1}$ & & \\
\hline Ap1 & $0-7$ & -- & 4.46 & 0.05 & 0.34 & -- & 6.1 & 5.7 \\
\hline Ap2 & $7-19$ & -- & 1.19 & 0.01 & 0.11 & -- & 6.8 & 6.0 \\
\hline $\mathrm{Bt}$ & $19-26$ & -- & 0.72 & 0.01 & $\overline{B D L}$ & -- & 6.4 & 6.0 \\
\hline Btss1 & $26-51$ & -- & 0.47 & BDL & 0.03 & -- & 6.9 & 6.1 \\
\hline Btss2 & $51-61$ & -- & 0.36 & BDL & 0.04 & -- & 7.1 & 6.4 \\
\hline
\end{tabular}

\begin{tabular}{|c|c|c|c|c|c|c|c|c|}
\hline \multirow{2}{*}{ Horizon } & \multirow{2}{*}{ Depth } & \multicolumn{7}{|c|}{ Total Elemental Analysis } \\
\hline & & $\mathrm{Fe}$ & $\mathrm{Mn}$ & $\mathrm{Al}$ & $\mathrm{Ca}$ & $\mathrm{Mg}$ & $\mathrm{Na}$ & $\mathrm{K}$ \\
\hline & $\mathrm{cm}$ & & & & $\mathrm{mg} \mathrm{kg}^{-1}$ & & & \\
\hline Ap1 & $0-7$ & 24038.5 & 480.3 & 58908.0 & 5368.6 & 4471.3 & 2819.0 & 1464.1 \\
\hline Ap2 & $7-19$ & 21929.4 & 397.1 & 36321.6 & 3478.9 & 2826.6 & 3029.8 & 1228.2 \\
\hline $\mathrm{Bt}$ & $19-26$ & 31657.9 & 598.9 & 43311.5 & 4163.6 & 3081.3 & 2612.6 & 1283.4 \\
\hline Btss1 & $26-51$ & 32795.1 & 898.8 & 43970.0 & 4918.3 & 3037.1 & 2485.1 & 1437.9 \\
\hline Btss2 & $51-61$ & 24474.2 & 696.7 & 42483.0 & 5001.7 & 2931.3 & 1647.9 & 1351.4 \\
\hline
\end{tabular}

\begin{tabular}{|c|c|c|c|c|c|c|c|c|}
\hline \multirow{2}{*}{ Horizon } & \multirow{2}{*}{ Depth } & \multicolumn{7}{|c|}{ Total Elemental Analysis } \\
\hline & & $P$ & $\mathrm{Si}$ & $\mathrm{Cu}$ & $\mathrm{Zn}$ & $\mathrm{Ni}$ & As & Co \\
\hline & $\mathrm{cm}$ & & & & $\mathrm{mg} \mathrm{kg}^{-1}$ & & & -- \\
\hline Ap1 & $0-7$ & 584.4 & 146818.0 & 33.3 & 100.6 & 9.4 & 7.0 & 87.6 \\
\hline Ap2 & $7-19$ & 363.8 & 92042.2 & 41.7 & 391.0 & 14.9 & 9.3 & 82.9 \\
\hline $\mathrm{Bt}$ & $19-26$ & 258.9 & 133920.2 & 45.2 & 254.9 & 23.3 & 11.2 & 97.3 \\
\hline Btss1 & $26-51$ & 250.0 & 127436.3 & 47.6 & 140.8 & 37.6 & 13.7 & 102.1 \\
\hline Btss2 & $51-61$ & 317.8 & 122547.5 & 40.8 & 298.9 & 28.8 & 8.7 & 74.4 \\
\hline
\end{tabular}

\begin{tabular}{|c|c|c|c|c|c|c|c|c|c|c|c|}
\hline \multirow{2}{*}{ Horizon } & \multirow{2}{*}{ Depth } & \multicolumn{10}{|c|}{ Total Elemental Analysis } \\
\hline & & $\mathrm{Se}$ & $\mathrm{Cd}$ & $\mathrm{Pb}$ & $\mathrm{Ba}$ & $\mathrm{Ag}$ & $\mathrm{Hg}$ & Mo & $\mathrm{Cr}$ & $\mathrm{Be}$ & V \\
\hline & $\mathrm{cm}$ & \multicolumn{10}{|c|}{6170} \\
\hline Ap1 & $0-7$ & $\mathrm{BDL}$ & $\mathrm{BDL}$ & 17.4 & 647.3 & $\mathrm{BDL}$ & $\mathrm{BDL}$ & $\mathrm{BDL}$ & 6.0 & 2.1 & 40.6 \\
\hline Ap2 & $7-19$ & 0.2 & 0.1 & 16.4 & 462.1 & $\mathrm{BDL}$ & BDL & BDL & 9.6 & 2.1 & 47.0 \\
\hline $\mathrm{Bt}$ & $19-26$ & 0.3 & 0.1 & 15.2 & 493.6 & BDL & BDL & $\mathrm{BDL}$ & 19.2 & 3.2 & 71.7 \\
\hline Btss1 & $26-51$ & 0.2 & 0.4 & 16.5 & 608.3 & $\mathrm{BDL}$ & $\overline{B D L}$ & $\mathrm{BDL}$ & 26.4 & 3.3 & 86.8 \\
\hline Btss2 & $51-61$ & 0.3 & $\overline{B D L}$ & 23.1 & 689.2 & $\overline{B D L}$ & $\overline{B D L}$ & $\mathrm{BDL}$ & 15.4 & 2.8 & 68.5 \\
\hline
\end{tabular}

\begin{tabular}{|c|c|c|c|c|c|c|c|}
\hline Horizon & Depth & \multicolumn{6}{|c|}{ Clay Mineralogy } \\
\hline & $\mathrm{cm}$ & & & 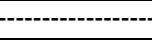 & -peak size---- & & \\
\hline $\mathrm{Bt}$ & $19-26$ & Mica - 2 & Vermiculite - 2 & Kaolinite - 2 & Geothite - 1 & Quartz - 1 & \\
\hline Btss1 & $26-51$ & Mica - 2 & Kaolinite - 2 & Quartz - 1 & Vermiculite - 1 & Montmorillonite-Mica - 1 & Geothite - 1 \\
\hline
\end{tabular}

Relative Peak Size: 5 - Very Large (>50\%) 4 - Large (30-50\%) 3 - Medium (10-30\%)

$$
2 \text { - Small (3-10\%) } \quad 1 \text { - Very Small }(<3 \%)
$$




\section{A.4. Carbo \#2 Site and Profile Description}

Sampled as: Carbo

Lab \#: S99-WV003-006 -- Carbo \#2

Location: East of U.S. Rt. 11 on Breeze Hill Farm - Stewart Property - Tabler Station Berkeley County

Latitude: $39^{\circ} 23^{\prime} 27^{\prime \prime} \mathrm{N}$; Longitude: $78^{\circ} 00^{\prime} 24^{\prime \prime} \mathrm{W}$

Physiography: Valley and Ridge Province

Elevation: $161.1 \mathrm{~m} \pm 8.2 \mathrm{~m}(530 \mathrm{ft} . \pm 27 \mathrm{ft}$. $)$

Land use and vegetation: Pasture field with bluegrass, tall fescue and Russian thistle.

Parent Material: Residual - Chambersburg Limestone

Described by: John Sencindiver, James Bell, Ron Howard, Jason Knopp and Bill Bates on July 8, 1999

A - 0 to $7 \mathrm{~cm}$ (0 to 3 inches); dark brown (10YR 3/3) heavy silt loam; moderate medium granular structure; friable; slightly sticky and slightly plastic; many very fine and fine roots; clear wavy boundary.

Ap - 7 to $21 \mathrm{~cm}$ (3 to 8.5 inches); brown (10YR 4/3) silty clay loam; moderate fine and medium subangular blocky structure; friable; slightly sticky and slightly plastic; common very fine and fine roots; 5 percent limestone channers; abrupt wavy boundary.

Btss1 - 21 to $60 \mathrm{~cm}$ (8.5 to 23.5 inches); dark yellowish brown (10YR 4/6) clay; weak coarse prismatic structure parting to moderate medium and coarse subangular blocky; very hard (dry); firm (moist); very sticky and very plastic; few very fine and fine roots; common fine and medium brown (10YR 4/3) organic coatings on ped faces and in pores; many continuous distinct clay films on ped faces and in pores; many continuous prominent slickensides 5 to $30+\mathrm{cm}$; clear wavy boundary.

Btss 2 - 60 to $72 \mathrm{~cm}$ (23.5 to 28.5 inches); dark yellowish brown (10YR 4/6) clay; few fine and medium reddish brown (5YR 4/4) mottles; moderate medium subangular blocky structure; hard (dry); firm (moist); very sticky and very plastic; very few very fine and fine roots; common fine and medium brown (10YR 4/3) organic coatings on ped faces and in pores; many continuous distinct clay films; common slickensides 5 to $15 \mathrm{~cm}$; 5 percent gravel; abrupt wavy boundary.

$\mathrm{R}-72+\mathrm{cm}(28.5+$ inches $)$; limestone bedrock

Notes: Cracks with a width of $2 \mathrm{~mm}$ to $1.5 \mathrm{~cm}$ exist 20 to $40 \mathrm{~cm}$ apart beginning at the surface and extending to bedrock. Intersecting slickensides were found in the Btss 1 during sampling. 


\section{A.5. Carbo \#2 Characterization Data}

\begin{tabular}{|c|c|c|c|c|c|c|c|c|c|}
\hline \multirow{3}{*}{ Horizon } & \multirow{3}{*}{ Depth } & \multicolumn{8}{|c|}{ Particle Size } \\
\hline & & \multicolumn{3}{|c|}{ Total } & \multicolumn{5}{|c|}{ Sand } \\
\hline & & Sand & Silt & Clay & V. Coarse & Coarse & Medium & Fine & V. Fine \\
\hline & $\mathrm{cm}$ & & & & & & & & \\
\hline A & $0-7$ & 5.9 & 52.1 & 42.0 & 0.2 & 0.7 & 1.2 & 1.3 & 2.5 \\
\hline$A p$ & $7-21$ & 7.2 & 50.6 & 42.2 & 0.9 & 1.1 & 1.4 & 1.4 & 2.4 \\
\hline Btss1 & $21-60$ & 3.0 & 29.7 & 67.3 & 0.3 & 0.3 & 0.5 & 0.7 & 1.2 \\
\hline Btss2 & $60-72$ & 7.7 & 21.2 & 71.1 & 2.1 & 1.7 & 1.3 & 1.2 & 1.4 \\
\hline
\end{tabular}

\begin{tabular}{|c|c|c|c|c|c|c|c|}
\hline \multirow{3}{*}{ Horizon } & \multirow{3}{*}{ Depth } & \multicolumn{4}{|c|}{ Bulk Density } & \multirow{2}{*}{\multicolumn{2}{|c|}{ Atterberg Limits }} \\
\hline & & \multicolumn{2}{|c|}{ Oven-Dry } & \multicolumn{2}{|c|}{33 kPA Desorption } & & \\
\hline & & $\mathrm{Db}>2 \mathrm{~mm}$ & $\mathrm{Db}<2 \mathrm{~mm}$ & $\mathrm{Db}>2 \mathrm{~mm}$ & $\mathrm{Db}<2 \mathrm{~mm}$ & Liquid Limit & Plasticity Index \\
\hline & $\mathrm{cm}$ & - & $--g$ & $n^{-3}-\ldots$ & & & \\
\hline $\bar{A}$ & $0-7$ & 1.39 & 1.39 & 1.22 & 1.22 & 62 & 30 \\
\hline Ap & $7-21$ & 1.72 & 1.71 & 1.58 & 1.58 & 43 & 22 \\
\hline Btss1 & $21-60$ & 1.73 & 1.73 & 1.46 & 1.46 & 58 & 36 \\
\hline Btss2 & $60-72$ & 1.78 & 1.71 & 1.55 & 1.47 & 62 & 38 \\
\hline
\end{tabular}

\begin{tabular}{|c|c|c|c|c|c|c|}
\hline \multirow{2}{*}{ Horizon } & \multirow{2}{*}{ Depth } & \multirow{2}{*}{$\begin{array}{c}\text { Rock } \\
\text { Fragments by } \\
\text { Wt. }\end{array}$} & \multicolumn{3}{|c|}{ Water Retention } & \multirow{2}{*}{ COLE } \\
\hline & & & $33 \mathrm{kPA}$ & $1500 \mathrm{kPA}$ & \multirow{2}{*}{$\frac{\text { WRD }}{\mathrm{cm} \mathrm{cm}^{-1}}$} & \\
\hline & $\mathrm{cm}$ & ------------------ & ----\%---. & ----------. & & \\
\hline$A$ & $0-7$ & 0.1 & 38.6 & 17.5 & 0.26 & 0.04 \\
\hline Ap & $7-21$ & 0.7 & 27.5 & 13.8 & 0.21 & 0.03 \\
\hline Btss1 & $21-60$ & 0.1 & 36.7 & 20.9 & 0.23 & 0.06 \\
\hline Btss2 & $60-72$ & 6.9 & 40.1 & 23.5 & 0.23 & 0.06 \\
\hline
\end{tabular}

\begin{tabular}{|c|c|c|c|c|c|c|c|c|c|c|c|c|}
\hline \multirow{2}{*}{ Horizon } & \multirow{2}{*}{ Depth } & \multicolumn{6}{|c|}{ Extractable } & \multicolumn{2}{|c|}{ CEC } & \multirow{2}{*}{ ECEC } & \multicolumn{2}{|c|}{ Base Saturation } \\
\hline & & $\mathrm{Ca}$ & $\mathrm{Mg}$ & $\mathrm{Na}$ & $\mathrm{K}$ & Acidity & $\mathrm{Al}$ & CEC-8.2 & CEC-7 & & CEC-8.2 & CEC-7 \\
\hline & $\mathrm{cm}$ & & & & & $-\mathrm{cmol}_{\mathrm{c}} \mathrm{k}$ & & & & & & 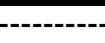 \\
\hline $\bar{A}$ & $0-7$ & 18.5 & 1.8 & 0.1 & 1.3 & 6.6 & $\overline{--}$ & 28.3 & 24.6 & -- & 76.7 & 88.2 \\
\hline Ap & $7-21$ & 15.0 & 0.9 & 0.1 & 0.2 & 5.4 & -- & 21.6 & 19.8 & -- & 75.0 & 81.8 \\
\hline Btss1 & $21-60$ & 22.4 & 0.8 & 0.1 & 0.3 & 6.2 & -- & 29.8 & 29.0 & -- & 79.2 & 81.4 \\
\hline Btss2 & $60-72$ & 41.1 & 0.6 & 0.1 & 0.3 & 2.2 & -- & 44.3 & 33.2 & -- & 95.0 & 126.8 \\
\hline
\end{tabular}

\begin{tabular}{|c|c|c|c|c|c|c|c|c|}
\hline \multirow{2}{*}{ Horizon } & \multirow{2}{*}{ Depth } & \multirow{2}{*}{ Al Saturation } & \multicolumn{3}{|c|}{ Total } & \multirow{2}{*}{$\begin{array}{c}\text { Extractable } \\
\mathrm{Mn}\end{array}$} & \multicolumn{2}{|c|}{$\mathrm{pH}$} \\
\hline & & & Carbon & Sulfur & Nitrogen & & 1:1 Water & $1: 2 \mathrm{CaCl}_{2}$ \\
\hline & $\mathrm{cm}$ & & $\overline{---\%-}$ & & & $\mathrm{mg} \mathrm{kg}^{-1}$ & & \\
\hline A & $0-7$ & -- & 4.65 & 0.06 & 0.31 & -- & 6.2 & 5.8 \\
\hline Ap & $7-21$ & -- & 1.62 & 0.02 & 0.05 & -- & 6.4 & 5.7 \\
\hline Btss1 & $21-60$ & -- & 0.54 & 0.01 & 0.01 & -- & 6.5 & 5.8 \\
\hline Btss2 & $60-72$ & -- & 0.90 & BDL & 0.01 & -- & 7.1 & 6.6 \\
\hline
\end{tabular}




\begin{tabular}{|c|c|c|c|c|c|c|c|c|}
\hline \multirow{2}{*}{ Horizon } & \multirow{2}{*}{ Depth } & \multicolumn{7}{|c|}{ Total Elemental Analysis } \\
\hline & & $\mathrm{Fe}$ & $\mathrm{Mn}$ & $\mathrm{Al}$ & $\mathrm{Ca}$ & $\mathrm{Mg}$ & $\mathrm{Na}$ & $\mathrm{K}$ \\
\hline & $\mathrm{cm}$ & & & & $-\mathrm{mg} \mathrm{kg}^{-1}$ & & & \\
\hline A & $0-7$ & 25459.9 & 1091.6 & 51516.8 & 4355.6 & 3978.7 & 1463.5 & 1337.4 \\
\hline Ap & $7-21$ & 28499.4 & 1188.7 & 54837.8 & 3568.7 & 2905.2 & 1533.4 & 1303.6 \\
\hline Btss1 & $21-60$ & 35991.6 & 712.5 & 78619.5 & 4626.8 & 5804.8 & 1151.2 & 1532.6 \\
\hline Btss2 & $60-72$ & 38390.5 & 157.9 & 86649.5 & 22735.6 & 6780.5 & 690.3 & 1552.0 \\
\hline
\end{tabular}

\begin{tabular}{|c|c|c|c|c|c|c|c|c|}
\hline \multirow{2}{*}{ Horizon } & \multirow{2}{*}{ Depth } & \multicolumn{7}{|c|}{ Total Elemental Analysis } \\
\hline & & $P$ & $\mathrm{Si}$ & $\mathrm{Cu}$ & $\mathrm{Zn}$ & $\mathrm{Ni}$ & As & $\mathrm{Co}$ \\
\hline & $\mathrm{cm}$ & & & & $\mathrm{mg} \mathrm{kg}^{-1}$ & & & \\
\hline A & $0-7$ & 646.8 & \begin{tabular}{|l|}
140169.9 \\
\end{tabular} & 44.6 & 102.4 & 13.4 & 4.3 & 108.2 \\
\hline$A p$ & $7-21$ & 347.0 & 141419.4 & 45.1 & 103.7 & 14.0 & 2.5 & 109.9 \\
\hline Btss1 & $21-60$ & 190.6 & 122718.5 & 62.7 & 121.7 & 28.9 & 3.3 & 148.0 \\
\hline Btss2 & $60-72$ & 278.6 & 116750.2 & 72.0 & 126.8 & 30.8 & 4.8 & 172.0 \\
\hline
\end{tabular}

\begin{tabular}{|c|c|c|c|c|c|c|c|c|c|c|c|}
\hline \multirow{2}{*}{ Horizon } & \multirow{2}{*}{ Depth } & \multicolumn{10}{|c|}{ Total Elemental Analysis } \\
\hline & & $\mathrm{Se}$ & $\mathrm{Cd}$ & $\mathrm{Pb}$ & $\mathrm{Ba}$ & $\mathrm{Ag}$ & $\mathrm{Hg}$ & Mo & $\mathrm{Cr}$ & $\mathrm{Be}$ & $\mathrm{V}$ \\
\hline & $\mathrm{cm}$ & & & & & ----m & & & & & \\
\hline$A$ & $0-7$ & BDL & BDL & 60.5 & 487.5 & $\overline{B D L}$ & BDL & BDL & 14.3 & 3.1 & 62.7 \\
\hline Ap & $7-21$ & 4.2 & $\mathrm{BDL}$ & 18.1 & 487.8 & $\mathrm{BDL}$ & $\mathrm{BDL}$ & BDL & 17.8 & 3.3 & 65.5 \\
\hline Btss1 & $21-60$ & 0.3 & $\mathrm{BDL}$ & 21.6 & 535.9 & $\mathrm{BDL}$ & $\mathrm{BDL}$ & BDL & 41.9 & 5.5 & 94.8 \\
\hline Btss2 & $60-72$ & 0.2 & $\mathrm{BDL}$ & 20.0 & 691.7 & BDL & BDL & BDL & 51.9 & 5.6 & 105.7 \\
\hline
\end{tabular}

\begin{tabular}{|c|c|c|c|c|c|}
\hline Horizon & Depth & \multicolumn{4}{|c|}{ Clay Mineralogy } \\
\hline & $\mathrm{cm}$ & & & peak size- & \\
\hline Btss1 & $21-60$ & Mica - 2 & Kaolinite - 2 Vermiculite - 1 & Montmorillonite-Mica - 1 & Quartz - 1 Geothite - 1 \\
\hline \multicolumn{2}{|r|}{ ak Size: } & 5 - Very Large $(>50 \%)$ & $\operatorname{rrge}(>50 \%)$ & 4 - Large $(30-50 \%)$ & 3 - Medium (10-30\%) \\
\hline
\end{tabular}




\section{A.6. Carbo \#3 Site and Profile Description}

Sampled as: Carbo

Lab \#: S99-WV003-007 -- Carbo \#3

Location: Abandoned field east of Inwood quarry on D.L. Morgan property - Berkeley

County

Latitude: $39^{\circ} 20^{\prime} 18^{\prime \prime} \mathrm{N}$; Longitude: $78^{\circ} 02^{\prime} 11^{\prime \prime} \mathrm{W}$

Physiography: Valley and Ridge Province

Elevation: $167.2 \mathrm{~m} \pm 11.9 \mathrm{~m}(550 \mathrm{ft} . \pm 39 \mathrm{ft}$.

Land use and vegetation: Abandoned field with red bud, cedar, grasses and forbs.

Parent Material: Residual - Chambersburg Limestone

Described by: James Bell, John Sencindiver, Brian Cooley, Bill Bates and Jason Knopp

on July 9, 1999

Ap - 0 to $9 \mathrm{~cm}$ (0 to 3.5 inches); dark brown (10YR 3/3) silty clay loam; moderate medium granular structure; friable; slightly sticky and slightly plastic; many very fine to medium roots; 8 percent limestone channers; clear smooth boundary.

$\mathrm{Bt}-9$ to $28 \mathrm{~cm}$ (3.5 to 11 inches); brown (7.5YR 4/4) clay; weak coarse prismatic structure parting to moderate medium and coarse subangular blocky; firm; very sticky and very plastic; very few medium and common very fine and fine roots; many continuous distinct clay films on ped faces; 5 percent limestone channers; gradual wavy boundary.

Btss - 28 to $46 \mathrm{~cm}$ (11 to 18 inches); strong brown (7.5YR 4/6) silty clay; moderate fine and medium subangular blocky structure; firm; very sticky and very plastic; few very fine and fine roots; many continuous distinct clay films on ped faces; common continuous prominent slickensides 2 to $20 \mathrm{~cm}$; 5 percent limestone channers; clear wavy boundary.

B't -46 to $58 \mathrm{~cm}$ (18 to 23 inches); 75 percent brown (7.5YR 4/4) and 25 percent strong brown (7.5YR 4/6) silty clay; moderate fine and medium subangular blocky structure; firm; very sticky and very plastic; very few very fine and fine roots; many continuous distinct clay films on ped faces; 5 percent limestone channers; abrupt irregular boundary.

$\mathrm{R}-58+\mathrm{cm}(23+$ inches $)-$ limestone bedrock 


\section{A.7. Carbo \#3 Characterization Data}

\begin{tabular}{|c|c|c|c|c|c|c|c|c|c|}
\hline \multirow{3}{*}{ Horizon } & \multirow{3}{*}{ Depth } & \multicolumn{8}{|c|}{ Particle Size } \\
\hline & & \multicolumn{3}{|c|}{ Total } & \multicolumn{5}{|c|}{ Sand } \\
\hline & & Sand & Silt & Clay & V. Coarse & Coarse & Medium & Fine & V. Fine \\
\hline & $\mathrm{cm}$ & & & & $\%$ & & & & 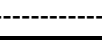 \\
\hline Ap & $0-9$ & 6.3 & 40.6 & 53.1 & 0.9 & 1.0 & 0.8 & 1.2 & 2.4 \\
\hline $\mathrm{Bt}$ & $9-28$ & 4.1 & 38.4 & 57.5 & 0.4 & 0.5 & 0.6 & 0.8 & 1.8 \\
\hline Btss & $28-46$ & 3.7 & 39.7 & 56.6 & 0.3 & 0.4 & 0.5 & 0.7 & 1.8 \\
\hline B't & $46-58$ & 3.9 & 41.7 & 54.4 & 0.2 & 0.4 & 0.6 & 0.8 & 1.9 \\
\hline
\end{tabular}

\begin{tabular}{|c|c|c|c|c|c|c|c|}
\hline \multirow{3}{*}{ Horizon } & \multirow{3}{*}{ Depth } & \multicolumn{4}{|c|}{ Bulk Density } & \multirow{2}{*}{\multicolumn{2}{|c|}{ Atterberg Limits }} \\
\hline & & \multicolumn{2}{|c|}{ Oven-Dry } & \multicolumn{2}{|c|}{33 kPA Desorption } & & \\
\hline & & $\mathrm{Db}>2 \mathrm{~mm}$ & $\mathrm{Db}<2 \mathrm{~mm}$ & $\mathrm{Db}>2 \mathrm{~mm}$ & $\mathrm{Db}<2 \mathrm{~mm}$ & Liquid Limit & Plasticity Index \\
\hline & $\mathrm{cm}$ & - & --------g & $n^{-3}-$ & 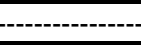 & & \\
\hline $\mathrm{Ap}$ & $0-9$ & 1.64 & 1.58 & 1.44 & 1.38 & 59 & 35 \\
\hline $\mathrm{Bt}$ & $9-28$ & 1.82 & 1.82 & 1.64 & 1.63 & 52 & 34 \\
\hline Btss & $28-46$ & 1.86 & 1.85 & 1.68 & 1.66 & 61 & 42 \\
\hline$B^{\prime} t$ & $46-58$ & 1.78 & 1.78 & 1.62 & 1.61 & 60 & 41 \\
\hline
\end{tabular}

\begin{tabular}{|c|c|c|c|c|c|c|}
\hline \multirow{2}{*}{ Horizon } & \multirow{2}{*}{ Depth } & \multirow{2}{*}{$\begin{array}{c}\text { Rock } \\
\text { Fragments by } \\
\text { Wt. }\end{array}$} & \multicolumn{3}{|c|}{ Water Retention } & \multirow{2}{*}{ COLE } \\
\hline & & & $33 \mathrm{kPA}$ & $1500 \mathrm{kPA}$ & WRD & \\
\hline & $\mathrm{cm}$ & 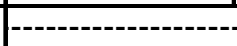 & $---0 \%----$ & 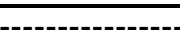 & $\mathrm{cm} \mathrm{cm}^{-1}$ & \\
\hline$A p$ & $0-9$ & 2.0 & 30.7 & 17.2 & 0.17 & 0.05 \\
\hline $\mathrm{Bt}$ & $9-28$ & 0.7 & 30.9 & 18.5 & 0.19 & 0.04 \\
\hline Btss & $28-46$ & 0.5 & 34.4 & 18.9 & 0.24 & 0.04 \\
\hline$B^{\prime} t$ & $46-58$ & 0.8 & 34.4 & 18.3 & 0.25 & 0.04 \\
\hline
\end{tabular}

\begin{tabular}{|c|c|c|c|c|c|c|c|c|c|c|c|c|}
\hline \multirow{2}{*}{ Horizon } & \multirow{2}{*}{ Depth } & \multicolumn{6}{|c|}{ Extractable } & \multicolumn{2}{|c|}{ CEC } & \multirow{2}{*}{ ECEC } & \multicolumn{2}{|c|}{ Base Saturation } \\
\hline & & $\mathrm{Ca}$ & $\mathrm{Mg}$ & $\mathrm{Na}$ & $\mathrm{K}$ & Acidity & $\mathrm{Al}$ & CEC-8.2 & CEC-7 & & CEC-8.2 & CEC-7 \\
\hline & $\mathrm{cm}$ & & & & & $-\mathrm{cmol}_{\mathrm{c}} \mathrm{K}$ & & & & & -- & -- \\
\hline Ap & $0-9$ & 22.1 & 0.9 & 0.1 & 0.5 & 4.4 & -- & 28.0 & 26.4 & -- & 84.3 & 89.4 \\
\hline $\mathrm{Bt}$ & $9-28$ & 19.1 & 0.5 & 0.1 & 0.4 & 5.1 & -- & 25.2 & 23.1 & -- & 79.8 & 87.0 \\
\hline Btss & $28-46$ & 18.8 & 0.3 & 0.1 & 0.4 & 5.7 & -- & 25.3 & 22.7 & -- & 77.5 & 86.3 \\
\hline$B^{\prime} t$ & $46-58$ & 18.3 & 0.4 & 0.1 & 0.4 & 6.9 & -- & 26.1 & 22.7 & -- & 73.6 & 84.6 \\
\hline
\end{tabular}

\begin{tabular}{|c|c|c|c|c|c|c|c|c|}
\hline \multirow{2}{*}{ Horizon } & \multirow{2}{*}{ Depth } & \multirow{2}{*}{ Al Saturation } & \multicolumn{3}{|c|}{ Total } & \multirow{2}{*}{$\begin{array}{c}\text { Extractable } \\
\mathrm{Mn}\end{array}$} & \multicolumn{2}{|c|}{$\mathrm{pH}$} \\
\hline & & & Carbon & Sulfur & Nitrogen & & 1:1 Water & $1: 2 \mathrm{CaCl}_{2}$ \\
\hline & $\mathrm{cm}$ & - & ------\% & 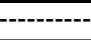 & - & $\mathrm{mg} \mathrm{kg}^{-1}$ & & \\
\hline Ap & $0-9$ & -- & 2.65 & 0.03 & 0.12 & -- & 7.0 & 6.5 \\
\hline $\mathrm{Bt}$ & $9-28$ & -- & 0.72 & 0.01 & 0.01 & -- & 7.1 & 6.4 \\
\hline Btss & $28-46$ & -- & 0.43 & 0.01 & $\overline{B D L}$ & -- & 7.2 & 6.4 \\
\hline $\mathrm{B}^{\prime} \mathrm{t}$ & $46-58$ & -- & 0.40 & BDL & 0.01 & $\overline{--}$ & 7.0 & 6.1 \\
\hline
\end{tabular}




\begin{tabular}{|c|c|c|c|c|c|c|c|c|}
\hline \multirow{2}{*}{ Horizon } & \multirow{2}{*}{ Depth } & \multicolumn{7}{|c|}{ Total Elemental Analysis } \\
\hline & & $\mathrm{Fe}$ & $\mathrm{Mn}$ & $\mathrm{Al}$ & $\mathrm{Ca}$ & $\mathrm{Mg}$ & $\mathrm{Na}$ & $\mathrm{K}$ \\
\hline & $\mathrm{cm}$ & & & & $-\mathrm{mg} \mathrm{kg}^{-1}$ & & & \\
\hline Ap & $0-9$ & 36311.8 & 778.4 & 61930.0 & 4876.8 & 4893.7 & 1520.5 & 1513.6 \\
\hline $\mathrm{Bt}$ & $9-28$ & 39314.4 & 456.0 & 73969.1 & 4018.6 & 3639.0 & 1615.8 & 1673.0 \\
\hline Btss & $28-46$ & 37863.2 & 534.0 & 65599.0 & 4124.5 & 5455.6 & 1984.8 & 1671.7 \\
\hline $\bar{B}$ 't & $46-58$ & 40069.2 & 669.6 & 72368.1 & 4281.2 & 6210.6 & 2448.9 & 1739.0 \\
\hline
\end{tabular}

\begin{tabular}{|c|c|c|c|c|c|c|c|c|}
\hline \multirow{2}{*}{ Horizon } & \multirow{2}{*}{ Depth } & \multicolumn{7}{|c|}{ Total Elemental Analysis } \\
\hline & & $P$ & $\mathrm{Si}$ & $\mathrm{Cu}$ & $\mathrm{Zn}$ & $\mathrm{Ni}$ & As & Co \\
\hline & $\mathrm{cm}$ & & & & $\mathrm{mg} \mathrm{kg}^{-1}$ & & & \\
\hline Ap & $0-9$ & 444.8 & 130689.5 & 64.6 & 327.3 & 23.4 & 5.8 & 158.7 \\
\hline $\mathrm{Bt}$ & $9-28$ & 201.2 & 130924.2 & 69.2 & 232.3 & 28.1 & 4.6 & 151.4 \\
\hline Btss & $28-46$ & 230.9 & 131811.6 & 67.5 & 179.4 & 21.4 & 4.1 & 160.5 \\
\hline $\mathrm{B}^{\prime} \mathrm{t}$ & $46-58$ & 229.6 & 134507.5 & 69.9 & 243.3 & 28.6 & 4.6 & 149.1 \\
\hline
\end{tabular}

\begin{tabular}{|c|c|c|c|c|c|c|c|c|c|c|c|}
\hline \multirow{2}{*}{ Horizon } & \multirow{2}{*}{ Depth } & \multicolumn{10}{|c|}{ Total Elemental Analysis } \\
\hline & & $\mathrm{Se}$ & $\mathrm{Cd}$ & $\mathrm{Pb}$ & $\mathrm{Ba}$ & $\mathrm{Ag}$ & $\mathrm{Hg}$ & Mo & $\mathrm{Cr}$ & $\mathrm{Be}$ & $\mathrm{V}$ \\
\hline & $\mathrm{cm}$ & & & & & ----m & & & & & \\
\hline$\overline{A p}$ & $0-9$ & 0.9 & BDL & 32.6 & 647.9 & $\overline{B D L}$ & BDL & BDL & 32.4 & 4.9 & 90.7 \\
\hline $\mathrm{Bt}$ & $9-28$ & 0.2 & $\mathrm{BDL}$ & 23.2 & 633.0 & $\mathrm{BDL}$ & $\mathrm{BDL}$ & BDL & 41.7 & 5.5 & 114.9 \\
\hline Btss & $28-46$ & 0.3 & $\mathrm{BDL}$ & 22.0 & 583.5 & $\mathrm{BDL}$ & $\overline{\mathrm{BDL}}$ & $\mathrm{BDL}$ & 45.3 & 5.8 & 116.8 \\
\hline B't & $46-58$ & 0.2 & 0.3 & 24.0 & 634.7 & BDL & BDL & BDL & 46.1 & 5.6 & 116.4 \\
\hline
\end{tabular}

\begin{tabular}{|c|c|c|c|c|c|c|}
\hline Horizon & Depth & \multicolumn{5}{|c|}{ Clay Mineralogy } \\
\hline & $\mathrm{cm}$ & & & eak size- & & \\
\hline $\mathrm{Bt}$ & $9-28$ & Mica - 2 & Kaolinite - 2 Vermiculite - 2 & Montmorillonite - Mica - 1 & Quartz - 1 & Geothite - 1 \\
\hline Btss & $28-46$ & Mica - 2 & Kaolinite - 2 Vermiculite - 2 & Quartz - 1 & $e-1$ & \\
\hline
\end{tabular}

Relative Peak Size: 5 - Very Large (>50\%) 4 - Large (30-50\%) 3 - Medium (10-30\%)

$$
2 \text { - Small }(3-10 \%) \quad 1 \text { - Very Small }(<3 \%)
$$




\section{Appendix B}

B.1. Swanpond Official Series Description

B.2. Swanpond \#1 Site and Profile Description

B.3. Swanpond \#1 Characterization Data

B.4. Swanpond \#2 Site and Profile Description

B.5. Swanpond \#2 Characterization Data

B.6. Swanpond \#3 Site and Profile Description

B.7. Swanpond \#3 Characterization Data

B.8. Swanpond \#4 Site and Profile Description

B.9. Swanpond \#4 Characterization Data 


\section{B.1. Swanpond Official Series Description}

LOCATION SWANPOND

$W V+M D$

Established Series

LHC-JWB-REP

$01 / 2000$

\section{SWANPOND SERIES}

The Swanpond series consists of very deep, moderately well drained, slowly permeable soils. They formed in residuum weathered from limestone bedrock on nearly level to gently sloping uplands. Slopes range from 0 to 8 percent. Mean annual precipitation is about 38 inches and the mean annual temperature is about 53 degrees $\mathrm{F}$.

TAXONOMIC CLASS: Very-fine, mixed, active, mesic Vertic Paleudalfs

TYPICAL PEDON: Swanpond silt loam, 0 to 3 percent slopes in a corn field. (Colors are for moist soil.)

Ap--0 to 7 inches; brown (10YR 4/3) silt loam; moderate fine and medium granular structure; friable; few very fine roots throughout; neutral; abrupt smooth boundary. (6 to 12 inches thick)

Bt1--7 to 25 inches; yellowish brown (10YR 5/6) clay; weak coarse prismatic parting to moderate fine and medium subangular blocky structure; friable; very sticky, very plastic; very few, very fine roots throughout; common

distinct clay films on faces of peds; strongly acid; clear wavy boundary.

Bt2--25 to 32 inches; yellowish brown (10YR 5/6) clay; weak coarse prismatic parting to moderate fine and medium subangular blocky structure; friable; very sticky, very plastic; very few very fine roots throughout; common

distinct clay films on faces of peds; few prominent black manganese stains on faces of peds; strongly acid; clear wavy boundary.

Btss1--32 to 39 inches; yellowish brown (10YR 5/6) clay; moderate coarse prismatic parting to moderate fine and medium angular blocky structure; friable; very sticky, very plastic; very few, very fine roots between peds; many prominent clay films on faces of peds; few fine prominent gray (10YR 6/1) redox depletions along faces of peds; common prominent black manganese stains on faces of peds; common slickensides; strongly acid; clear wavy boundary.

Btss2--39 to 49 inches; yellowish brown (10YR 5/6) clay; moderate coarse prismatic parting to moderate fine and medium angular blocky structure; firm; very sticky, very plastic; very few, very fine roots between peds; many prominent clay films on faces of peds; common coarse prominent gray (10YR 6/1) redox depletions along faces of peds; 
common prominent black manganese stains on faces of peds; common slickensides; strongly acid; clear wavy boundary.

Btss3--49 to 65 inches; strong brown (7.5YR 5/6) clay; strong coarse prismatic parting to moderate fine and medium angular blocky structure; firm; very sticky, very plastic; many prominent clay films on faces of peds; many coarse prominent gray (10YR 6/1) redox depletions along faces of peds; common slickensides; strongly acid. (Combined thickness of the Bt horizon is 45 to 60 inches or more.)

TYPE LOCATION: Berkeley County, West Virginia; located about 1300 feet North 21 degrees West of the intersection of county routes 5/9 and 5/3 in the Greensburg area. USGS Martinsburg topographic quadrangle; latitude 39 degrees 28 minutes 24 seconds $\mathrm{N}$; longitude 77 degrees 53 minutes 23 seconds W.

RANGE IN CHARACTERISTICS: Solum thickness and depth to bedrock are more than 60 inches. Content of coarse fragments, commonly chert or limestone, ranges from 0 to 20 percent throughout. Reaction ranges from strongly acid to slightly alkaline, unless the soil has been limed. Depth to redoximorphic features ranges from 30 to 40 inches.

The Ap horizon has hue of 10YR, value 3 or 4, and chroma of 3 through 5. It is silt loam or silty clay loam.

Some pedons have a thin BA horizon with hue of $10 \mathrm{YR}$, value of 4 , and chroma of 3 through 6. It is silt loam or silty clay loam.

The Bt horizon has hue of 10YR, 7.5YR or 5YR value of 4 through 6 , and chroma 4 through 8 . Few to many redoximorphic features are present below a depth of 30 inches. It is typically clay, but some pedons have thin subhorizons of silty clay in the upper part.

The $\mathrm{BC}$ and $\mathrm{C}$ horizons, where present, have hue of $7.5 \mathrm{YR}$ or $5 \mathrm{YR}$, value of 4 or 5 , and chroma 4 through 8 , with few through many redoximorphic features. It is clay or silty clay.

COMPETING SERIES: There are no known other series in this family. The Gepp,

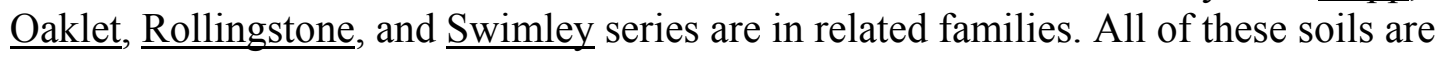
well drained, and do not have low chroma redoximorphic features within 40 inches.

GEOGRAPHIC SETTING: Swanpond soils are on nearly level to gently sloping, slightly convex to slightly concave, broad, topographically low upland areas. Slopes range from 0 to 8 percent. These soils are formed in residuum weathered from limestone bedrock of Ordovician and Cambrian Age. Climate is humid temperate. Mean annual precipitation ranges from 33 to 42 inches, and the mean annual temperature ranges from 48 to 54 degrees $\mathrm{F}$. The number of frost free days ranges from 155 to 180 . 
GEOGRAPHICALLY ASSOCIATED SOILS: These are the well drained Carbo, Endcav, Hagerstown and Opequon soils on higher adjacent upland slopes; and the Tentative, moderately well drained, fine-loamy, Funkstown soils along lower concave upland drainageways and headslopes.

DRAINAGE AND PERMEABILITY: Moderately well drained. Runoff is slow to medium. Permeability is slow.

USE AND VEGETATION: Most areas are used for cultivated crops, pasture and hay. Some areas are used for urban development. A small acreage is in woodland of mixed hardwoods.

DISTRIBUTION AND EXTENT: The Great Valley of West Virginia, Maryland and Pennsylvania and possibly Virginia. The acreage is small.

MLRA OFFICE RESPONSIBLE: Morgantown, West Virginia

SERIES ESTABLISHED: Berkeley County, West Virginia, 1995.

\section{REMARKS:}

1. These soils were formerly mapped as members of the Pickaway or Carbo soil series.

2. Diagnostic horizons and features in this pedon are:

a. Ochric epipedon--the zone from 0 to 7 inches.

b. Argillic horizon--the zone from 7 to 65 inches.

c. Common slickensides starting at 32 inches

SIR $=$ WV0136

MLRA $=147$

National Cooperative Soil Survey

U.S.A. 


\section{B.2. Swanpond \#1 Site and Profile Description}

Sampled as: Swanpond

Lab \#: S99- WV-003-002 -- Swanpond \#1

Location: Chandler Farm 0.5 miles northeast of Ridgeway - Berkeley County

Latitude: $39^{\circ} 18^{\prime} 02^{\prime \prime} \mathrm{N}$; Longitude: $78^{\circ} 03^{\prime} 42^{\prime \prime} \mathrm{W}$

Physiography: Valley and Ridge Province

Elevation: $177.8 \mathrm{~m} \pm 9.4 \mathrm{~m}(585 \mathrm{ft} . \pm 31 \mathrm{ft}$. $)$

Land Use and Vegetation: Plowed abandoned agricultural field with weeds.

Parent Material: Residual - Beekmantown Limestone

Described by: John Sencindiver and Brian Cooley on June 3, 1999

Ap1 - 0 to $10 \mathrm{~cm}$ (0 to 4 inches); very dark grayish brown (10YR 3/2) silt loam; weak medium granular structure; friable; non-sticky and non-plastic; common very fine to medium roots; 1 percent rock fragments; abrupt wavy boundary.

Ap2 - 10 to $32 \mathrm{~cm}$ (4 to 12.5 inches); dark grayish brown (10YR 4/2) with pockets of yellowish brown (10YR 5/6) silt loam; weak medium subangular blocky structure parting to weak fine and medium granular; friable; non-sticky and non-plastic; few very fine to medium roots; few charcoal fragments; 2 percent rock fragments; abrupt wavy boundary.

Bt1 - 32 to $53 \mathrm{~cm}$ (12.5 to 21 inches); yellowish brown (10YR 5/6) with pockets of dark grayish brown $(2.5 \mathrm{Y} 4 / 2)$ silty clay loam; moderate medium subangular blocky structure; friable; slightly sticky and slightly plastic; few very fine and fine roots; few discontinuous faint strong brown (7.5YR 5/6) clay films; 2 percent rock fragments; clear wavy boundary.

Bt2 - 53 to $75 \mathrm{~cm}$ (21 to 29.5 inches); yellowish brown (10YR 5/6) silty clay loam; moderate medium subangular blocky structure; friable; sticky and plastic; few very fine and fine roots; dark grayish brown $(2.5 \mathrm{Y} 4 / 2)$ coatings in root channels; common discontinuous faint clay films; 2 percent rock fragments; clear wavy boundary.

Btss 1 - 75 to $122 \mathrm{~cm}$ (29.5 to 48 inches); strong brown (7.5YR 5/8) clay; moderate fine and medium subangular blocky structure; very plastic and very sticky; few very fine roots; few fine yellowish red (5YR 5/6) concentrations; few medium black (N 2.5/0) coatings and concentrations; many continuous prominent clay films; few slickensides 1 to $5 \mathrm{~cm}$; less than 1 percent rock fragments; clear irregular boundary.

Btss $2-122$ to $165+\mathrm{cm}$ (48 to $65+$ inches); light olive brown (2.5Y 5/6) clay; weak fine and medium subangular blocky structure; very plastic and very sticky; common coarse dark yellowish brown (10YR 3/4) masses; common medium light brownish gray (10YR 6/2) depletions; common medium black (N 2.5/0) coatings and concentrations; many continuous distinct clay films; few slickensides 1 to $5 \mathrm{~cm}$; less than 1 percent rock fragments. 
Note: Several large slickensides up to $10 \mathrm{~cm}$ x $20 \mathrm{~cm}$ were found when sampling the Btss1. Several large slickensides up to $15 \mathrm{~cm}$ x $30 \mathrm{~cm}$ were found when sampling the Btss2. 


\section{B.3. Swanpond \#1 Characterization Data}

\begin{tabular}{|c|c|c|c|c|c|c|c|c|c|}
\hline \multirow{3}{*}{ Horizon } & \multirow{3}{*}{ Depth } & \multicolumn{8}{|c|}{ Particle Size } \\
\hline & & \multicolumn{3}{|c|}{ Total } & \multicolumn{5}{|c|}{ Sand } \\
\hline & & Sand & Silt & Clay & V. Coarse & Coarse & Medium & Fine & V. Fine \\
\hline & $\mathrm{cm}$ & & & & $----\%$ & & & & \\
\hline Ap1 & $0-10$ & 15.5 & 62.9 & 21.6 & 2.7 & 2.9 & 3.3 & 2.6 & 4.0 \\
\hline Ap2 & $10-32$ & 14.2 & 64.8 & 21.0 & 1.9 & 3.2 & 3.2 & 2.6 & 3.3 \\
\hline Bt1 & $32-53$ & 14.3 & 59.6 & 26.1 & 1.2 & 3.1 & 3.4 & 3.0 & 3.6 \\
\hline Bt2 & $53-75$ & 12.6 & 40.8 & 46.6 & 2.1 & 2.3 & 2.9 & 2.6 & 2.7 \\
\hline Btss1 & $75-122$ & 3.7 & 21.4 & 74.9 & 0.3 & 0.5 & 0.7 & 0.8 & 1.4 \\
\hline Btss2 & $122-165$ & 7.0 & 13.6 & 79.4 & 0.9 & 1.5 & 1.4 & 1.5 & 1.7 \\
\hline
\end{tabular}

\begin{tabular}{|c|c|c|c|c|c|c|c|}
\hline \multirow{3}{*}{ Horizon } & \multirow{3}{*}{ Depth } & \multicolumn{4}{|c|}{ Bulk Density } & \multirow{2}{*}{\multicolumn{2}{|c|}{ Atterberg Limits }} \\
\hline & & \multicolumn{2}{|c|}{ Oven-Dry } & \multicolumn{2}{|c|}{33 kPA Desorption } & & \\
\hline & & $\mathrm{Db}>2 \mathrm{~mm}$ & $\mathrm{Db}<2 \mathrm{~mm}$ & $\mathrm{Db}>2 \mathrm{~mm}$ & $\mathrm{Db}<2 \mathrm{~mm}$ & Liquid Limit & Plasticity Index \\
\hline & $\mathrm{cm}$ & & $--g$ & $m^{3}$ & & & \\
\hline Ap1 & $0-10$ & 1.64 & 1.60 & 1.61 & 1.58 & 33 & 14 \\
\hline Ap2 & $10-32$ & 1.61 & 1.57 & 1.59 & 1.54 & 31 & 13 \\
\hline Bt1 & $32-53$ & 1.77 & 1.74 & 1.73 & 1.70 & 27 & 13 \\
\hline Bt2 & $53-75$ & 1.78 & 1.71 & 1.68 & 1.61 & 41 & 26 \\
\hline Btss1 & $75-122$ & 1.72 & 1.68 & 1.52 & 1.48 & 67 & 45 \\
\hline Btss2 & $122-165$ & 1.66 & 1.64 & 1.32 & 1.30 & 77 & 53 \\
\hline
\end{tabular}

\begin{tabular}{|c|c|c|c|c|c|c|}
\hline \multirow{2}{*}{ Horizon } & \multirow{2}{*}{ Depth } & \multirow{2}{*}{$\begin{array}{c}\text { Rock } \\
\text { Fragments by } \\
\text { Wt. }\end{array}$} & \multicolumn{3}{|c|}{ Water Retention } & \multirow{2}{*}{ COLE } \\
\hline & & & $33 \mathrm{kPA}$ & $1500 \mathrm{kPA}$ & \multirow{2}{*}{$\frac{\text { WRD }}{\mathrm{cm} \mathrm{cm}^{-1}}$} & \\
\hline & $\mathrm{cm}$ & & ---\%-- & - & & \\
\hline Ap1 & $0-10$ & 7.4 & 28.8 & 8.4 & 0.32 & 0.01 \\
\hline Ap2 & $10-32$ & 6.3 & 29.0 & 7.8 & 0.32 & 0.01 \\
\hline Bt1 & $32-53$ & 7.1 & 27.1 & 8.4 & 0.31 & 0.01 \\
\hline Bt2 & $53-75$ & 8.0 & 28.6 & 17.0 & 0.18 & 0.02 \\
\hline Btss1 & $75-122$ & 0.7 & 42.9 & 28.4 & 0.21 & 0.06 \\
\hline Btss2 & $122-165$ & 3.8 & 48.3 & 31.3 & 0.22 & 0.09 \\
\hline
\end{tabular}

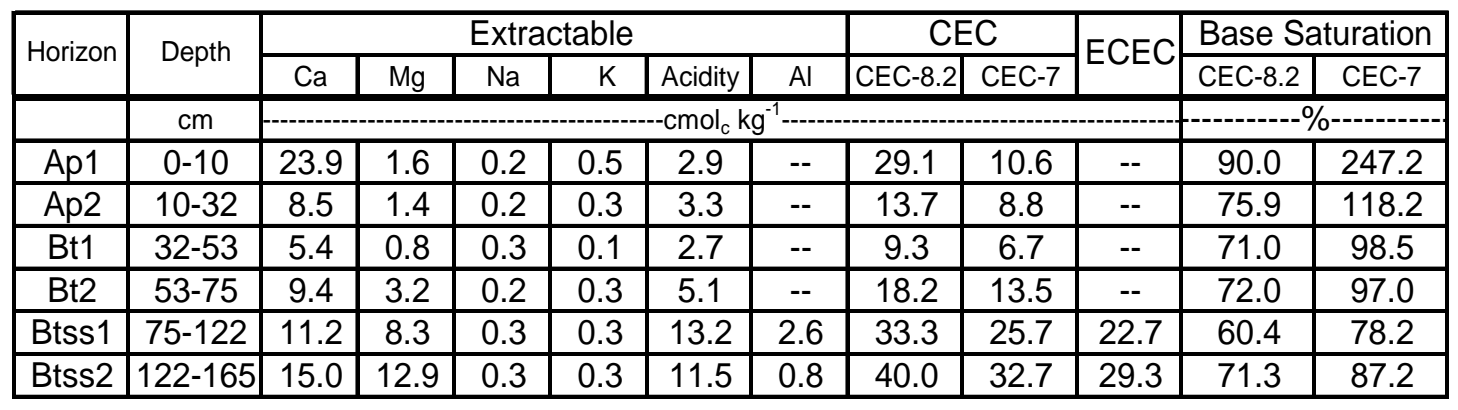




\begin{tabular}{|c|c|c|c|c|c|c|c|c|}
\hline \multirow{2}{*}{ Horizon } & \multirow{2}{*}{ Depth } & \multirow{2}{*}{ Al Saturation } & \multicolumn{3}{|c|}{ Total } & \multirow{2}{*}{$\begin{array}{c}\text { Extractable } \\
\text { Mn }\end{array}$} & \multicolumn{2}{|c|}{$\mathrm{pH}$} \\
\hline & & & Carbon & Sulfur & Nitrogen & & 1:1 Water & $1: 2 \mathrm{CaCl}_{2}$ \\
\hline & $\mathrm{cm}$ & & $\%$ & & & $\mathrm{mg} \mathrm{kg}^{-1}$ & & \\
\hline Ap1 & $0-10$ & -- & 2.10 & 0.02 & 0.17 & -- & 6.0 & 6.0 \\
\hline Ap2 & $10-32$ & -- & 1.34 & 0.02 & 0.11 & -- & 6.6 & 6.2 \\
\hline Bt1 & $32-53$ & -- & 0.27 & 0.01 & 0.03 & -- & 6.9 & 6.3 \\
\hline Bt2 & $53-75$ & -- & 0.26 & 0.01 & 0.04 & -- & 6.8 & 6.2 \\
\hline Btss1 & $75-122$ & 11.5 & 0.21 & 0.03 & 0.07 & 0.2 & 6.0 & 4.6 \\
\hline Btss2 & $122-165$ & 2.7 & 0.18 & 0.01 & 0.07 & 5.6 & 5.5 & 4.8 \\
\hline
\end{tabular}

\begin{tabular}{|c|c|c|c|c|c|c|c|c|}
\hline \multirow{2}{*}{ Horizon } & \multirow{2}{*}{ Depth } & \multicolumn{7}{|c|}{ Total Elemental Analysis } \\
\hline & & $\mathrm{Fe}$ & $\mathrm{Mn}$ & $\mathrm{Al}$ & $\mathrm{Ca}$ & $\mathrm{Mg}$ & $\mathrm{Na}$ & $\mathrm{K}$ \\
\hline & $\mathrm{cm}$ & & & & $-\mathrm{mg} \mathrm{kg}^{-1}$ & & & \\
\hline Ap1 & $0-10$ & 18826.7 & 1125.5 & 17220.1 & 3531.1 & 788.0 & 1238.8 & 961.4 \\
\hline Ap2 & $10-32$ & 20610.4 & 1361.2 & 18467.8 & 1708.1 & 743.3 & 1342.3 & 925.7 \\
\hline Bt1 & $32-53$ & 22807.4 & 525.1 & 28394.7 & 1529.8 & 1525.2 & 1032.2 & 893.8 \\
\hline Bt2 & $53-75$ & 34746.5 & 274.6 & 50662.4 & 1894.6 & 3095.6 & 627.7 & 838.9 \\
\hline Btss1 & $75-122$ & 441998.1 & 44.5 & 86390.1 & 2264.1 & 5471.2 & 456.7 & 983.0 \\
\hline Btss2 & $122-165$ & 58541.7 & 1894.5 & 92311.5 & 2829.8 & 6461.8 & 471.3 & 1323.5 \\
\hline
\end{tabular}

\begin{tabular}{|c|c|c|c|c|c|c|c|c|}
\hline \multirow{2}{*}{ Horizon } & \multirow{2}{*}{ Depth } & \multicolumn{7}{|c|}{ Total Elemental Analysis } \\
\hline & & $P$ & $\mathrm{Si}$ & $\mathrm{Cu}$ & $\overline{Z n}$ & $\mathrm{Ni}$ & As & Co \\
\hline & $\mathrm{cm}$ & & & & $\mathrm{ng} \mathrm{kg}^{-1}$ & & & \\
\hline Ap1 & $0-10$ & 491.7 & 124857.5 & 51.7 & 137.2 & 5.1 & 11.5 & 106.0 \\
\hline Ap2 & $10-32$ & 390.8 & 138525.5 & 39.5 & 106.1 & 3.6 & 10.8 & 108.3 \\
\hline Bt1 & $32-53$ & 167.9 & 121161.8 & 40.6 & 65.4 & 4.1 & 9.5 & 121.9 \\
\hline $\mathrm{Bt} 2$ & $53-75$ & 115.5 & 112698.2 & 59.6 & 134.9 & 8.0 & 11.2 & 169.3 \\
\hline Btss1 & $75-122$ & 101.4 & 120611.7 & 54.8 & 172.6 & 21.1 & 8.5 & 189.1 \\
\hline Btss2 & $122-165$ & 86.1 & 112005.1 & 85.2 & 181.7 & 34.8 & 12.3 & 278.1 \\
\hline
\end{tabular}

\begin{tabular}{|c|c|c|c|c|c|c|c|c|c|c|c|}
\hline \multirow{2}{*}{ Horizon } & \multirow{2}{*}{ Depth } & \multicolumn{10}{|c|}{ Total Elemental Analysis } \\
\hline & & $\mathrm{Se}$ & $\mathrm{Cd}$ & $\mathrm{Pb}$ & $\mathrm{Ba}$ & $\mathrm{Ag}$ & $\mathrm{Hg}$ & Mo & $\mathrm{Cr}$ & $\mathrm{Be}$ & $\mathrm{V}$ \\
\hline & $\mathrm{cm}$ & \multicolumn{10}{|c|}{$-m g$} \\
\hline Ap1 & $0-10$ & 0.1 & 3.8 & 61.5 & 208.4 & $\mathrm{BDL}$ & $\mathrm{BDL}$ & 5.9 & 21.1 & 1.9 & 44.1 \\
\hline Ap2 & $10-32$ & 0.1 & 0.5 & 35.6 & 230.9 & 0.2 & BDL & BDL & 11.4 & 2.2 & 44.0 \\
\hline Bt1 & $32-53$ & 1.3 & $\overline{B D L}$ & 22.4 & 196.2 & $\overline{B D L}$ & $\overline{B D L}$ & $\overline{B D L}$ & 9.5 & 2.3 & 50.5 \\
\hline $\mathrm{Bt2}$ & $53-75$ & 0.4 & 0.1 & 23.3 & 171.9 & $\overline{B D L}$ & $\overline{\mathrm{BDL}}$ & $\overline{B D L}$ & 22.4 & 4.0 & 74.0 \\
\hline Btss1 & $75-122$ & $\mathrm{BDL}$ & $\overline{B D L}$ & 18.1 & 137.9 & $\overline{B D L}$ & $\overline{B D L}$ & $\overline{B D L}$ & 54.1 & 5.0 & 101.5 \\
\hline Btss2 & $122-165$ & $\mathrm{BDL}$ & 0.5 & 50.7 & 187.4 & $\overline{B D L}$ & $\overline{B D L}$ & $\mathrm{BDL}$ & 60.9 & 7.3 & 100.6 \\
\hline
\end{tabular}

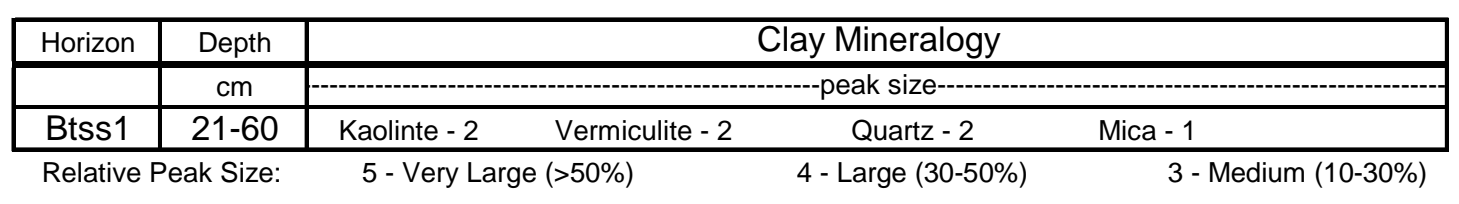

$$
2 \text { - Small (3-10\%) } \quad 1 \text { - Very Small }(<3 \%)
$$




\section{B.4. Swanpond \#2 Site and Profile Description}

Sampled as: Swanpond

Lab \#: S99-WV-003-003 -- Swanpond \#2

Location: Inwood Quarry - Berkeley County

Latitude: $39^{\circ} 20^{\prime} 55^{\prime \prime} \mathrm{N}$; Longitude: $78^{\circ} 02^{\prime} 11^{\prime \prime} \mathrm{W}$

Physiography: Valley and Ridge Province

Land Use and Vegetation: Abandoned hayfield located in a limestone quarry.

Parent Material: Residual - Chambersburg Limestone

Described by: John Sencindiver and Jason Knopp on June 3, 1999

Ap - 0 to $23 \mathrm{~cm}$ (0 to 9 inches); dark brown (10YR 4/3) silt loam; weak coarse subangular blocky structure parting to weak fine and medium granular; friable; common very fine and fine roots; 2 percent gravels; abrupt smooth boundary.

$\mathrm{BE}-23$ to $32 \mathrm{~cm}$ (9 to 12.5 inches); yellowish brown (10YR 5/6) silty clay loam; weak medium subangular blocky structure; friable; few very fine roots; few medium black (N 2.5/0) manganese coatings; root channels filled with material from A horizon; 5 percent gravels and stones; clear wavy boundary.

Btss 1 - 32 to $56 \mathrm{~cm}$ (12.5 to 22 inches); strong brown (7.5YR 5/8) clay; weak coarse prismatic structure parting to moderate medium and coarse subangular blocky; friable; very sticky and very plastic; few very fine roots; common black (N 2.5/0) manganese coatings and concentrations; many continuous distinct clay films; few slickensides 2 to 5 $\mathrm{cm} ; 5$ percent gravels and stones; gradual wavy boundary.

Btss $2-56$ to $88 \mathrm{~cm}$ (22 to 34.5 inches); yellowish brown (10YR 5/8) clay; moderate fine and medium subangular blocky structure; friable; very sticky and very plastic; few very fine roots; common black (N 2.5/0) manganese coatings and concentrations; coarse yellowish red (5YR 4/6) concentrations; many continuous prominent clay films; few slickensides 2 to $5 \mathrm{~cm}$; 5 percent stones; clear wavy boundary.

Btss3 - 88 to $136 \mathrm{~cm}$ (34.5 to 53.5 inches); yellowish brown (10YR 5/8) clay; moderate fine and medium subangular blocky structure; friable; very sticky and very plastic; few very fine roots; few coarse pockets of olive yellow (2.5Y 6/6) and gray ( $\mathrm{N} \mathrm{6/0)} \mathrm{material;}$ few medium strong brown (7.5YR 5/6) concentrations and light brownish gray $(2.5 \mathrm{Y} 6 / 2)$ depletions; common black (N 2.5/0) manganese coatings and concentrations; many continuous distinct clay films; few slickensides 2 to $5 \mathrm{~cm}$; 10 percent stones; gradual wavy boundary.

$\mathrm{BC}-136$ to $163+\mathrm{cm}$ (53.5 to $64+$ inches); mixed white $(\mathrm{N} 8 / 0)$, strong brown (7.5YR $4 / 6)$, very pale brown (10YR 7/3) and yellowish brown (10YR 5/6) silty clay; weak fine subangular blocky structure; friable; few discontinuous faint clay films; 10 percent gravels. 
Note: A large slickenside $10 \mathrm{~cm} \times 20 \mathrm{~cm}$ was found at the bottom of Btss1 and top of Btss2 when sampling. 


\section{B.5. Swanpond \#2 Characterization Data}

\begin{tabular}{|c|c|c|c|c|c|c|c|c|c|}
\hline \multirow{3}{*}{ Horizon } & \multirow{3}{*}{ Depth } & \multicolumn{8}{|c|}{ Particle Size } \\
\hline & & \multicolumn{3}{|c|}{ Total } & \multicolumn{5}{|c|}{ Sand } \\
\hline & & Sand & Silt & Clay & V. Coarse & Coarse & Medium & Fine & V. Fine \\
\hline & $\mathrm{cm}$ & & & & $----\%$ & & & - & \\
\hline Ap & $0-23$ & 17.6 & 54.3 & 28.1 & 1.7 & 3.5 & 4.4 & 3.8 & 4.2 \\
\hline $\mathrm{BE}$ & $23-32$ & 14.6 & 57.6 & 27.8 & 1.5 & 2.7 & 3.9 & 3.1 & 3.4 \\
\hline Btss1 & $32-56$ & 7.3 & 32.9 & 59.8 & 0.8 & 1.1 & 1.7 & 1.6 & 2.1 \\
\hline Btss2 & $56-88$ & 5.1 & 25.8 & 69.1 & 0.3 & 0.6 & 1.1 & 1.4 & 1.7 \\
\hline Btss3 & $88-136$ & 8.9 & 27.1 & 64.0 & 0.5 & 1.4 & 2.2 & 2.5 & 2.3 \\
\hline $\mathrm{BC}$ & $136-163+$ & 4.8 & 31.9 & 63.3 & 0.4 & 0.9 & 1.1 & 1.2 & 1.2 \\
\hline
\end{tabular}

\begin{tabular}{|c|c|c|c|c|c|c|c|}
\hline \multirow{3}{*}{ Horizon } & \multirow{3}{*}{ Depth } & \multicolumn{4}{|c|}{ Bulk Density } & \multirow{2}{*}{\multicolumn{2}{|c|}{ Atterberg Limits }} \\
\hline & & \multicolumn{2}{|c|}{ Oven-Dry } & \multicolumn{2}{|c|}{33 kPA Desorption } & & \\
\hline & & $\mathrm{Db}>2 \mathrm{~mm}$ & $\mathrm{Db}<2 \mathrm{~mm}$ & $\mathrm{Db}>2 \mathrm{~mm}$ & $\mathrm{Db}<2 \mathrm{~mm}$ & Liquid Limit & Plasticity Index \\
\hline & $\mathrm{cm}$ & & g & $n^{-3}-\ldots$ & & & \\
\hline Ap & $0-23$ & 1.58 & 1.52 & 1.50 & 1.45 & 38 & 19 \\
\hline $\mathrm{BE}$ & $23-32$ & 1.73 & 1.70 & 1.67 & 1.64 & 30 & 14 \\
\hline Btss1 & $32-56$ & 1.81 & 1.80 & 1.61 & 1.60 & 59 & 40 \\
\hline Btss2 & $56-88$ & 1.77 & 1.76 & 1.49 & 1.48 & 68 & 47 \\
\hline Btss3 & $88-136$ & 1.80 & 1.79 & 1.50 & 1.50 & 63 & 43 \\
\hline $\mathrm{BC}$ & 136-163+ & -- & -- & -- & -- & 62 & 42 \\
\hline
\end{tabular}

\begin{tabular}{|c|c|c|c|c|c|c|}
\hline \multirow{2}{*}{ Horizon } & \multirow{2}{*}{ Depth } & \multirow{2}{*}{\begin{tabular}{|c|} 
Rock \\
Fragments by \\
Wt.
\end{tabular}} & \multicolumn{3}{|c|}{ Water Retention } & \multirow{2}{*}{ COLE } \\
\hline & & & $33 \mathrm{kPA}$ & $1500 \mathrm{kPA}$ & \multirow{2}{*}{$\frac{\text { WRD }}{\mathrm{cm} \mathrm{cm}^{-1}}$} & \\
\hline & $\mathrm{cm}$ & & ---\%---- & & & \\
\hline$A p$ & $0-23$ & 6.9 & 26.5 & 11.1 & 0.22 & 0.02 \\
\hline $\mathrm{BE}$ & $23-32$ & 6.7 & 26.5 & 10.5 & 0.25 & 0.02 \\
\hline Btss1 & $32-56$ & 2.0 & 31.7 & 22.0 & 0.15 & 0.05 \\
\hline Btss2 & $56-88$ & 1.5 & 38.2 & 25.4 & 0.18 & 0.07 \\
\hline Btss3 & $88-136$ & 0.6 & 38.3 & 23.6 & 0.20 & 0.07 \\
\hline $\mathrm{BC}$ & $136-163+$ & 4.0 & 37.2 & 23.4 & $\overline{--}$ & -- \\
\hline
\end{tabular}

\begin{tabular}{|c|c|c|c|c|c|c|c|c|c|c|c|c|}
\hline \multirow{2}{*}{ Horizon } & \multirow{2}{*}{ Depth } & \multicolumn{6}{|c|}{ Extractable } & \multicolumn{2}{|c|}{ CEC } & \multirow{2}{*}{ ECEC } & \multicolumn{2}{|c|}{ Base Saturation } \\
\hline & & $\mathrm{Ca}$ & $\mathrm{Mg}$ & $\mathrm{Na}$ & $\mathrm{K}$ & Acidity & $\mathrm{Al}$ & CEC-8.2 & CEC-7 & & CEC-8.2 & CEC-7 \\
\hline & $\mathrm{cm}$ & & & & & $-\mathrm{cmol}_{\mathrm{c}} \mathrm{H}$ & & & & & & \\
\hline Ap & $0-23$ & 14.6 & 1.2 & 0.2 & 0.3 & 2.8 & -- & 19.1 & 13.7 & -- & 85.3 & 119.0 \\
\hline $\mathrm{BE}$ & $23-32$ & 9.0 & 0.9 & 0.3 & 0.1 & 2.8 & -- & 13.1 & 9.5 & -- & 78.6 & 108.4 \\
\hline Btss1 & $32-56$ & 16.9 & 6.0 & 0.3 & 0.3 & 3.8 & -- & 27.3 & 21.0 & -- & 86.1 & 111.9 \\
\hline Btss2 & $56-88$ & 16.8 & 10.0 & 0.3 & 0.5 & 4.0 & -- & 31.6 & 24.9 & -- & 87.3 & 110.8 \\
\hline Btss3 & $88-136$ & 17.2 & 11.5 & 0.3 & 0.3 & 2.7 & -- & 32.0 & 25.1 & -- & 91.6 & 116.7 \\
\hline $\mathrm{BC}$ & $136-163+$ & 27.1 & 10.9 & 0.3 & 0.4 & 0.6 & -- & 39.3 & 23.4 & -- & 98.5 & 165.4 \\
\hline
\end{tabular}




\begin{tabular}{|c|c|c|c|c|c|c|c|c|}
\hline \multirow{2}{*}{ Horizon } & \multirow{2}{*}{ Depth } & \multirow{2}{*}{ Al Saturation } & \multicolumn{3}{|c|}{ Total } & \multirow{2}{*}{$\begin{array}{c}\text { Extractable } \\
\text { Mn }\end{array}$} & \multicolumn{2}{|c|}{$\mathrm{pH}$} \\
\hline & & & Carbon & Sulfur & Nitrogen & & 1:1 Water & $1: 2 \mathrm{CaCl}_{2}$ \\
\hline & $\mathrm{cm}$ & & $---\%$ & --- & ----5 & $\mathrm{mg} \mathrm{kg}^{-1}$ & & \\
\hline Ap & $0-23$ & -- & 1.37 & 0.02 & 0.14 & -- & 6.2 & 6.1 \\
\hline $\mathrm{BE}$ & $23-32$ & -- & 0.40 & 0.02 & 0.07 & -- & 6.8 & 6.3 \\
\hline Btss1 & $32-56$ & -- & 0.47 & 0.01 & 0.06 & -- & 7.0 & 6.6 \\
\hline Btss2 & $56-88$ & -- & 0.37 & 0.02 & 0.07 & -- & 7.3 & 7.1 \\
\hline Btss3 & $88-136$ & -- & 0.18 & 0.02 & 0.07 & -- & 7.3 & 7.0 \\
\hline $\mathrm{BC}$ & $136-163+$ & -- & 0.32 & 0.03 & 0.05 & -- & 7.4 & 7.1 \\
\hline
\end{tabular}

\begin{tabular}{|c|c|c|c|c|c|c|c|c|}
\hline \multirow{2}{*}{ Horizon } & \multirow{2}{*}{ Depth } & \multicolumn{7}{|c|}{ Total Elemental Analysis } \\
\hline & & $\mathrm{Fe}$ & $\mathrm{Mn}$ & $\mathrm{Al}$ & $\mathrm{Ca}$ & $\mathrm{Mg}$ & $\mathrm{Na}$ & $\mathrm{K}$ \\
\hline & $\mathrm{cm}$ & & & & $\mathrm{mg} \mathrm{kg}^{-1}$ & & & \\
\hline $\mathrm{Ap}$ & $0-23$ & 25163.5 & 1461.4 & 40746.4 & 3470.1 & 3125.8 & 1240.2 & 1755.1 \\
\hline$B E$ & $23-32$ & 18469.7 & 583.1 & 37389.8 & 2190.1 & 2838.5 & 1360.7 & 1736.8 \\
\hline Btss1 & $32-56$ & 35808.9 & 1266.2 & 70611.6 & 3409.4 & 4192.5 & 929.4 & 2240.6 \\
\hline Btss2 & $56-88$ & 40597.2 & 697.5 & 81806.9 & 3213.8 & 9224.6 & 672.1 & 2434.9 \\
\hline Btss3 & $88-136$ & 32566.5 & 892.3 & 69495.1 & 3209.0 & 8361.9 & 373.4 & 1645.6 \\
\hline$B C$ & $136-163+$ & 18488.7 & 266.5 & 80357.0 & 11151.0 & 12736.4 & 385.9 & 3241.7 \\
\hline
\end{tabular}

\begin{tabular}{|c|c|c|c|c|c|c|c|c|}
\hline \multirow{2}{*}{ Horizon } & \multirow{2}{*}{ Depth } & \multicolumn{7}{|c|}{ Total Elemental Analysis } \\
\hline & & $P$ & $\mathrm{Si}$ & $\mathrm{Cu}$ & $\mathrm{Zn}$ & $\mathrm{Ni}$ & As & Co \\
\hline & $\mathrm{cm}$ & & & & $\mathrm{mg} \mathrm{kg}^{-1}$ & & & \\
\hline Ap & $0-23$ & 401.8 & 133299.8 & 41.0 & 106.7 & 12.7 & 10.6 & 119.5 \\
\hline $\mathrm{BE}$ & $23-32$ & 190.5 & 124795.7 & 31.0 & 81.2 & 8.8 & 8.6 & 91.3 \\
\hline Btss1 & $32-56$ & 194.9 & 132676.6 & 68.0 & 161.2 & 35.4 & 11.0 & 157.0 \\
\hline Btss2 & $56-88$ & 169.4 & 125934.7 & 80.8 & 254.8 & 50.5 & 11.2 & 165.2 \\
\hline Btss3 & $88-136$ & 302.0 & 113473.2 & 58.5 & 364.9 & 31.4 & 10.1 & 134.5 \\
\hline $\mathrm{BC}$ & $136-163+$ & 339.9 & 130885.2 & 48.6 & 114.9 & 23.2 & 4.8 & 71.4 \\
\hline
\end{tabular}

\begin{tabular}{|c|c|c|c|c|c|c|c|c|c|c|c|}
\hline \multirow{2}{*}{ Horizon } & \multirow{2}{*}{ Depth } & \multicolumn{10}{|c|}{ Total Elemental Analysis } \\
\hline & & $\mathrm{Se}$ & $\mathrm{Cd}$ & $\mathrm{Pb}$ & $\mathrm{Ba}$ & $\mathrm{Ag}$ & $\mathrm{Hg}$ & Mo & $\mathrm{Cr}$ & $\mathrm{Be}$ & $\mathrm{V}$ \\
\hline & $\mathrm{cm}$ & \multicolumn{10}{|c|}{$-m g$} \\
\hline$A p$ & $0-23$ & 0.4 & $\mathrm{BDL}$ & 39.2 & 250.6 & $\mathrm{BDL}$ & $\mathrm{BDL}$ & $\mathrm{BDL}$ & 26.3 & 2.4 & 59.5 \\
\hline $\mathrm{BE}$ & $23-32$ & 0.1 & $\mathrm{BDL}$ & 19.3 & 239.5 & $\mathrm{BDL}$ & BDL & BDL & 10.4 & 1.6 & 49.5 \\
\hline Btss1 & $32-56$ & 0.3 & $\mathrm{BDL}$ & 27.3 & 312.9 & $\mathrm{BDL}$ & $\overline{B D L}$ & BDL & 44.0 & 4.2 & 105.5 \\
\hline Btss2 & $56-88$ & $\overline{B D L}$ & $\overline{B D L}$ & 26.9 & 220.8 & $\overline{B D L}$ & $\overline{B D L}$ & $\overline{B D L}$ & 63.8 & 4.9 & 118.4 \\
\hline Btss3 & $88-136$ & $\mathrm{BDL}$ & $\mathrm{BDL}$ & 21.0 & 183.6 & $\mathrm{BDL}$ & $\overline{B D L}$ & $\overline{B D L}$ & 45.3 & 3.3 & 90.9 \\
\hline$B C$ & $136-163+$ & 0.2 & BDL & 21.3 & 142.6 & BDL & $\mathrm{BDL}$ & BDL & 68.0 & 1.7 & 103.0 \\
\hline
\end{tabular}

\begin{tabular}{|c|c|c|c|c|c|c|}
\hline Horizon & Depth & \multicolumn{5}{|c|}{ Clay Mineralogy } \\
\hline & $\mathrm{cm}$ & \multicolumn{5}{|c|}{ k size- } \\
\hline Btss2 & $56-88$ & Mica - 3 & Kaolinite - 2 & Montmorillonite - 1 & Vermiculite - 1 & Geothite - 1 \\
\hline
\end{tabular}

$$
2 \text { - Small (3-10\%) } \quad 1 \text { - Very Small }(<3 \%)
$$




\section{B.6. Swanpond \#3 Site and Profile Description}

Sampled as: Swanpond

Lab \#: S99-WV-003-004 -- Swanpond \#3

Location: Type Location -- John Welch Farm - Berkeley County

Latitude: $39^{\circ} 28^{\prime} 13^{\prime \prime} \mathrm{N}$; Longitude: $77^{\circ} 53^{\prime} 26^{\prime \prime} \mathrm{W}$

Physiography: Valley and Ridge Province

Slope: $1.5 \%$

Elevation: $135 \mathrm{~m} \pm 9.7 \mathrm{~m}(444 \mathrm{ft} . \pm 32 \mathrm{ft}$.

Land Use and Vegetation: Hayfield

Parent Material: Residual - Chambersburg Limestone

Described by: James Bell, Brian Cooley, Jason Knopp, John Sencindiver and Bill Bates

on June 15, 1999

Ap1 - 0 to $8 \mathrm{~cm}$ (0 to 3 inches); brown (10YR 4/3) silt loam; moderate fine and medium granular structure; friable; many very fine and fine roots; 1 percent rock fragments; clear wavy boundary.

Ap2 -8 to $23 \mathrm{~cm}$ (3 to 9 inches); dark yellowish brown (10YR 4/4) silt loam; weak fine and medium subangular blocky structure; friable; common very fine and fine roots; abrupt smooth boundary.

Bt1 -23 to $36 \mathrm{~cm}$ (9 to 14 inches); strong brown (7.5YR 4/6) silty clay; moderate medium subangular blocky structure; extremely hard (dry); firm (moist); moderately sticky and moderately plastic; common very fine and fine roots; many continuous dark yellowish brown (10YR 4/4) organic films on ped faces; few patchy faint clay films on ped faces; clear wavy boundary.

Bt2 -36 to $64 \mathrm{~cm}$ (14 to 25 inches); strong brown (7.5YR 4/6) clay; weak very coarse prismatic structure parting to moderate medium subangular blocky; extremely hard (dry); firm (moist); very sticky and very plastic; few very fine and fine roots; common discontinuous distinct clay films on ped faces; gradual wavy boundary.

Btss1 - 64 to $88 \mathrm{~cm}$ (25 to 34.5 inches); yellowish brown (10YR 5/8) clay; moderate very coarse prismatic structure parting to moderate medium subangular blocky; extremely hard (dry); firm (moist); very sticky and very plastic; few very fine roots; many

continuous distinct clay films on ped faces; common intersecting slickensides 4 to $16 \mathrm{~cm}$; clear wavy boundary.

Btss 2 - 88 to $101 \mathrm{~cm}$ (34.5 to 40 inches); yellowish brown (10YR 5/6) clay; moderate very coarse prismatic structure parting to moderate very fine and fine angular blocky; extremely hard (dry); firm (moist); very sticky and very plastic; very few very fine roots; common fine gray (10YR 6/1) depletions; few fine yellowish red (5YR 5/8) concentrations; many continuous distinct clay films; common intersecting slickensides 2.5 to $9 \mathrm{~cm}$; clear wavy boundary. 
Btss3 - 101 to $128 \mathrm{~cm}$ (40 to 50.5 inches); yellowish brown (10YR 5/6) clay; moderate very coarse prismatic structure parting to moderate very fine and fine angular blocky; extremely hard (dry); firm (moist); very sticky and very plastic; very few very fine roots; many fine and medium gray (10YR 6/1) depletions; common fine and medium yellowish red (5YR 5/8) concentrations; many continuous distinct clay films; common intersecting slickensides 8 to $19 \mathrm{~cm}$; gradual wavy boundary.

Btss4 - 128 to $160+\mathrm{cm}(50.5$ to $63+$ inches); yellowish brown (10YR 5/6) clay; moderate very coarse prismatic structure parting to moderate very fine and fine angular blocky; extremely hard (dry); firm (moist); very sticky and very plastic; very few very fine roots; black manganese coatings; few fine light gray (10YR 7/1) and very pale brown (10YR 7/3) depletions; many medium and coarse dark red (2.5YR 4/6) concentrations; many continuous distinct clay films; common large intersecting slickensides.

Note: This pedon is the Type Location for the Swanpond series. Cracks with a width of 1 to $8 \mathrm{~mm}$ exist 15 to $20 \mathrm{~cm}$ apart beginning at the bottom of the Ap2 and extending into Btss4. Slickensides in the Btss2 horizon were tilted at 15 to 35 degrees from the horizontal. Slickensides in the Btss 3 horizon were tilted at 30 degrees from the horizontal. 


\section{B.7. Swanpond \#3 Characterization Data}

\begin{tabular}{|c|c|c|c|c|c|c|c|c|c|}
\hline \multirow{3}{*}{ Horizon } & \multirow{3}{*}{ Depth } & \multicolumn{8}{|c|}{ Particle Size } \\
\hline & & \multicolumn{3}{|c|}{ Total } & \multicolumn{5}{|c|}{ Sand } \\
\hline & & Sand & Silt & Clay & V. Coarse & Coarse & Medium & Fine & V. Fine \\
\hline & $\mathrm{cm}$ & & & & ---\%- & 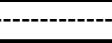 & & $\cdots$ & - \\
\hline Ap1 & $0-8$ & 6.8 & 63.7 & 29.5 & 0.5 & 1.2 & 1.5 & 1.3 & 2.3 \\
\hline Ap2 & $8-23$ & 7.4 & 61.4 & 31.2 & 1.0 & 1.5 & 1.5 & 1.3 & 2.1 \\
\hline Bt1 & $23-36$ & 5.4 & 51.3 & 43.3 & $\overline{0.4}$ & 1.0 & 1.0 & 1.1 & 1.9 \\
\hline Bt2 & $36-64$ & 3.0 & 26.5 & 70.5 & 0.1 & 0.2 & 0.4 & 0.7 & 1.6 \\
\hline Btss1 & $64-88$ & 4.3 & 34.8 & 60.9 & 0.4 & 0.5 & 0.8 & 0.9 & 1.7 \\
\hline Btss2 & $88-101$ & 2.5 & 22.3 & 75.2 & 0.1 & 0.2 & 0.3 & 0.5 & 1.4 \\
\hline Btss3 & $101-128$ & 1.9 & 20.3 & 77.8 & 0.0 & 0.1 & 0.2 & 0.4 & 1.2 \\
\hline Btss4 & 128-160+ & 2.5 & 21.4 & 76.1 & 0.1 & 0.1 & 0.2 & 0.5 & 1.6 \\
\hline
\end{tabular}

\begin{tabular}{|c|c|c|c|c|c|c|c|}
\hline \multirow{3}{*}{ Horizon } & \multirow{3}{*}{ Depth } & \multicolumn{4}{|c|}{ Bulk Density } & \multirow{2}{*}{\multicolumn{2}{|c|}{ Atterberg Limits }} \\
\hline & & \multicolumn{2}{|c|}{ Oven-Dry } & \multicolumn{2}{|c|}{33 kPA Desorption } & & \\
\hline & & $\mathrm{Db}>2 \mathrm{~mm}$ & $\mathrm{Db}<2 \mathrm{~mm}$ & $\mathrm{Db}>2 \mathrm{~mm}$ & $\mathrm{Db}<2 \mathrm{~mm}$ & Liquid Limit & Plasticity Index \\
\hline & $\mathrm{cm}$ & & $---g$ & 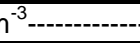 & 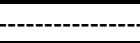 & & \\
\hline Ap1 & $0-8$ & 1.61 & 1.60 & 1.55 & 1.54 & 47 & 20 \\
\hline Ap2 & $8-23$ & 1.76 & 1.75 & 1.68 & 1.67 & 39 & 20 \\
\hline Bt1 & $23-36$ & 1.75 & 1.74 & 1.63 & 1.63 & 42 & 25 \\
\hline Bt2 & $36-64$ & 1.84 & 1.83 & 1.61 & 1.61 & 75 & 52 \\
\hline Btss1 & $64-88$ & 1.77 & 1.77 & 1.50 & 1.50 & 56 & 37 \\
\hline Btss2 & $88-101$ & 1.77 & 1.76 & 1.57 & 1.57 & 85 & 61 \\
\hline Btss3 & $101-128$ & 1.76 & 1.76 & 1.55 & 1.54 & 75 & 53 \\
\hline Btss4 & $128-160+$ & 1.78 & 1.78 & 1.54 & 1.54 & 79 & 57 \\
\hline
\end{tabular}

\begin{tabular}{|c|c|c|c|c|c|c|}
\hline \multirow{2}{*}{ Horizon } & \multirow{2}{*}{ Depth } & \multirow{2}{*}{\begin{tabular}{|c|} 
Rock \\
Fragments by \\
Wt.
\end{tabular}} & \multicolumn{3}{|c|}{ Water Retention } & \multirow{2}{*}{ COLE } \\
\hline & & & $33 \mathrm{kPA}$ & $1500 \mathrm{kPA}$ & \multirow{2}{*}{$\frac{\text { WRD }}{\mathrm{cm} \mathrm{cm}^{-1}}$} & \\
\hline & $\mathrm{cm}$ & |----------- & ----\%---- & --------- & & \\
\hline Ap1 & $0-8$ & 0.6 & 32.3 & 13.3 & 0.29 & 0.02 \\
\hline Ap2 & $8-23$ & 1.2 & 28.1 & 12.7 & 0.26 & 0.02 \\
\hline Bt1 & $23-36$ & 0.4 & 29.0 & 17.1 & 0.19 & 0.03 \\
\hline $\mathrm{Bt} 2$ & $36-64$ & 0.0 & 41.5 & 26.4 & 0.24 & 0.05 \\
\hline Btss1 & $64-88$ & 0.5 & 35.2 & 22.7 & 0.19 & 0.07 \\
\hline Btss2 & $88-101$ & 0.0 & 43.0 & 27.2 & 0.25 & 0.05 \\
\hline Btss3 & $101-128$ & 0.0 & 43.8 & 28.3 & 0.24 & 0.06 \\
\hline Btss4 & 128-160+ & 0.0 & 43.4 & 27.8 & 0.24 & 0.06 \\
\hline
\end{tabular}




\begin{tabular}{|c|c|c|c|c|c|c|c|c|c|c|c|c|}
\hline \multirow{2}{*}{ Horizon } & \multirow{2}{*}{ Depth } & \multicolumn{6}{|c|}{ Extractable } & \multicolumn{2}{|c|}{ CEC } & \multirow{2}{*}{ ECEC } & \multicolumn{2}{|c|}{ Base Saturation } \\
\hline & & $\mathrm{Ca}$ & $\mathrm{Mg}$ & $\mathrm{Na}$ & $\mathrm{K}$ & Acidity & $\mathrm{Al}$ & CEC-8.2 & CEC-7 & & CEC-8.2 & CEC-7 \\
\hline & $\mathrm{cm}$ & & & & & $-\mathrm{cmol}_{\mathrm{c}}$ & & & & & & \\
\hline Ap1 & $0-8$ & 12.5 & 1.8 & 0.2 & 0.6 & 7.9 & -- & 23.0 & 16.2 & $\overline{--}$ & 65.7 & 93.2 \\
\hline Ap2 & $8-23$ & 13.3 & 1.1 & 0.2 & 0.2 & 5.2 & -- & 20.0 & 14.5 & $\overline{--}$ & 74.0 & 102.1 \\
\hline Bt1 & $23-36$ & 14.3 & 1.0 & 0.3 & 0.5 & 4.2 & -- & 20.3 & 15.5 & -- & 79.3 & 103.9 \\
\hline Bt2 & $36-64$ & 17.3 & 1.3 & 0.2 & 0.3 & 13.9 & -- & 33.0 & 26.2 & - & 57.9 & 72.9 \\
\hline Btss1 & $64-88$ & 19.4 & 1.1 & 0.3 & 0.4 & 5.5 & -- & 26.7 & 22.3 & -- & 79.4 & 95.1 \\
\hline Btss2 & 88-101 & 16.8 & 1.5 & 0.3 & 0.3 & 15.6 & 6.2 & 34.5 & 28.4 & 25.1 & 54.8 & 66.5 \\
\hline Btss3 & 101-128 & 19.1 & 1.8 & 0.3 & 0.4 & 13.1 & 4.7 & 34.7 & 29.4 & 26.3 & 62.2 & 73.5 \\
\hline Btss4 & 128-160+ & 22.9 & 2.2 & 0.3 & 0.4 & 8.3 & 0.7 & 34.1 & 28.6 & 26.5 & 75.7 & 90.2 \\
\hline
\end{tabular}

\begin{tabular}{|c|c|c|c|c|c|c|c|c|}
\hline \multirow{2}{*}{ Horizon } & \multirow{2}{*}{ Depth } & \multirow{2}{*}{ Al Saturation } & \multicolumn{3}{|c|}{ Total } & \multirow{2}{*}{$\begin{array}{c}\text { Extractable } \\
\text { Mn }\end{array}$} & \multicolumn{2}{|c|}{$\mathrm{pH}$} \\
\hline & & & Carbon & Sulfur & Nitrogen & & 1:1 Water & $1: 2 \mathrm{CaCl}_{2}$ \\
\hline & $\mathrm{cm}$ & & $---0 \%$ & & & $\mathrm{mg} \mathrm{kg}^{-1}$ & & \\
\hline Ap1 & $0-8$ & $\overline{--}$ & 2.47 & 0.06 & 0.25 & -- & 6.9 & 6.2 \\
\hline Ap2 & $8-23$ & -- & 1.21 & 0.06 & 0.14 & -- & 6.7 & 6.6 \\
\hline Bt1 & $23-36$ & $\overline{--}$ & 0.45 & 0.05 & 0.09 & $\overline{--}$ & 6.9 & 6.4 \\
\hline Bt2 & $36-64$ & $\overline{--}$ & 0.28 & 0.06 & 0.06 & -- & 5.7 & 5.2 \\
\hline Btss1 & $64-88$ & $\overline{--}$ & 0.36 & 0.04 & 0.09 & $\overline{--}$ & 6.2 & 5.8 \\
\hline Btss2 & $88-101$ & 24.7 & 0.20 & 0.06 & 0.07 & 0.20 & 5.4 & 4.4 \\
\hline Btss3 & $101-128$ & 17.9 & 0.18 & 0.06 & 0.07 & $\mathrm{BDL}$ & 5.1 & 4.5 \\
\hline Btss4 & 128-160+ & 2.6 & 0.17 & 0.04 & 0.09 & 1.90 & 5.4 & 4.9 \\
\hline
\end{tabular}

\begin{tabular}{|c|c|c|c|c|c|c|c|c|}
\hline \multirow{2}{*}{ Horizon } & \multirow{2}{*}{ Depth } & \multicolumn{7}{|c|}{ Total Elemental Analysis } \\
\hline & & $\mathrm{Fe}$ & $\mathrm{Mn}$ & $\mathrm{Al}$ & $\mathrm{Ca}$ & $\mathrm{Mg}$ & $\mathrm{Na}$ & $\mathrm{K}$ \\
\hline & $\mathrm{cm}$ & & & & $-\mathrm{mg} \mathrm{kg}^{-1}$ & & & \\
\hline Ap1 & $0-8$ & 22956.3 & 2002.6 & 23958.2 & 2382.8 & 1379.7 & 1763.5 & 924.6 \\
\hline Ap2 & $8-23$ & 23694.7 & 2009.6 & 41129.4 & 3137.0 & 2673.2 & 1617.2 & 1044.9 \\
\hline Bt1 & $23-36$ & 28376.7 & 624.1 & 41169.0 & 2613.1 & 2060.9 & 1441.7 & 1079.0 \\
\hline Bt2 & $36-64$ & 42099.0 & 151.1 & 52835.7 & 2969.5 & 4239.2 & 626.6 & 1090.5 \\
\hline Btss1 & $64-88$ & 36473.1 & 360.2 & 61092.6 & 3375.6 & 3871.2 & 1123.6 & 1191.6 \\
\hline Btss2 & $88-101$ & 39021.4 & 77.4 & 76646.1 & 3092.4 & 4453.8 & 470.8 & 1021.2 \\
\hline Btss3 & $101-128$ & 41623.3 & 76.1 & 81009.9 & 3429.2 & 4279.8 & 379.3 & 990.7 \\
\hline Btss4 & $128-160+$ & 40586.4 & 303.7 & 77582.3 & 3854.2 & 4477.1 & 454.3 & 1081.7 \\
\hline
\end{tabular}

\begin{tabular}{|c|c|c|c|c|c|c|c|c|}
\hline \multirow{2}{*}{ Horizon } & \multirow{2}{*}{ Depth } & \multicolumn{7}{|c|}{ Total Elemental Analysis } \\
\hline & & $\mathrm{P}$ & Si & $\mathrm{Cu}$ & $\mathrm{Zn}$ & $\mathrm{Ni}$ & As & Co \\
\hline & $\mathrm{cm}$ & & & & $\mathrm{mg} \mathrm{kg}^{-1}$ & & & \\
\hline Ap1 & $0-8$ & 1291.5 & 114937.8 & 28.8 & 588.3 & 13.4 & 6.4 & 65.7 \\
\hline Ap2 & $8-23$ & 853.2 & 141122.1 & 30.7 & 110.1 & 20.1 & 8.0 & 74.5 \\
\hline Bt1 & $23-36$ & 397.9 & 148054.9 & 40.6 & 223.2 & 27.2 & 7.6 & 82.0 \\
\hline Bt2 & $36-64$ & 377.0 & 132961.6 & 56.5 & 131.9 & 45.3 & 7.9 & 103.6 \\
\hline Btss1 & $64-88$ & 422.3 & 148270.6 & 51.8 & 124.2 & 34.7 & 8.6 & 98.5 \\
\hline Btss2 & $88-101$ & 244.2 & 115672.3 & 67.9 & 108.5 & 30.6 & 6.9 & 97.1 \\
\hline Btss3 & $101-128$ & 290.3 & 111090.5 & 69.5 & 109.3 & 30.8 & 6.5 & 104.8 \\
\hline Btss4 & $128-160+$ & 288.9 & 124321.9 & 68.9 & 124.8 & 35.3 & 6.5 & 110.3 \\
\hline
\end{tabular}




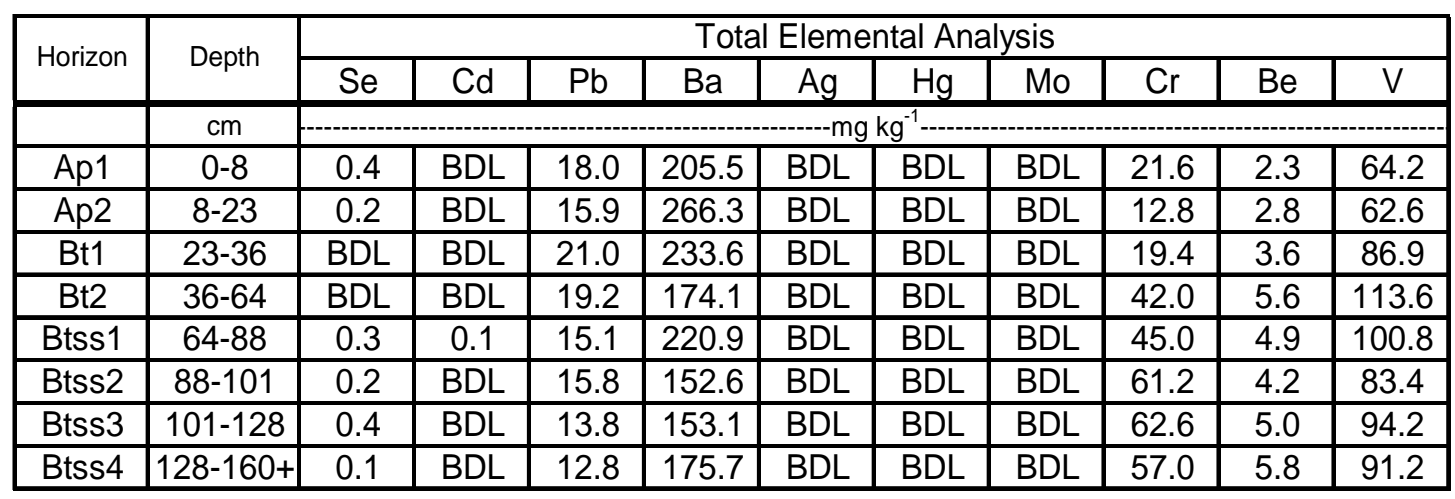

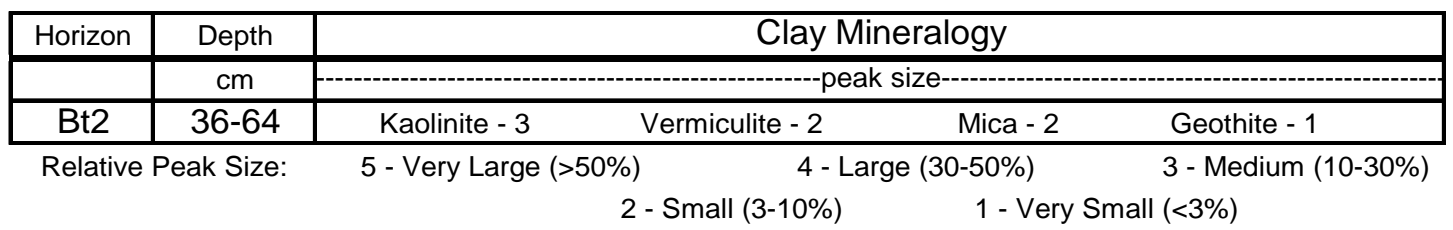




\section{B.8. Swanpond \#4 Site and Profile Description}

Sampled as: Swanpond

Lab \#: S99-WV-003-005 -- Swanpond \#4

Location: Stewart Farm near Inwood - Berkeley County

Latitude: $39^{\circ} 23^{\prime} 32^{\prime \prime} \mathrm{N}$; Longitude: $78^{\circ} 00^{\prime} 39^{\prime \prime} \mathrm{W}$

Physiography: Valley and Ridge Province

Slope: $1.5 \%$

Elevation: $161.7 \mathrm{~m} \pm 12.2 \mathrm{~m}(532 \mathrm{ft} . \pm 40 \mathrm{ft}$.

Land Use and Vegetation: Hayfield

Parent Material: Residual - Beekmantown Limestone

Described by: James Bell, Brian Cooley, Bill Bates and Jason Knopp on June 18, 1999

Ap -0 to $20 \mathrm{~cm}$ (0 to 8 inches); dark yellowish brown (10YR 4/4) silty clay loam; weak medium subangular blocky structure parting to moderate fine granular; friable; common very fine to coarse roots; 1 percent chert and limestone channers; abrupt smooth boundary.

$\mathrm{Bt}-20$ to $51 \mathrm{~cm}$ (8 to 20 inches); yellowish brown (10YR 5/6) clay; weak coarse and very coarse prismatic structure parting to moderate medium subangular blocky; firm; very sticky and very plastic; few very fine to coarse roots; 2 percent dark yellowish brown (10YR 4/4) krotovina $5 \mathrm{~mm}$ diameter; common discontinuous distinct clay films in pores and on ped faces; 2 percent limestone channers; gradual wavy boundary.

Btss 1 - 51 to $78 \mathrm{~cm}$ (20 to 30.5 inches); yellowish brown (10YR 5/6) clay; many medium and coarse strong brown (7.5YR 5/6) mottles; weak coarse prismatic structure parting to moderate fine and medium angular blocky; firm; very sticky and very plastic; few very fine and fine roots; 1 percent dark yellowish brown (10YR 4/4) krotovina $5 \mathrm{~mm}$ diameter; common discontinuous distinct clay films on ped faces; few slickensides $1.5 \mathrm{~cm} ; 2$ percent limestone channers; gradual wavy boundary.

Btss2 - 78 to $117 \mathrm{~cm}$ (30.5 to 46 inches); yellowish brown (10YR 5/6) clay; common medium yellowish red (5YR 4/6) mottles; few medium brown (10YR 5/3) mottles; weak coarse prismatic structure parting to moderate very fine and fine angular blocky; friable; very sticky and very plastic; few very fine to medium roots; 1 percent dark yellowish brown (10YR 4/4) krotovina $5 \mathrm{~mm}$ diameter; many continuous distinct clay films on ped faces; common slickensides 5 to $15 \mathrm{~cm}$; 1 percent limestone channers; gradual wavy boundary. 
Btss3 - 117 to $138 \mathrm{~cm}$ (46 to 54.5 inches); yellowish brown (10YR 5/6) clay; few medium yellowish red (5YR 4/6) and brown (10YR 5/3) mottles; weak coarse prismatic structure parting to strong very fine and fine angular blocky; friable; very sticky and very plastic; very few very fine roots; many fine and medium black manganese stains on peds; many continuous distinct clay films on ped faces; common slickensides 5 to $10 \mathrm{~cm}$; 1 percent limestone channers; abrupt irregular boundary.

$\mathrm{R}-138+\mathrm{cm}(54.5+$ inches $)$; limestone bedrock

Notes: The first $6 \mathrm{~cm}$ of the surface horizon contained more roots and was more friable than the rest of the horizon, but was not described because it was too thin to sample.

Cracks with a width of 1 to $3 \mathrm{~mm}$ exist 18 to $36 \mathrm{~cm}$ apart beginning at the bottom of the Ap and extending to the bottom of the Bt. 


\section{B.9. Swanpond \#4 Characterization Data}

\begin{tabular}{|c|c|c|c|c|c|c|c|c|c|}
\hline \multirow{3}{*}{ Horizon } & \multirow{3}{*}{ Depth } & \multicolumn{8}{|c|}{ Particle Size } \\
\hline & & \multicolumn{3}{|c|}{ Total } & \multicolumn{5}{|c|}{ Sand } \\
\hline & & Sand & Silt & Clay & V. Coarse & Coarse & Medium & Fine & V. Fine \\
\hline & $\mathrm{cm}$ & & & & $--0 \%$ & & & & \\
\hline Ap & $0-20$ & 9.5 & 55.6 & 34.9 & 1.4 & 1.9 & 1.9 & 1.8 & 2.5 \\
\hline $\mathrm{Bt}$ & $20-51$ & 2.6 & 18.2 & 79.2 & 0.2 & 0.4 & 0.5 & 0.6 & 0.9 \\
\hline Btss1 & $51-78$ & 2.0 & 19.5 & 78.5 & 0.1 & 0.3 & 0.4 & 0.6 & 0.6 \\
\hline Btss2 & $78-117$ & 2.0 & 12.4 & 85.6 & 0.1 & 0.2 & 0.3 & 0.5 & 0.9 \\
\hline Btss3 & $117-138$ & 2.8 & 18.3 & 78.9 & 0.3 & 0.3 & 0.5 & 0.8 & 0.9 \\
\hline
\end{tabular}

\begin{tabular}{|c|c|c|c|c|c|c|c|}
\hline \multirow{3}{*}{ Horizon } & \multirow{3}{*}{ Depth } & \multicolumn{4}{|c|}{ Bulk Density } & \multirow{2}{*}{\multicolumn{2}{|c|}{ Atterberg Limits }} \\
\hline & & \multicolumn{2}{|c|}{ Oven-Dry } & \multicolumn{2}{|c|}{33 kPA Desorption } & & \\
\hline & & $\mathrm{Db}>2 \mathrm{~mm}$ & $\mathrm{Db}<2 \mathrm{~mm}$ & $\mathrm{Db}>2 \mathrm{~mm}$ & $\mathrm{Db}<2 \mathrm{~mm}$ & Liquid Limit & Plasticity Index \\
\hline & $\mathrm{cm}$ & & $-\mathrm{g}$ & $n^{-3--}$ & & & \\
\hline$A p$ & $0-20$ & 1.67 & 1.64 & 1.61 & 1.58 & 37 & 18 \\
\hline $\mathrm{Bt}$ & $20-51$ & 1.71 & 1.70 & 1.43 & 1.42 & 68 & 44 \\
\hline Btss1 & $51-78$ & 1.71 & 1.70 & 1.49 & 1.48 & 66 & 44 \\
\hline Btss2 & $78-117$ & 1.69 & 1.69 & 1.48 & 1.47 & 85 & 57 \\
\hline Btss3 & $117-138$ & 1.65 & 1.64 & 1.42 & 1.42 & 68 & 45 \\
\hline
\end{tabular}

\begin{tabular}{|c|c|c|c|c|c|c|}
\hline \multirow{2}{*}{ Horizon } & \multirow{2}{*}{ Depth } & \multirow{2}{*}{\begin{tabular}{|c|} 
Rock \\
Fragments by \\
Wt.
\end{tabular}} & \multicolumn{3}{|c|}{ Water Retention } & \multirow{2}{*}{ COLE } \\
\hline & & & $33 \mathrm{kPA}$ & $1500 \mathrm{kPA}$ & \multirow{2}{*}{$\begin{array}{l}\frac{\text { WRD }}{\mathrm{cm} \mathrm{cm}^{-1}} \\
\end{array}$} & \\
\hline & $\mathrm{cm}$ & & ---\%---- & 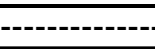 & & \\
\hline$A p$ & $0-20$ & 4.7 & 27.3 & 12.8 & 0.23 & 0.02 \\
\hline $\mathrm{Bt}$ & $20-51$ & 0.4 & 41.8 & 29.1 & 0.18 & 0.07 \\
\hline Btss1 & $51-78$ & 0.3 & 38.5 & 28.8 & 0.14 & 0.05 \\
\hline Btss2 & $78-117$ & 3.4 & 40.5 & 30.2 & 0.15 & 0.05 \\
\hline Btss3 & $117-138$ & 0.1 & 39.1 & 27.9 & 0.16 & 0.06 \\
\hline
\end{tabular}

\begin{tabular}{|c|c|c|c|c|c|c|c|c|c|c|c|c|}
\hline \multirow{2}{*}{ Horizon } & \multirow{2}{*}{ Depth } & \multicolumn{6}{|c|}{ Extractable } & \multicolumn{2}{|c|}{ CEC } & \multirow{2}{*}{ ECEC } & \multicolumn{2}{|c|}{ Base Saturation } \\
\hline & & $\mathrm{Ca}$ & $\mathrm{Mg}$ & $\mathrm{Na}$ & $\mathrm{K}$ & Acidity & $\mathrm{Al}$ & CEC-8.2 & CEC-7 & & CEC-8.2 & CEC-7 \\
\hline & $\mathrm{cm}$ & \multicolumn{9}{|c|}{ - $\mathrm{mol}_{\mathrm{c}} \mathrm{kg}^{-1}$} & \multicolumn{2}{|c|}{--------\%"-----י } \\
\hline Ap & $0-20$ & 8.3 & 1.2 & 0.2 & 0.5 & 7.9 & -- & 18.1 & 13.4 & -- & 56.4 & 76.1 \\
\hline $\mathrm{Bt}$ & $20-51$ & 17.4 & 4.4 & 0.3 & 0.5 & 9.8 & -- & 32.4 & 25.4 & - & 69.8 & 89.0 \\
\hline Btss1 & $51-78$ & 11.3 & 7.2 & 0.3 & 0.4 & 13.7 & 3.1 & 32.9 & 24.8 & 22.3 & 58.4 & 77.4 \\
\hline Btss2 & 78-117 & 11.6 & 8.0 & 0.3 & 0.5 & 16.0 & 4.9 & 36.4 & 29.2 & 25.3 & 56.0 & 69.9 \\
\hline Btss3 & $117-138$ & 12.5 & 9.8 & 0.3 & 0.4 & 9.9 & -- & 32.9 & 27.8 & -- & 69.9 & 82.7 \\
\hline
\end{tabular}

\begin{tabular}{|c|c|c|c|c|c|c|c|c|}
\hline \multirow{2}{*}{ Horizon } & \multirow{2}{*}{ Depth } & \multirow{2}{*}{ Al Saturation } & \multicolumn{3}{|c|}{ Total } & \multirow{2}{*}{$\begin{array}{c}\text { Extractable } \\
\text { Mn }\end{array}$} & \multicolumn{2}{|c|}{$\mathrm{pH}$} \\
\hline & & & Carbon & Sulfur & Nitrogen & & 1:1 Water & $1: 2 \mathrm{CaCl}_{2}$ \\
\hline & $\mathrm{cm}$ & & $---\%$ & & & $\mathrm{mg} \mathrm{kg}^{-1}$ & & \\
\hline$A p$ & $0-20$ & -- & 1.40 & 0.04 & 0.16 & -- & 5.5 & 5.6 \\
\hline $\mathrm{Bt}$ & $20-51$ & -- & 0.38 & 0.02 & 0.06 & -- & 5.9 & 5.2 \\
\hline Btss1 & $51-78$ & 13.9 & 0.22 & 0.03 & 0.07 & 1.30 & 5.5 & 4.6 \\
\hline Btss2 & $78-117$ & 19.4 & 0.22 & 0.03 & 0.04 & 0.30 & 5.3 & 4.5 \\
\hline Btss3 & $117-138$ & -- & 0.18 & 0.02 & 0.06 & -- & 5.5 & 5.1 \\
\hline
\end{tabular}




\begin{tabular}{|c|c|c|c|c|c|c|c|c|}
\hline \multirow{2}{*}{ Horizon } & \multirow{2}{*}{ Depth } & \multicolumn{7}{|c|}{ Total Elemental Analysis } \\
\hline & & $\mathrm{Fe}$ & $\mathrm{Mn}$ & $\mathrm{Al}$ & $\mathrm{Ca}$ & $\mathrm{Mg}$ & $\mathrm{Na}$ & $\mathrm{K}$ \\
\hline & $\mathrm{cm}$ & & & & $-\mathrm{mg} \mathrm{kg}^{-1}$ & & & \\
\hline Ap & $0-20$ & 29552.0 & 2734.9 & 40536.1 & 1625.7 & 2363.1 & 1424.6 & 1525.0 \\
\hline $\mathrm{Bt}$ & $20-51$ & 38179.7 & 163.4 & 72823.1 & 2334.4 & 4129.5 & 518.3 & 1426.4 \\
\hline Btss1 & $51-78$ & 40167.0 & 157.6 & 87894.2 & 1690.8 & 5278.3 & 515.3 & 1852.2 \\
\hline Btss2 & $78-117$ & 41688.4 & 113.8 & 91674.4 & 1575.3 & 5405.4 & 480.3 & 1330.2 \\
\hline Btss3 & $117-138$ & 42100.1 & 265.8 & 81518.4 & 1932.8 & 4903.2 & 494.2 & 1894.1 \\
\hline
\end{tabular}

\begin{tabular}{|c|c|c|c|c|c|c|c|c|}
\hline \multirow{2}{*}{ Horizon } & \multirow{2}{*}{ Depth } & \multicolumn{7}{|c|}{ Total Elemental Analysis } \\
\hline & & $P$ & $\mathrm{Si}$ & $\mathrm{Cu}$ & $\mathrm{Zn}$ & $\mathrm{Ni}$ & As & Co \\
\hline & $\mathrm{cm}$ & & & & $-\mathrm{mg} \mathrm{kg}^{-}$ & & & \\
\hline Ap & $0-20$ & 475.4 & 128485.0 & 45.3 & 84.0 & 17.6 & 11.6 & 129.5 \\
\hline $\mathrm{Bt}$ & $20-51$ & 153.2 & 124745.7 & 64.1 & 112.1 & 41.8 & 10.6 & 155.5 \\
\hline Btss1 & $51-78$ & 121.7 & 127499.2 & 70.8 & 112.9 & 50.5 & 8.9 & 181.6 \\
\hline Btss2 & $78-117$ & 68.6 & 123378.0 & 79.5 & 126.0 & 41.4 & 9.4 & 195.8 \\
\hline Btss3 & $117-138$ & 85.3 & 132542.8 & 86.5 & 140.3 & 49.3 & 8.0 & 208.5 \\
\hline
\end{tabular}

\begin{tabular}{|c|c|c|c|c|c|c|c|c|c|c|c|}
\hline \multirow{2}{*}{ Horizon } & \multirow{2}{*}{ Depth } & \multicolumn{10}{|c|}{ Total Elemental Analysis } \\
\hline & & $\mathrm{Se}$ & $\mathrm{Cd}$ & $\mathrm{Pb}$ & $\mathrm{Ba}$ & $\mathrm{Ag}$ & $\mathrm{Hg}$ & Mo & $\mathrm{Cr}$ & $\mathrm{Be}$ & $\mathrm{V}$ \\
\hline & $\mathrm{cm}$ & & & & & $m$ & $g^{-1}$ & & & & \\
\hline Ap & $0-20$ & 0.5 & 0.6 & 39.2 & 313.0 & $\overline{\mathrm{BDL}}$ & BDL & $\mathrm{BDL}$ & 26.7 & 3.4 & 72.7 \\
\hline $\mathrm{Bt}$ & $20-51$ & 0.6 & 0.7 & 21.0 & 129.1 & $\overline{\mathrm{BDL}}$ & $\overline{B D L}$ & $\mathrm{BDL}$ & 46.7 & 4.9 & 106.2 \\
\hline Btss1 & $51-78$ & 0.3 & $\mathrm{BDL}$ & 35.4 & 133.0 & $\mathrm{BDL}$ & BDL & $\mathrm{BDL}$ & 47.0 & 5.7 & 112.2 \\
\hline Btss2 & $78-117$ & 0.5 & 0.4 & 28.7 & 126.1 & BDL & $\mathrm{BDL}$ & $\mathrm{BDL}$ & 57.5 & 5.9 & 125.5 \\
\hline Btss3 & $117-138$ & $\mathrm{BDL}$ & 0.4 & 36.1 & 158.3 & $\overline{B D L}$ & $\overline{B D L}$ & $\mathrm{BDL}$ & 61.8 & 7.1 & 135.3 \\
\hline
\end{tabular}

\begin{tabular}{|c|c|c|c|c|c|}
\hline Horizon & Depth & \multicolumn{4}{|c|}{ Clay Mineralogy } \\
\hline & $\mathrm{cm}$ & & - & 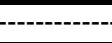 & \\
\hline Btss1 & $51-78$ & Kaolinite - 2 & Vermiculite - 2 & Mica - 1 & Geothite - 1 \\
\hline \multicolumn{2}{|l|}{ Relative } & 5 - Very Large & & $0-50 \%)$ & 3 - Medium (10-30\%) \\
\hline
\end{tabular}




\section{Appendix C}

C.1. Hagerstown Official Series Description

C.2. Hagerstown \#1 Site and Profile Description

C.3. Hagerstown \#1 Characterization Data

C.4. Hagerstown \#2 Site and Profile Description

C.5. Hagerstown \#2 Characterization Data

C.6. Hagerstown \#3 Site and Profile Description

C.7. Hagerstown \#3 Characterization Data 


\section{C.1. Hagerstown Official Series Description}

LOCATION HAGERSTOWN

MD+IN KY PA TN VA WV

Established Series

Rev. JSK-MAV-ART

$06 / 2006$

\section{HAGERSTOWN SERIES}

The Hagerstown series consists of deep and very deep, well drained soils formed in residuum of hard gray limestone. Slope ranges from 0 to 45 percent. Permeability is moderate. Mean annual precipitation is 30 to 45 inches. Mean annual air temperature is 45 to 58 degrees.

TAXONOMIC CLASS: Fine, mixed, semiactive, mesic Typic Hapludalfs

TYPICAL PEDON: Hagerstown silt loam, on a 4 percent northwest slope in a small grain field. (Colors are for moist soil unless noted otherwise)

Ap1--0 to 7 inches; dark brown or brown (7.5YR 4/4) silt loam; moderate medium subangular blocky structure; friable; many fine and common medium roots; many fine and common medium tubular pores; neutral; abrupt smooth boundary.

Ap2--7 to 10 inches; dark brown or brown (7.5YR 4/4) silt loam; weak coarse platy structure; firm; many fine and few medium roots; common fine and medium tubular pores; 1 percent limestone channers; neutral; abrupt smooth boundary. (combined thickness of Ap horizons 6 to 12 inches)

BE--10 to 17 inches; strong brown (7.5YR 5/6) silt loam; common medium distinct dark brown or brown (7.5YR 4/2) organic stains in pores; moderate medium subangular blocky structure; friable; common fine and few medium roots; many fine and medium tubular and vesicular pores; few distinct clay films in pores; neutral; clear wavy boundary. (0 to 8 inches thick)

Bt1--17 to 26 inches; yellowish red (5YR 4/6) silty clay loam; common medium distinct very dark gray (5YR 3/1) iron manganese stains on faces and interiors of peds; common fine distinct very dark gray (5YR 3/1) iron manganese concretions; many medium dark brown or brown (7.5YR 4/3) organic stains in pores; moderate medium subangular blocky structure; friable; common fine roots; many fine and medium vesicular and tubular pores; many distinct clay films on ped faces and in pores; 2 percent limestone channers; slightly acid; clear wavy boundary.

Bt2--26 to 45 inches; reddish brown (2.5YR 4/4) silty clay; many fine and medium distinct very dark gray (5YR 3/1) iron manganese stains; common fine distinct very dark gray (5YR 3/1) iron manganese concretions; common medium distinct dark brown or brown $(7.5 \mathrm{YR} 4 / 3)$ organic stains in pores; strong fine subangular blocky structure; 
friable; common fine roots; many fine and medium vesicular and tubular pores; many prominent clay films on ped faces and in pores; 3 percent limestone channers; slightly acid; gradual wavy boundary.

Bt3--45 to 63 inches; red (2.5YR 4/6) clay; common medium distinct brownish yellow (10YR 6/8) lithochromic mottles; many medium distinct very dark gray (5YR 3/1) iron manganese stains; strong fine platy structure; friable; common fine and few medium roots; many fine and medium vesicular and tubular pores; common prominent clay films on ped faces and in pores; 5 percent limestone channers; neutral; gradual wavy boundary. (combined thickness of Bt horizons 20 to 50 inches)

BCt--63 to 71 inches; yellowish red (5YR 4/6), dark brown or brown (7.5YR 4/3) variegated silty clay loam; many medium prominent yellowish brown (10YR 5/8) lithochromic mottles; weak medium subangular blocky structure; friable; common fine roots; common fine and few medium vesicular and tubular pores; common distinct clay films on ped faces; 10 percent limestone channers; slightly acid.

TYPE LOCATION: Washington County, Maryland; north 2,300 feet of the intersection of Wheeler Road and Maryland Route 34, east 1,200 feet, Keedysville area. Funkstown USGS topographic quadrangle Lat. 39 degrees 30 minutes 03 seconds North and Long. 77 degrees 41 minutes 13 seconds West. NAD 83

RANGE IN CHARACTERISTICS: Solum thickness ranges from 40 to 72 inches, however, clay content decreases by more than 20 percent if deeper than 60 inches. Depth to hard limestone ranges from 40 to 84 inches or more. In limed soils, the upper part of the solum ranges from slightly acid through slightly alkaline and the lower part of the solum and substratum ranges from moderately acid through neutral. Hagerstown soils are low in rock fragments with less than 15 percent by volume. The weighted average clay content of the textural control section is between 35 and 60 percent.

The A or Ap horizon has hue of $10 \mathrm{YR}, 7.5 \mathrm{YR}$, or $5 \mathrm{YR}$, value of 3 to 5, and chroma of 2 to 4 . Texture is silt loam, loam, clay loam, and silty clay loam.

The BE horizon has hue of 7.5YR or $5 \mathrm{YR}$, value of 4 or 5 , and chroma of 4 to 8 . Texture is loam or silt loam.

The Bt horizon has hue of 5YR or 2.5YR, value of 4 or 5 , and chroma of 4 to 8 . Subhorizons of some pedons are 7.5YR. Texture is silty clay, clay, or silty clay loam.

The $\mathrm{BC}$ or BCt horizon has hue of $7.5 \mathrm{YR}$ to $2.5 \mathrm{YR}$, value of 4 or 5 , and chroma of 4 to 8 ; it ranges from being uniform in color to moderately variegated. Texture is silty clay, clay, clay loam, or silty clay loam.

The $\mathrm{C}$ horizon if present has hue of $10 \mathrm{YR}$ to $2.5 \mathrm{YR}$, value of 4 to 6 , and chroma of 4 to 8 ; it ranges from being uniform in color to moderately or highly variegated. Texture 
ranges from silt loam, loam, clay loam, silty clay loam to clay. In many pedons the C horizon is absent or is a very thin transition horizon between solum and bedrock.

COMPETING SERIES: In the same family is the Bland series. The Bland soils have sola less than 40 inches thick and are less than 40 inches to bedrock.

GEOGRAPHIC SETTING: Hagerstown soils occupy valley floors and the adjacent hills. In some areas rock outcrops are common surface features. Most slopes are less than 15 percent but range up to 45 percent. The soils developed in materials weathered from hard gray limestone of rather high purity. The climate is temperate and moderately humid, with a mean annual temperature of 45 to 58 degrees $F$. and mean annual precipitation of 30 to 45 inches.

GEOGRAPHICALLY ASSOCIATED SOILS: These are the Athol, Baltimore, Benevola, Clarksburg, Duffield, Dunmore, Edom, Elliber, Elk, Frankstown, Frederick, Conestoga, Murrill, and Opequon soils. Athol, Baltimore, Conestoga, Duffield, Elk, Frankstown, Murrill and Wiltshire soils have less than 35 percent clay in the textural control section. Baltimore and Benevola soils have an Ap horizon with a value of less than 3.5. Clarksburg, Dunmore and Frederick soils have a Bt horizon 50 to 75 inches thick that is dominantly kaolinitic in mineralogy. Edom soils have sola less than 40 inches thick. Opequon soils are less than 20 inches to bedrock.

DRAINAGE AND PERMEABILITY: Well drained. The potential for surface runoff is moderate to high. Permeability is moderate.

USE AND VEGETATION: General crops, pastures, orchards, and truck crops. Large areas are in non-farm uses. Native vegetation is mixed hardwoods, including black walnut.

DISTRIBUTION AND EXTENT: Pennsylvania, Maryland, Virginia, West Virginia, Kentucky and Tennessee; possibly Ohio, Indiana, and Missouri. The series is of large extent.

MLRA OFFICE RESPONSIBLE: Morgantown, West Virginia

SERIES ESTABLISHED: Lancaster County, Pennsylvania.

REMARKS: Previously revised by EDM-BLM-JEW in 10/98. New type location processed in 12/2003. (Decision to do this was made in 1997 ago. Sample reference number S92MD043-013

National Cooperative Soil Survey

U.S.A. 


\section{C.2. Hagerstown \#1 Site and Profile Description}

Sampled as: Hagerstown

Lab \#: S99-WV-003-001 -- Hagerstown \#1

Location: Glen Welch Farm - Berkeley County

Latitude: $39^{\circ} 28^{\prime} 41^{\prime \prime} \mathrm{N}$; Longitude: $77^{\circ} 52^{\prime} 56^{\prime \prime} \mathrm{W}$

Physiography: Valley and Ridge Province

Slope: $5 \%$

Elevation: $139.8 \mathrm{~m} \pm 10 \mathrm{~m}(460 \mathrm{ft} . \pm 33 \mathrm{ft}$. $)$

Land Use and Vegetation: Hayfield

Parent Material: Residual - Beekmantown Limestone

Described by: John Sencindiver, Brian Cooley, and James Bell on June 15, 1999

Ap - 0 to $17 \mathrm{~cm}$ (0 to 6.5 inches); dark brown (10YR 4/3) silt loam; weak medium subangular blocky structure parting to moderate fine granular; friable; many very fine and fine roots; 2 percent gravels; abrupt smooth boundary.

$\mathrm{BE}-17$ to $25 \mathrm{~cm}$ (6.5 to 10 inches); strong brown (7.5YR 5/6) silt loam; weak medium subangular blocky structure; friable; common very fine and fine roots; 2 percent channers; clear wavy boundary.

Bt1 - 25 to $42 \mathrm{~cm}$ (10 to 16.5 inches); strong brown (7.5YR 4/6) silty clay loam; moderate fine and medium subangular blocky structure; friable; common very fine and fine roots; few black manganese coatings on ped faces; common discontinuous distinct clay films; 5 percent siltstone channers; clear wavy boundary.

Bt2 - 42 to $77 \mathrm{~cm}$ (16.5 to 30.5 inches); yellowish red (5YR 4/6) clay; moderate medium subangular blocky structure; friable; few very fine and fine roots; few black manganese coatings on ped faces; many continuous prominent clay films; 5 percent siltstone channers; clear irregular boundary.

Bt3 - 77 to $94 \mathrm{~cm}$ (30.5 to 37 inches); yellowish red (5YR 4/6) silty clay loam; common medium yellowish brown (10YR 5/6) lithochromic mottles; moderate medium subangular blocky structure; friable; very few very fine and fine roots; few black manganese coatings on ped faces; many continuous prominent clay films; 2 percent siltstone channers; clear irregular boundary.

Bt4 - 94 to $118 \mathrm{~cm}$ (37 to 46.5 inches); strong brown (7.5YR 4/6) silt loam; common medium yellowish red (5YR 4/6) and many medium yellowish brown (10YR 5/6) mottles; weak medium subangular blocky structure; friable; very few very fine to medium roots; common discontinuous distinct clay films; 5 percent siltstone channers; clear irregular boundary. 
$\mathrm{BC}-118$ to $145 \mathrm{~cm}$ (46.5 to 57 inches); mixed yellowish brown (10YR 5/6), strong brown (7.5YR 4/6) and yellowish red (5YR 4/6) silt loam; weak medium subangular blocky structure; friable; very few fine to coarse roots; few patchy distinct yellowish red (5YR 4/6) clay films; 10 percent siltstone channers; clear wavy boundary.

$\mathrm{C}-145$ to $160+\mathrm{cm}$ (57 to $63+$ inches); strong brown (7.5YR 4/6) silt loam; many medium and coarse yellowish brown (10YR 5/6) and few medium yellowish red (5YR 4/6) mottles; massive; friable; very few fine to coarse roots; common black manganese coatings on ped faces and rock fragments; 10 percent siltstone channers. 


\section{C.3. Hagerstown \#1 Characterization Data}

\begin{tabular}{|c|c|c|c|c|c|c|c|c|c|}
\hline \multirow{3}{*}{ Horizon } & \multirow{3}{*}{ Depth } & \multicolumn{8}{|c|}{ Particle Size } \\
\hline & & \multicolumn{3}{|c|}{ Total } & \multicolumn{5}{|c|}{ Sand } \\
\hline & & Sand & Silt & Clay & V. Coarse & Coarse & Medium & Fine & V. Fine \\
\hline & $\mathrm{cm}$ & & & & $---\%$ & & & & -- \\
\hline Ap & $0-17$ & 20.0 & 60.3 & 19.7 & 3.7 & 2.9 & 1.8 & 2.0 & 9.6 \\
\hline $\mathrm{BE}$ & $17-25$ & 16.7 & 59.3 & 24.0 & 1.6 & 2.0 & 1.6 & 1.5 & 10.0 \\
\hline Bt1 & $25-42$ & 20.9 & 46.2 & 32.9 & $\overline{0.6}$ & 1.9 & 1.7 & 2.7 & 14.0 \\
\hline Bt2 & $42-77$ & 19.7 & 30.5 & 49.8 & 0.6 & 1.9 & 1.4 & 2.1 & 13.7 \\
\hline $\mathrm{Bt3}$ & $77-94$ & 30.3 & 22.4 & 47.3 & 0.4 & 1.0 & 0.9 & 4.3 & 23.7 \\
\hline Bt4 & $94-118$ & 26.8 & 31.3 & 41.9 & 2.2 & 2.9 & 1.9 & 3.3 & 16.5 \\
\hline$B C$ & $118-145$ & 26.0 & 29.5 & 44.5 & 0.7 & 0.9 & 1.2 & 4.3 & 18.9 \\
\hline $\mathrm{C}$ & $145-160+$ & 27.3 & 36.3 & 36.4 & 0.6 & 1.7 & 1.8 & 3.1 & 20.1 \\
\hline
\end{tabular}

\begin{tabular}{|c|c|c|c|c|c|c|c|}
\hline \multirow{3}{*}{ Horizon } & \multirow{3}{*}{ Depth } & \multicolumn{4}{|c|}{ Bulk Density } & \multirow{2}{*}{\multicolumn{2}{|c|}{ Atterberg Limits }} \\
\hline & & \multicolumn{2}{|c|}{ Oven-Dry } & \multicolumn{2}{|c|}{33 kPA Desorption } & & \\
\hline & & $\mathrm{Db}>2 \mathrm{~mm}$ & $\mathrm{Db}<2 \mathrm{~mm}$ & $\mathrm{Db}>2 \mathrm{~mm}$ & $\mathrm{Db}<2 \mathrm{~mm}$ & Liquid Limit & Plasticity Index \\
\hline & $\mathrm{cm}$ & & $--\mathrm{g}$ & 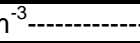 & - & & \\
\hline $\mathrm{Ap}$ & $0-17$ & 1.64 & 1.58 & 1.62 & 1.56 & 31 & 9 \\
\hline $\mathrm{BE}$ & $17-25$ & 1.70 & 1.67 & 1.68 & 1.65 & 30 & 12 \\
\hline Bt1 & $25-42$ & 1.69 & 1.62 & 1.67 & 1.60 & 34 & 18 \\
\hline Bt2 & $42-77$ & 1.57 & 1.44 & 1.52 & 1.40 & 51 & 32 \\
\hline Bt3 & $77-94$ & 1.61 & 1.57 & 1.57 & 1.52 & 50 & 31 \\
\hline Bt4 & $94-118$ & $\overline{--}$ & $\overline{--}$ & $\overline{--}$ & $\overline{--}$ & 48 & 29 \\
\hline $\mathrm{BC}$ & $118-145$ & 1.55 & 1.46 & 1.52 & 1.43 & 49 & 29 \\
\hline $\mathrm{C}$ & $145-160+$ & 1.47 & 1.40 & 1.42 & 1.35 & 44 & 24 \\
\hline
\end{tabular}

\begin{tabular}{|c|c|c|c|c|c|c|}
\hline \multirow{2}{*}{ Horizon } & \multirow{2}{*}{ Depth } & \multirow{2}{*}{\begin{tabular}{|c|} 
Rock \\
Fragments by \\
Wt.
\end{tabular}} & \multicolumn{3}{|c|}{ Water Retention } & \multirow{2}{*}{ COLE } \\
\hline & & & $33 \mathrm{kPA}$ & $1500 \mathrm{kPA}$ & \multirow{2}{*}{$\frac{\text { WRD }}{\mathrm{cm} \mathrm{cm}^{-1}}$} & \\
\hline & $\mathrm{cm}$ & 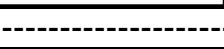 & ---\%---- & 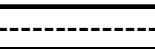 & & \\
\hline$A p$ & $0-17$ & 8.2 & 29.4 & 8.6 & 0.32 & 0.00 \\
\hline $\mathrm{BE}$ & $17-25$ & 5.7 & 26.6 & 10.0 & 0.27 & 0.01 \\
\hline Bt1 & $25-42$ & 8.5 & 29.2 & 12.7 & 0.25 & 0.01 \\
\hline $\mathrm{Bt2}$ & $42-77$ & 4.0 & 37.1 & 18.9 & 0.24 & 0.01 \\
\hline $\mathrm{Bt3}$ & $77-94$ & 6.5 & 37.8 & 18.6 & 0.29 & 0.01 \\
\hline Bt4 & $94-118$ & 8.6 & 39.5 & 17.4 & -- & -- \\
\hline$B C$ & 118-145 & 12.7 & 36.8 & 18.1 & 0.24 & 0.02 \\
\hline C & $145-160+$ & 9.9 & 39.3 & 15.4 & 0.29 & 0.02 \\
\hline
\end{tabular}




\begin{tabular}{|c|c|c|c|c|c|c|c|c|c|c|c|c|}
\hline \multirow{2}{*}{ Horizon } & \multirow{2}{*}{ Depth } & \multicolumn{6}{|c|}{ Extractable } & \multicolumn{2}{|c|}{ CEC } & \multirow{2}{*}{ ECEC } & \multicolumn{2}{|c|}{ Base Saturation } \\
\hline & & $\mathrm{Ca}$ & $\mathrm{Mg}$ & $\mathrm{Na}$ & $\bar{K}$ & Acidity & $\mathrm{Al}$ & CEC-8.2 & CEC-7 & & CEC-8.2 & CEC-7 \\
\hline & $\mathrm{cm}$ & \multicolumn{9}{|c|}{ 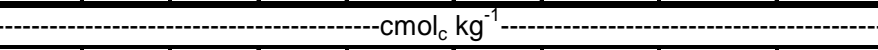 } & \multicolumn{2}{|c|}{ 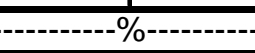 } \\
\hline Ap & $0-17$ & 5.8 & 0.6 & 0.3 & 0.4 & 6.3 & -- & 13.4 & 8.7 & -- & 53.0 & 81.6 \\
\hline $\mathrm{BE}$ & $17-25$ & 5.6 & 0.5 & 0.3 & 0.4 & 3.7 & -- & 10.5 & 7.2 & -- & 64.8 & 94.4 \\
\hline Bt1 & $25-42$ & 6.8 & 0.8 & 0.3 & 0.3 & 3.8 & -- & 12.0 & 8.5 & 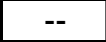 & 68.3 & 96.5 \\
\hline Bt2 & $42-77$ & 6.2 & 1.7 & 0.2 & $\overline{0.3}$ & 8.8 & -- & 17.2 & 11.6 & -- & 48.8 & 72.4 \\
\hline Bt3 & $77-94$ & 2.3 & 1.9 & 0.2 & $\mathrm{BDL}$ & 12.7 & 6.2 & 17.1 & 11.7 & 10.6 & 25.7 & 37.6 \\
\hline Bt4 & $94-118$ & 2.6 & 2.8 & 0.2 & 0.3 & 13.1 & 7.8 & 19.0 & 14.9 & 13.7 & 31.1 & 39.6 \\
\hline$B C$ & \begin{tabular}{|l|}
$118-145$ \\
\end{tabular} & 1.9 & 2.7 & 0.2 & 0.1 & 14.6 & 9.5 & 19.5 & 15.5 & 14.4 & 25.1 & 31.6 \\
\hline $\mathrm{C}$ & $145-160+$ & 1.2 & 2.2 & 0.2 & $\mathrm{BDL}$ & 12.8 & 8.2 & 16.4 & 12.7 & 11.8 & 22.0 & 28.3 \\
\hline
\end{tabular}

\begin{tabular}{|c|c|c|c|c|c|c|c|c|}
\hline \multirow{2}{*}{ Horizon } & \multirow{2}{*}{ Depth } & \multirow{2}{*}{ Al Saturation } & \multicolumn{3}{|c|}{ Total } & \multirow{2}{*}{$\begin{array}{c}\text { Extractable } \\
\text { Mn }\end{array}$} & \multicolumn{2}{|c|}{$\mathrm{pH}$} \\
\hline & & & Carbon & Sulfur & Nitrogen & & 1:1 Water & $1: 2 \mathrm{CaCl}_{2}$ \\
\hline & $\mathrm{cm}$ & & $---\%$ & & & $\mathrm{mg} \mathrm{kg}^{-1}$ & & \\
\hline$A p$ & $0-17$ & -- & 1.30 & 0.02 & 0.14 & -- & 6.0 & 5.4 \\
\hline $\mathrm{BE}$ & $17-25$ & -- & 0.44 & 0.01 & 0.06 & -- & 6.2 & 5.6 \\
\hline Bt1 & $25-42$ & $\overline{--}$ & 0.28 & 0.01 & 0.04 & $\overline{--}$ & 6.4 & 5.6 \\
\hline Bt2 & $42-77$ & $\overline{--}$ & 0.17 & 0.02 & 0.03 & -- & 5.5 & 5.3 \\
\hline $\mathrm{Bt3}$ & $77-94$ & 58.5 & 0.12 & 0.01 & 0.04 & 0.90 & 4.9 & 4.1 \\
\hline Bt4 & $94-118$ & 56.9 & 0.13 & 0.01 & 0.05 & BDL & 4.8 & 4.6 \\
\hline$B C$ & $118-145$ & 66.0 & 0.14 & 0.01 & 0.06 & 0.30 & 4.9 & 4.0 \\
\hline $\mathrm{C}$ & $145-160+$ & 69.5 & 0.12 & 0.01 & 0.04 & 2.10 & 4.7 & 4.5 \\
\hline
\end{tabular}

\begin{tabular}{|c|c|c|c|c|c|c|c|c|}
\hline \multirow{2}{*}{ Horizon } & \multirow{2}{*}{ Depth } & \multicolumn{7}{|c|}{ Total Elemental Analysis } \\
\hline & & $\mathrm{Fe}$ & $\mathrm{Mn}$ & Al & $\mathrm{Ca}$ & $\mathrm{Mg}$ & $\mathrm{Na}$ & K \\
\hline & $\mathrm{cm}$ & & & & $\mathrm{ng} \mathrm{kg}^{-1}$ & & & \\
\hline$A p$ & $0-17$ & 20251.5 & 733.3 & 28510.3 & 1469.4 & 1654.9 & 1798.5 & 3068.4 \\
\hline $\mathrm{BE}$ & $17-25$ & 20204.3 & 139.2 & 33418.3 & 1088.0 & 1896.0 & 1568.8 & 1451.8 \\
\hline Bt1 & $25-42$ & 24470.3 & 81.3 & 38498.3 & 1231.1 & 2296.6 & 1162.5 & 3801.5 \\
\hline Bt2 & $42-77$ & 35518.8 & 104.1 & 39504.8 & 1010.4 & 2576.6 & 741.9 & 3483.0 \\
\hline $\mathrm{Bt3}$ & $77-94$ & 31669.5 & 124.1 & 42373.2 & 561.8 & 1887.1 & 679.1 & 3619.9 \\
\hline Bt4 & $94-118$ & 34847.2 & 130.8 & 49376.9 & 533.8 & 3077.2 & 616.2 & 3980.8 \\
\hline $\mathrm{BC}$ & $118-145$ & 33657.8 & 129.8 & 42648.8 & 380.1 & 2735.6 & 629.3 & 3202.5 \\
\hline$C$ & $145-160+$ & 33546.3 & 311.6 & 42055.8 & 422.3 & 2459.3 & 665.8 & 3676.0 \\
\hline
\end{tabular}

\begin{tabular}{|c|c|c|c|c|c|c|c|c|}
\hline \multirow{2}{*}{ Horizon } & \multirow{2}{*}{ Depth } & \multicolumn{7}{|c|}{ Total Elemental Analysis } \\
\hline & & $P$ & $\mathrm{Si}$ & $\mathrm{Cu}$ & $\mathrm{Zn}$ & $\mathrm{Ni}$ & As & Co \\
\hline & $\mathrm{cm}$ & & & & $-\mathrm{mg} \mathrm{kg}$ & & & \\
\hline$A p$ & $0-17$ & 594.2 & 107543.1 & 28.8 & 61.9 & 15.0 & 8.4 & 68.0 \\
\hline $\mathrm{BE}$ & $17-25$ & 269.2 & 102166.6 & 31.7 & 259.6 & 19.9 & 8.1 & 59.8 \\
\hline Bt1 & $25-42$ & 303.4 & 120937.2 & 36.1 & 84.1 & 24.0 & 10.9 & 75.4 \\
\hline Bt2 & $42-77$ & 470.9 & 125780.6 & 47.0 & 203.8 & 44.1 & 9.8 & 92.7 \\
\hline $\mathrm{Bt3}$ & $77-94$ & 464.3 & 126955.9 & 49.1 & 220.8 & 39.1 & 12.5 & 86.8 \\
\hline Bt4 & $94-118$ & 318.0 & 127213.6 & 51.8 & 503.0 & 35.8 & 11.4 & 91.1 \\
\hline $\mathrm{BC}$ & $118-145$ & 321.2 & 129310.4 & 47.1 & 407.3 & 38.0 & 10.5 & 88.4 \\
\hline $\mathrm{C}$ & 145-160+ & 378.2 & 124260.9 & 45.8 & 135.6 & 35.9 & 15.8 & 87.0 \\
\hline
\end{tabular}




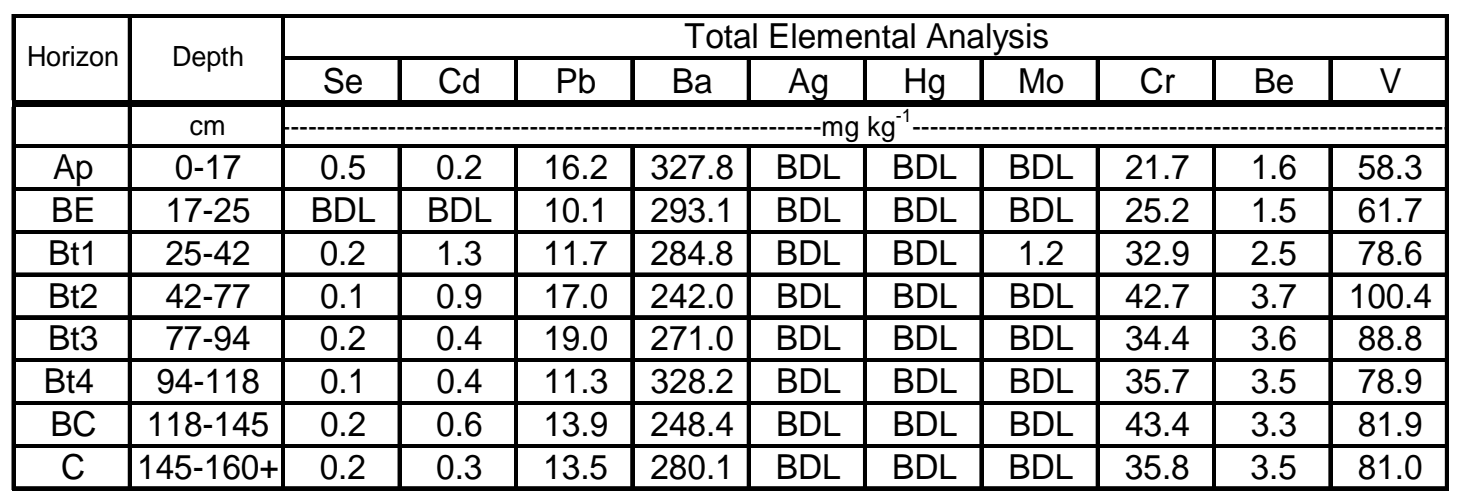

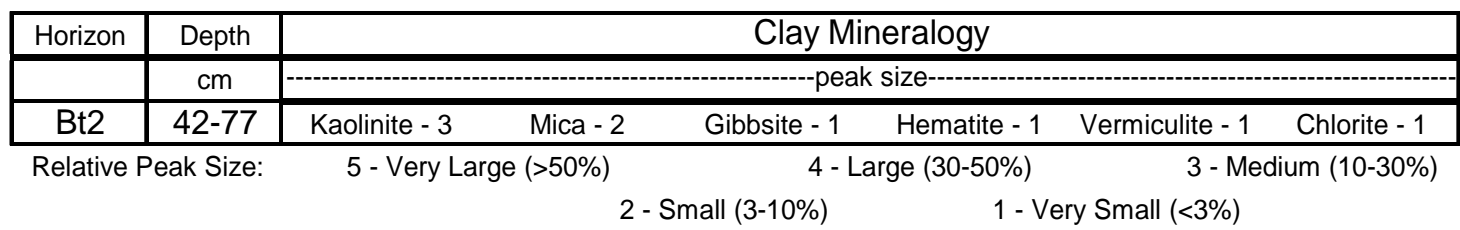




\section{C.4. Hagerstown \#2 Site and Profile Description}

Sampled as: Hagerstown

Lab \#: S99-WV-037-001 -- Hagerstown \#2

Location: Leetown Fisheries Center - Jefferson County

Latitude: $39^{\circ} 21^{\prime} 15^{\prime \prime} \mathrm{N}$; Longitude: $77^{\circ} 55^{\prime} 01^{\prime \prime} \mathrm{W}$

Physiography: Valley and Ridge Province

Elevation: $162 \mathrm{~m} \pm 8.5 \mathrm{~m}(533 \mathrm{ft} . \pm 28 \mathrm{ft}$. $)$

Land Use and Vegetation: Abandoned agricultural field with tall fescue and black locust.

Parent Material: Residual - Beekmantown Limestone

Described by: John Sencindiver and Bill Bates on June 16, 1999.

A -0 to $9 \mathrm{~cm}$ (0 to 3.5 inches); brown (10YR 4/3) silt loam; moderate fine granular structure; very friable; many very fine and fine roots; abrupt smooth boundary.

E - 9 to $20 \mathrm{~cm}$ (3.5 to 8 inches); yellowish brown (10YR 5/4) silt loam; weak fine and medium subangular blocky structure; friable; many very fine and fine roots; abrupt smooth boundary.

$\mathrm{BE}-20$ to $32 \mathrm{~cm}$ ( 8 to 12.5 inches); strong brown (7.5YR 5/8) silt loam; common medium yellowish red (5YR 4/6) mottles; moderate medium subangular blocky structure; hard (dry); firm (moist); common very fine and fine roots; common old root channels filled with materials from above; clear wavy boundary.

Bt1 -32 to $59 \mathrm{~cm}$ (12.5 to 23 inches); yellowish red (5YR 4/6) silty clay; strong medium angular blocky structure; very hard (dry); firm (moist); common very fine and fine roots; few medium black manganese coatings on ped faces; many continuous distinct clay films; 2 percent chert channers; gradual wavy boundary.

Bt2 - 59 to $91 \mathrm{~cm}$ (23 to 36 inches); yellowish red (5YR 4/6) clay; moderate fine and medium subangular blocky structure; firm; few very fine roots; common medium and coarse black manganese coatings on ped faces; many continuous prominent clay films; 2 percent chert channers; gradual wavy boundary.

Bt3 - 91 to $132 \mathrm{~cm}$ (36 to 52 inches); yellowish red (5YR 4/6) silty clay with pockets of clay loam; common medium and coarse strong brown (7.5YR 5/8) mottles; moderate medium subangular blocky structure; friable; very few very fine roots; many medium black manganese coatings on ped faces; common discontinuous distinct clay films; 2 percent sandstone channers; gradual wavy boundary.

$\mathrm{BC}-132$ to $171 \mathrm{~cm}$ (52 to 67.5 inches); strong brown (7.5YR 5/8) silty clay loam; common medium and coarse yellowish red (5YR 4/6) mottles; weak medium subangular blocky structure; friable; few patchy faint clay films; many medium black manganese coatings on ped faces; gradual wavy boundary. 
C/B -171 to $201+\mathrm{cm}$ ( 67.5 to $79+$ inches); strong brown (7.5YR 5/8) silty clay loam; common medium and coarse yellowish red (5YR 4/6) mottles; massive and weak medium subangular blocky structure; friable; many medium black manganese coatings on ped faces; very few patchy distinct clay films. 


\section{C.5. Hagerstown \#2 Characterization Data}

\begin{tabular}{|c|c|c|c|c|c|c|c|c|c|}
\hline \multirow{3}{*}{ Horizon } & \multirow{3}{*}{ Depth } & \multicolumn{8}{|c|}{ Particle Size } \\
\hline & & \multicolumn{3}{|c|}{ Total } & \multicolumn{5}{|c|}{ Sand } \\
\hline & & Sand & Silt & Clay & V. Coarse & Coarse & Medium & Fine & V. Fine \\
\hline & $\mathrm{cm}$ & --.- & & & $----\%-$ & -- & 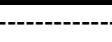 & 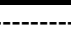 & ---- \\
\hline A & $0-9$ & 8.7 & 73.6 & 17.7 & 0.1 & 0.7 & 0.9 & 1.5 & 5.5 \\
\hline$E$ & $9-20$ & 9.9 & 72.1 & 18.0 & 0.2 & 0.6 & 1.1 & 1.7 & 6.3 \\
\hline $\mathrm{BE}$ & $20-32$ & 9.3 & 64.3 & 26.4 & 0.3 & 0.5 & 1.1 & 1.4 & 6.0 \\
\hline Bt1 & $32-59$ & 7.9 & 47.4 & 44.7 & 0.3 & 0.4 & 0.8 & 1.4 & 5.0 \\
\hline Bt2 & $59-91$ & 5.2 & 36.1 & 58.7 & $\overline{0.4}$ & 0.3 & 0.4 & 0.8 & 3.3 \\
\hline Bt3 & $91-132$ & 7.8 & 37.8 & 54.4 & 0.1 & 0.3 & 0.6 & 1.3 & 5.5 \\
\hline $\mathrm{BC}$ & $132-171$ & 9.1 & 41.8 & 49.1 & 0.3 & 0.4 & 0.6 & 1.3 & 6.5 \\
\hline $\mathrm{C} / \mathrm{B}$ & 171-201+ & 9.3 & 44.6 & 46.1 & 0.3 & 0.5 & 0.9 & 1.4 & 6.2 \\
\hline
\end{tabular}

\begin{tabular}{|c|c|c|c|c|c|c|c|}
\hline \multirow{3}{*}{ Horizon } & \multirow{3}{*}{ Depth } & \multicolumn{4}{|c|}{ Bulk Density } & \multirow{2}{*}{\multicolumn{2}{|c|}{ Atterberg Limits }} \\
\hline & & \multicolumn{2}{|c|}{ Oven-Dry } & \multicolumn{2}{|c|}{33 kPA Desorption } & & \\
\hline & & $\mathrm{Db}>2 \mathrm{~mm}$ & $\mathrm{Db}<2 \mathrm{~mm}$ & $\mathrm{Db}>2 \mathrm{~mm}$ & $\mathrm{Db}<2 \mathrm{~mm}$ & Liquid Limit & Plasticity Index \\
\hline & $\mathrm{cm}$ & & $---\mathrm{g}$ & $n^{-3}-\cdots-$ & ----' & & \\
\hline $\bar{A}$ & $0-9$ & $\overline{--}$ & -- & $\overline{--}$ & $\overline{--}$ & 49 & 19 \\
\hline $\mathrm{E}$ & $9-20$ & $\overline{--}$ & -- & -- & -- & 32 & 11 \\
\hline $\mathrm{BE}$ & $20-32$ & 1.68 & 1.67 & 1.64 & 1.64 & 29 & 11 \\
\hline Bt1 & $32-59$ & 1.72 & 1.70 & 1.63 & 1.60 & 47 & 33 \\
\hline Bt2 & $59-91$ & 1.70 & 1.69 & 1.57 & 1.56 & 60 & 42 \\
\hline $\mathrm{Bt3}$ & $91-132$ & 1.70 & 1.68 & 1.58 & 1.57 & 59 & 42 \\
\hline $\mathrm{BC}$ & $132-171$ & 1.69 & 1.69 & 1.59 & 1.59 & 55 & 39 \\
\hline $\mathrm{C} / \mathrm{B}$ & $171-201+$ & $\overline{--}$ & $\overline{--}$ & $\overline{--}$ & $\overline{--}$ & 49 & 34 \\
\hline
\end{tabular}

\begin{tabular}{|c|c|c|c|c|c|c|}
\hline \multirow{2}{*}{ Horizon } & \multirow{2}{*}{ Depth } & \multirow{2}{*}{\begin{tabular}{|c|} 
Rock \\
Fragments by \\
Wt.
\end{tabular}} & \multicolumn{3}{|c|}{ Water Retention } & \multirow{2}{*}{ COLE } \\
\hline & & & $33 \mathrm{kPA}$ & $1500 \mathrm{kPA}$ & \multirow{2}{*}{$\frac{\text { WRD }}{\mathrm{cm} \mathrm{cm}^{-1}}$} & \\
\hline & $\mathrm{cm}$ & & ---\%--- & ---------- & & \\
\hline $\bar{A}$ & $0-9$ & 0.6 & 39.2 & 9.4 & -- & $\overline{--}$ \\
\hline$E$ & $9-20$ & 2.1 & 32.5 & 6.8 & -- & -- \\
\hline $\mathrm{BE}$ & $20-32$ & 1.5 & 27.7 & 9.7 & 0.30 & 0.01 \\
\hline Bt1 & $32-59$ & 0.5 & 30.1 & 16.5 & 0.21 & 0.02 \\
\hline Bt2 & $59-91$ & 0.7 & 37.7 & 21.2 & 0.25 & 0.03 \\
\hline Bt3 & 91-132 & 1.0 & 40.9 & 20.2 & 0.32 & 0.02 \\
\hline $\mathrm{BC}$ & $132-171$ & 1.1 & 35.0 & 18.5 & 0.26 & 0.02 \\
\hline $\mathrm{C} / \mathrm{B}$ & 171-201+ & 1.4 & 34.9 & 17.5 & $\overline{--}$ & -- \\
\hline
\end{tabular}




\begin{tabular}{|c|c|c|c|c|c|c|c|c|c|c|c|c|}
\hline \multirow{2}{*}{ Horizon } & \multirow{2}{*}{ Depth } & \multicolumn{6}{|c|}{ Extractable } & \multicolumn{2}{|c|}{ CEC } & \multirow{2}{*}{ ECEC } & \multicolumn{2}{|c|}{ Base Saturation } \\
\hline & & $\mathrm{Ca}$ & $\mathrm{Mg}$ & $\mathrm{Na}$ & $\mathrm{K}$ & Acidity & $\mathrm{Al}$ & CEC-8.2 & CEC-7 & & CEC-8.2 & CEC-7 \\
\hline & $\mathrm{cm}$ & \multicolumn{9}{|c|}{ - $\mathrm{cmol}_{\mathrm{c}} \mathrm{kg}^{-1}$} & \multicolumn{2}{|c|}{ 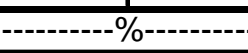 } \\
\hline A & $0-9$ & 9.5 & 3.4 & 0.2 & 0.7 & 5.5 & -- & 19.3 & 14.4 & -- & 71.5 & 95.8 \\
\hline$E$ & $9-20$ & 5.3 & 1.7 & 0.2 & 0.4 & 3.3 & -- & 10.9 & 8.1 & -- & 69.7 & 93.8 \\
\hline $\mathrm{BE}$ & $20-32$ & 5.0 & 1.6 & 0.3 & 0.3 & 2.8 & -- & 10.0 & 8.5 & -- & 72.0 & 84.7 \\
\hline Bt1 & $32-59$ & 7.3 & 1.8 & 0.2 & 0.3 & 4.7 & -- & 14.3 & 11.7 & -- & 67.1 & 82.1 \\
\hline Bt2 & $59-91$ & 6.8 & 2.7 & 0.3 & 0.6 & 9.4 & -- & 19.8 & 14.7 & -- & 52.5 & 70.7 \\
\hline $\mathrm{Bt3}$ & 91-132 & 7.8 & 3.4 & 0.3 & 0.3 & 6.2 & 0.3 & 18.0 & 14.5 & 12.1 & 65.6 & 81.4 \\
\hline $\mathrm{BC}$ & $132-171$ & 7.3 & 3.0 & 0.2 & 0.2 & 5.5 & $\mathrm{BDL}$ & 16.2 & 12.7 & 10.7 & 66.0 & 84.3 \\
\hline $\mathrm{C} / \mathrm{B}$ & 171-201+ & 7.3 & 3.0 & 0.3 & 0.3 & 5.0 & $\mathrm{BDL}$ & 15.9 & 12.2 & 10.9 & 68.6 & 89.3 \\
\hline
\end{tabular}

\begin{tabular}{|c|c|c|c|c|c|c|c|c|}
\hline \multirow{2}{*}{ Horizon } & \multirow{2}{*}{ Depth } & \multirow{2}{*}{ Al Saturation } & \multicolumn{3}{|c|}{ Total } & \multirow{2}{*}{$\begin{array}{c}\text { Extractable } \\
\text { Mn }\end{array}$} & \multicolumn{2}{|c|}{$\mathrm{pH}$} \\
\hline & & & Carbon & Sulfur & \begin{tabular}{|l|} 
Nitrogen \\
\end{tabular} & & 1:1 Water & $1: 2 \mathrm{CaCl}_{2}$ \\
\hline & $\mathrm{cm}$ & & $---\%$ & & & $\mathrm{mg} \mathrm{kg}^{-1}$ & & \\
\hline $\bar{A}$ & $0-9$ & $\overline{--}$ & 3.28 & 0.05 & 0.31 & -- & 5.7 & 5.8 \\
\hline$E$ & $9-20$ & -- & 1.24 & 0.03 & 0.15 & -- & 6.5 & 6.0 \\
\hline $\mathrm{BE}$ & $20-32$ & $\overline{--}$ & 0.51 & 0.04 & 0.08 & $\overline{--}$ & 6.6 & 6.0 \\
\hline Bt1 & $32-59$ & $\overline{--}$ & 0.33 & 0.02 & 0.04 & -- & 6.3 & 5.5 \\
\hline Bt2 & $59-91$ & $\overline{--}$ & 0.31 & 0.05 & 0.06 & $\overline{--}$ & 5.6 & 4.5 \\
\hline Bt3 & $91-132$ & 2.5 & 0.14 & 0.02 & 0.04 & 2.40 & 5.6 & 4.8 \\
\hline$B C$ & $132-171$ & BDL & 0.14 & 0.02 & 0.04 & 1.90 & 5.5 & 5.0 \\
\hline $\mathrm{C} / \mathrm{B}$ & 171-201+ & $\mathrm{BDL}$ & 0.13 & 0.02 & 0.04 & 1.30 & 5.8 & 5.1 \\
\hline
\end{tabular}

\begin{tabular}{|c|c|c|c|c|c|c|c|c|}
\hline \multirow{2}{*}{ Horizon } & \multirow{2}{*}{ Depth } & \multicolumn{7}{|c|}{ Total Elemental Analysis } \\
\hline & & $\mathrm{Fe}$ & $\mathrm{Mn}$ & Al & $\mathrm{Ca}$ & $\mathrm{Mg}$ & $\mathrm{Na}$ & K \\
\hline & $\mathrm{cm}$ & & & & $-\mathrm{mg} \mathrm{kg}^{-1}$ & & & \\
\hline$A$ & $0-9$ & 15296.1 & 704.4 & 36607.5 & 2702.9 & 2885.2 & 1692.6 & 3049.0 \\
\hline $\bar{E}$ & $9-20$ & 14846.6 & 596.5 & 36893.5 & 1637.5 & 2602.3 & 1706.2 & 3243.5 \\
\hline $\mathrm{BE}$ & $20-32$ & 24337.0 & 388.7 & 45872.3 & 1362.9 & 2052.2 & 1502.5 & 3100.7 \\
\hline Bt1 & $32-59$ & 34057.3 & 212.8 & 62691.4 & 1741.0 & 4615.3 & 943.8 & 2969.2 \\
\hline $\mathrm{Bt} 2$ & $59-91$ & 42924.2 & 268.5 & 72148.9 & 1849.0 & 5676.4 & 848.2 & 2715.8 \\
\hline $\mathrm{Bt3}$ & $91-132$ & 40257.0 & 489.1 & 73777.6 & 1591.9 & 5686.6 & 457.2 & 2708.1 \\
\hline $\mathrm{BC}$ & $132-171$ & 39088.6 & 410.8 & 67716.0 & 1414.8 & 5727.4 & 602.6 & 3155.9 \\
\hline $\mathrm{C} / \mathrm{B}$ & 171-201+ & 40803.5 & 479.2 & 63627.4 & 1345.2 & 5948.7 & 555.1 & 3058.4 \\
\hline
\end{tabular}

\begin{tabular}{|c|c|c|c|c|c|c|c|c|}
\hline \multirow{2}{*}{ Horizon } & \multirow{2}{*}{ Depth } & \multicolumn{7}{|c|}{ Total Elemental Analysis } \\
\hline & & $\mathrm{P}$ & $\mathrm{Si}$ & $\mathrm{Cu}$ & $\mathrm{Zn}$ & $\mathrm{Ni}$ & As & Co \\
\hline & $\mathrm{cm}$ & & & & $\mathrm{mg} \mathrm{kg}^{-1}$ & & & \\
\hline $\bar{A}$ & $0-9$ & 555.2 & 126392.1 & 26.3 & 119.9 & 4.7 & 5.9 & 43.6 \\
\hline $\bar{E}$ & $9-20$ & 337.3 & 140967.3 & 25.8 & 92.3 & 6.9 & 5.6 & 45.6 \\
\hline $\mathrm{BE}$ & $20-32$ & 210.4 & 143125.8 & 32.1 & 95.5 & 13.1 & 8.0 & 66.1 \\
\hline Bt1 & $32-59$ & 278.2 & 142319.5 & 54.8 & 135.3 & 28.7 & 7.6 & 96.5 \\
\hline Bt2 & $59-91$ & 380.3 & 132786.9 & 69.0 & 147.7 & 44.8 & 5.5 & 116.8 \\
\hline $\mathrm{Bt3}$ & $91-132$ & 344.0 & 125372.5 & 61.5 & 171.7 & 50.0 & 7.7 & 109.4 \\
\hline $\mathrm{BC}$ & $132-171$ & 369.3 & 106922.9 & 63.5 & 172.9 & 39.5 & 8.7 & 107.1 \\
\hline $\mathrm{C} / \mathrm{B}$ & 171-201+ & 371.0 & 139705.7 & 55.5 & 195.8 & 38.7 & 8.4 & 95.4 \\
\hline
\end{tabular}




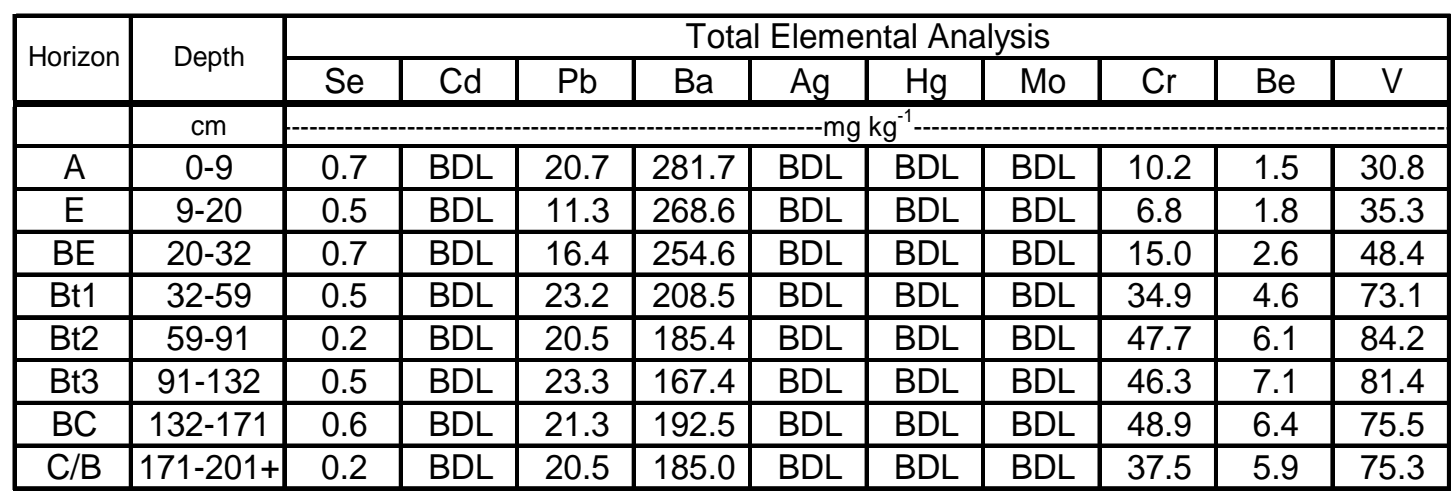

\begin{tabular}{|c|c|c|c|c|c|}
\hline Horizon & Depth & \multicolumn{4}{|c|}{ Clay Mineralogy } \\
\hline & $\mathrm{cm}$ & \multicolumn{4}{|c|}{ - } \\
\hline Bt2 & $59-91$ & Kaolinite - 3 Vermiculite - 2 & Montmorillonite - 2 & Geothite - 1 & Vermiculite-Mica - 1 \\
\hline Relative & k Size: & 5 - Very Large $(>50 \%)$ & \multicolumn{2}{|c|}{4 - Large (30-50\%) } & 3 - Medium (10-30\%) \\
\hline
\end{tabular}

$$
2 \text { - Small }(3-10 \%) \quad 1 \text { - Very Small }(<3 \%)
$$




\section{C.6. Hagerstown \#3 Site and Profile Description}

Sampled as: Hagerstown

Lab \#: S99-WV-037-002 -- Hagerstown \#3

Location: West Virginia University Kearneysville Farm - Jefferson County

Latitude: $39^{\circ} 23^{\prime} 51^{\prime \prime} \mathrm{N}$; Longitude: $77^{\circ} 53^{\prime} 30^{\prime \prime} \mathrm{W}$

Physiography: Valley and Ridge Province

Slope: $2-3 \%$

Elevation: $158.1 \mathrm{~m} \pm 7.9 \mathrm{~m}(520 \mathrm{ft} . \pm 26 \mathrm{ft}$.

Land Use and Vegetation: Orchard with grasses and weeds.

Parent Material: Residual - Beekmantown Limestone

Described by: John Sencindiver and Jason Knopp on June 17, 1999

Ap - 0 to $18 \mathrm{~cm}$ (0 to 7 inches); dark yellowish brown (10YR 4/4) silt loam; weak medium subangular blocky structure parting to weak medium granular; friable; many very fine to medium roots; 2 percent chert channers; abrupt smooth boundary.

$\mathrm{BE}-18$ to $32 \mathrm{~cm}$ (7 to 12.5 inches); strong brown (7.5YR 4/6) silty clay loam; moderate fine and medium subangular blocky structure; friable; common very fine to medium roots; few patchy faint clay films; 2 percent chert channers; clear wavy boundary.

Bt1 - 32 to $52 \mathrm{~cm}$ (12.5 to 20.5 inches); reddish brown (5YR 4/4) clay; strong fine and medium subangular blocky structure; firm; common very fine to medium roots; few fine and medium black manganese coatings; many continuous prominent clay films; 10 percent fine, soft yellow (10YR 7/8) siltstone fragments; 1 percent chert channers; clear wavy boundary.

Bt2 - 52 to $93 \mathrm{~cm}$ (20.5 to 36.5 inches); reddish brown (5YR 4/4) clay; weak medium prismatic structure parting to strong medium subangular blocky; firm; few very fine and fine roots; many medium and coarse black manganese coatings; many continuous prominent clay films; 15 percent fine, soft yellow (10YR 7/8) siltstone fragments; gradual wavy boundary.

$\mathrm{BC}-93$ to $136 \mathrm{~cm}$ (36.5 to 53.5 inches); yellowish brown (10YR 5/6) silty clay loam; weak medium subangular blocky structure; friable; very few very fine and fine roots; many fine and medium black manganese coatings; common discontinuous distinct strong brown (7.5YR 4/6) clay films; gradual wavy boundary.

$\mathrm{CB}-136$ to $160+\mathrm{cm}(53.5$ to $63+$ inches); mixed yellowish brown (10YR 5/6) and strong brown (7.5YR 4/6) silty clay loam; weak medium platy structure; friable; very few very fine and fine roots; many fine and medium black manganese coatings; few patchy faint clay films. 


\section{C.7. Hagerstown \#3 Characterization Data}

\begin{tabular}{|c|c|c|c|c|c|c|c|c|c|}
\hline \multirow{3}{*}{ Horizon } & \multirow{3}{*}{ Depth } & \multicolumn{8}{|c|}{ Particle Size } \\
\hline & & \multicolumn{3}{|c|}{ Total } & \multicolumn{5}{|c|}{ Sand } \\
\hline & & Sand & Silt & Clay & V. Coarse & Coarse & Medium & Fine & V. Fine \\
\hline & $\mathrm{cm}$ & & & & ---0 & & & & \\
\hline Ap & $0-18$ & 15.3 & 62.6 & 22.1 & 1.6 & 1.6 & 1.6 & 2.0 & 8.5 \\
\hline $\mathrm{BE}$ & $18-32$ & 12.2 & 46.1 & 41.7 & 0.7 & 0.8 & 0.9 & 1.5 & 8.3 \\
\hline Bt1 & $32-52$ & 11.5 & 27.8 & 60.7 & 0.1 & 0.5 & $\overline{0.9}$ & 2.1 & 7.9 \\
\hline Bt2 & $52-93$ & 10.4 & 20.6 & 69.0 & 0.2 & 0.4 & 0.8 & 2.6 & 6.4 \\
\hline$B C$ & $93-136$ & 7.4 & 31.0 & 61.6 & 0.1 & 0.1 & 0.4 & 1.1 & 5.7 \\
\hline $\mathrm{CB}$ & $136-160+$ & 8.2 & 34.2 & 57.6 & 0.0 & 0.2 & 0.6 & 1.7 & 5.7 \\
\hline
\end{tabular}

\begin{tabular}{|c|c|c|c|c|c|c|c|}
\hline \multirow{3}{*}{ Horizon } & \multirow{3}{*}{ Depth } & \multicolumn{4}{|c|}{ Bulk Density } & \multirow{2}{*}{\multicolumn{2}{|c|}{ Atterberg Limits }} \\
\hline & & \multicolumn{2}{|c|}{ Oven-Dry } & \multicolumn{2}{|c|}{33 kPA Desorption } & & \\
\hline & & $\mathrm{Db}>2 \mathrm{~mm}$ & $\mathrm{Db}<2 \mathrm{~mm}$ & $\mathrm{Db}>2 \mathrm{~mm}$ & $\mathrm{Db}<2 \mathrm{~mm}$ & Liquid Limit & Plasticity Index \\
\hline & $\mathrm{cm}$ & & $g$ & $n^{-3}-\ldots$ & & & \\
\hline$A p$ & $0-18$ & 1.54 & 1.51 & 1.50 & 1.47 & 35 & 12 \\
\hline $\mathrm{BE}$ & $18-32$ & 1.67 & 1.66 & 1.56 & 1.56 & 42 & 26 \\
\hline Bt1 & $32-52$ & 1.64 & 1.63 & 1.50 & 1.49 & 61 & 40 \\
\hline Bt2 & $52-93$ & 1.54 & 1.53 & 1.40 & 1.39 & 66 & 44 \\
\hline $\mathrm{BC}$ & $93-136$ & 1.55 & 1.54 & 1.41 & 1.41 & 66 & 45 \\
\hline $\mathrm{CB}$ & 136-160+ & 1.42 & 1.42 & 1.34 & 1.33 & 62 & 39 \\
\hline
\end{tabular}

\begin{tabular}{|c|c|c|c|c|c|c|}
\hline \multirow{2}{*}{ Horizon } & \multirow{2}{*}{ Depth } & \multirow{2}{*}{$\begin{array}{c}\text { Rock } \\
\text { Fragments by } \\
\text { Wt. }\end{array}$} & \multicolumn{3}{|c|}{ Water Retention } & \multirow{2}{*}{ COLE } \\
\hline & & & $33 \mathrm{kPA}$ & $1500 \mathrm{kPA}$ & \multirow{2}{*}{$\frac{\text { WRD }}{\mathrm{cm} \mathrm{cm}^{-1}}$} & \\
\hline & $\mathrm{cm}$ & 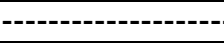 & ------ & 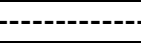 & & \\
\hline Ap & $0-18$ & 3.6 & 28.7 & 9.6 & 0.28 & 0.01 \\
\hline $\mathrm{BE}$ & $18-32$ & 0.6 & 30.6 & 15.6 & 0.23 & 0.02 \\
\hline Bt1 & $32-52$ & 0.3 & 41.7 & 23.8 & 0.24 & 0.03 \\
\hline Bt2 & $52-93$ & 0.8 & 47.3 & 26.4 & 0.25 & 0.04 \\
\hline$B C$ & $93-136$ & 0.1 & 44.6 & 23.9 & 0.29 & 0.03 \\
\hline $\mathrm{CB}$ & $136-160+$ & 0.1 & 47.0 & 24.4 & 0.30 & 0.03 \\
\hline
\end{tabular}

\begin{tabular}{|c|c|c|c|c|c|c|c|c|c|c|c|c|}
\hline \multirow{2}{*}{ Horizon } & \multirow{2}{*}{ Depth } & \multicolumn{6}{|c|}{ Extractable } & \multicolumn{2}{|c|}{ CEC } & \multirow{2}{*}{ ECEC } & \multicolumn{2}{|c|}{ Base Saturation } \\
\hline & & $\mathrm{Ca}$ & $\mathrm{Mg}$ & $\mathrm{Na}$ & $\mathrm{K}$ & Acidity & $\mathrm{Al}$ & CEC-8.2 & CEC-7 & & CEC-8.2 & CEC-7 \\
\hline & $\mathrm{cm}$ & & & & & $--\mathrm{cmol}_{\mathrm{c}}$ & $g^{-1}$ & & & & & \\
\hline$A p$ & $0-18$ & 4.9 & 1.0 & 0.3 & 0.6 & 8.7 & -- & 15.5 & 10.3 & -- & 43.9 & 66.0 \\
\hline $\mathrm{BE}$ & $18-32$ & 5.7 & 1.2 & 0.3 & 0.6 & 6.0 & -- & 13.8 & 9.7 & -- & 56.5 & 80.4 \\
\hline Bt1 & $32-52$ & 8.7 & 2.1 & 0.3 & 0.7 & 6.9 & -- & 18.7 & 13.9 & -- & 63.1 & 84.9 \\
\hline Bt2 & $52-93$ & 8.7 & 2.0 & 0.3 & 0.5 & 8.4 & -- & 19.9 & 14.4 & -- & 57.8 & 79.9 \\
\hline $\mathrm{BC}$ & $93-136$ & 5.3 & 2.2 & 0.2 & 0.3 & 10.5 & 2.6 & 18.5 & 12.5 & 10.6 & 43.2 & 64.0 \\
\hline $\mathrm{CB}$ & $136-160+$ & 3.5 & 1.9 & 0.3 & 0.2 & 12.7 & 3.8 & 18.6 & 15.2 & 9.7 & 31.7 & 38.8 \\
\hline
\end{tabular}




\begin{tabular}{|c|c|c|c|c|c|c|c|c|}
\hline \multirow{2}{*}{ Horizon } & \multirow{2}{*}{ Depth } & \multirow{2}{*}{ Al Saturation } & \multicolumn{3}{|c|}{ Total } & \multirow{2}{*}{$\begin{array}{c}\text { Extractable } \\
\mathrm{Mn}\end{array}$} & \multicolumn{2}{|c|}{$\mathrm{pH}$} \\
\hline & & & Carbon & Sulfur & Nitrogen & & 1:1 Water & $1: 2 \mathrm{CaCl}_{2}$ \\
\hline & $\mathrm{cm}$ & & $---0 \%$ & 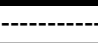 & (--9 & $\mathrm{mg} \mathrm{kg}^{-1}$ & & \\
\hline $\mathrm{Ap}$ & $0-18$ & $\overline{--}$ & 2.13 & 0.04 & 0.21 & -- & 5.6 & 5.1 \\
\hline $\mathrm{BE}$ & $18-32$ & -- & 0.47 & 0.02 & 0.06 & -- & 5.8 & 5.1 \\
\hline Bt1 & $32-52$ & -- & 0.34 & 0.03 & 0.04 & -- & 5.9 & 5.4 \\
\hline Bt2 & $52-93$ & -- & 0.26 & 0.03 & 0.07 & -- & 5.9 & 5.6 \\
\hline $\mathrm{BC}$ & $93-136$ & 24.5 & 0.14 & 0.04 & 0.03 & 4.00 & 5.0 & 4.3 \\
\hline $\mathrm{CB}$ & $136-160+$ & 39.2 & 0.14 & 0.03 & 0.07 & 5.90 & 5.1 & 4.2 \\
\hline
\end{tabular}

\begin{tabular}{|c|c|c|c|c|c|c|c|c|}
\hline \multirow{2}{*}{ Horizon } & \multirow{2}{*}{ Depth } & \multicolumn{7}{|c|}{ Total Elemental Analysis } \\
\hline & & $\mathrm{Fe}$ & $\mathrm{Mn}$ & $\overline{\mathrm{Al}}$ & $\mathrm{Ca}$ & $\mathrm{Mg}$ & $\mathrm{Na}$ & $\bar{K}$ \\
\hline & $\mathrm{cm}$ & & & & $-\mathrm{mg} \mathrm{kg}^{-1}$ & & & \\
\hline Ap & $0-18$ & 24501.1 & 1799.7 & 40169.7 & 1409.4 & 1218.8 & 1101.4 & 2433.0 \\
\hline $\mathrm{BE}$ & $18-32$ & 44855.3 & 639.2 & 64311.7 & 1243.9 & 1745.4 & 767.2 & 2723.7 \\
\hline Bt1 & $32-52$ & $\overline{56453.4}$ & 1630.1 & 89497.6 & 1573.8 & 2198.3 & 547.8 & 2289.6 \\
\hline Bt2 & $52-93$ & 58537.4 & 1562.5 & 88525.5 & 1656.7 & 1962.2 & 508.6 & 1963.0 \\
\hline $\mathrm{BC}$ & $93-136$ & 53095.0 & 950.9 & 87484.6 & 955.0 & 2071.2 & 529.7 & 2638.7 \\
\hline $\mathrm{CB}$ & $136-160+$ & 38884.6 & 997.8 & 68326.1 & 624.9 & 1713.8 & 519.7 & 2550.1 \\
\hline
\end{tabular}

\begin{tabular}{|c|c|c|c|c|c|c|c|c|}
\hline \multirow{2}{*}{ Horizon } & \multirow{2}{*}{ Depth } & \multicolumn{7}{|c|}{ Total Elemental Analysis } \\
\hline & & $P$ & $\mathrm{Si}$ & $\mathrm{Cu}$ & $\mathrm{Zn}$ & $\mathrm{Ni}$ & As & Co \\
\hline & $\mathrm{cm}$ & & & & $\mathrm{mg} \mathrm{kg}^{-1}$ & & & \\
\hline Ap & $0-18$ & 626.7 & 136823.7 & 45.7 & 131.3 & 11.4 & 21.1 & 68.0 \\
\hline $\mathrm{BE}$ & $18-32$ & 435.6 & 136729.5 & 56.4 & 129.6 & 18.9 & 8.5 & 112.9 \\
\hline Bt1 & $32-52$ & 534.3 & 130863.8 & 81.8 & 151.4 & 42.8 & 12.8 & 172.3 \\
\hline Bt2 & $52-93$ & 614.9 & 123590.2 & 85.1 & 159.7 & 51.3 & 9.3 & 171.8 \\
\hline$B C$ & $93-136$ & 603.6 & 131693.7 & 69.1 & 155.2 & 41.3 & 12.5 & 139.1 \\
\hline CB & $136-160+$ & 807.5 & 125521.9 & 72.9 & 96.4 & 29.5 & 10.1 & 192.8 \\
\hline
\end{tabular}

\begin{tabular}{|c|c|c|c|c|c|c|c|c|c|c|c|}
\hline \multirow{2}{*}{ Horizon } & \multirow{2}{*}{ Depth } & \multicolumn{10}{|c|}{ Total Elemental Analysis } \\
\hline & & $\mathrm{Se}$ & $\mathrm{Cd}$ & $\mathrm{Pb}$ & $\mathrm{Ba}$ & $\mathrm{Ag}$ & $\mathrm{Hg}$ & Mo & $\mathrm{Cr}$ & $\mathrm{Be}$ & $\mathrm{V}$ \\
\hline & $\mathrm{cm}$ & & & & & $-\mathrm{mc}$ & $\mathrm{g}^{-1}-$ & & & & \\
\hline$A p$ & $0-18$ & $\mathrm{BDL}$ & $\mathrm{BDL}$ & 34.5 & 317.5 & $\mathrm{BDL}$ & $\mathrm{BDL}$ & $\mathrm{BDL}$ & 11.0 & 2.4 & 51.8 \\
\hline $\mathrm{BE}$ & $18-32$ & 0.6 & $\mathrm{BDL}$ & 9.9 & 289.8 & BDL & BDL & $\mathrm{BDL}$ & 33.0 & 4.1 & 77.8 \\
\hline Bt1 & $32-52$ & 0.6 & $\mathrm{BDL}$ & 0.6 & 212.8 & $\mathrm{BDL}$ & $\mathrm{BDL}$ & $\mathrm{BDL}$ & 60.9 & 6.4 & 110.7 \\
\hline $\mathrm{Bt} 2$ & $52-93$ & 0.2 & $\mathrm{BDL}$ & 48.4 & 170.0 & $\mathrm{BDL}$ & $\mathrm{BDL}$ & $\mathrm{BDL}$ & 69.3 & 6.8 & 114.9 \\
\hline $\mathrm{BC}$ & $93-136$ & 0.7 & $\mathrm{BDL}$ & 25.3 & 223.5 & $\mathrm{BDL}$ & $\mathrm{BDL}$ & $\mathrm{BDL}$ & 43.2 & 5.3 & 97.2 \\
\hline $\mathrm{CB}$ & $136-160+$ & 0.5 & 1.2 & 16.4 & 212.9 & $\mathrm{BDL}$ & $\mathrm{BDL}$ & 0.5 & 39.2 & 5.5 & 96.7 \\
\hline
\end{tabular}

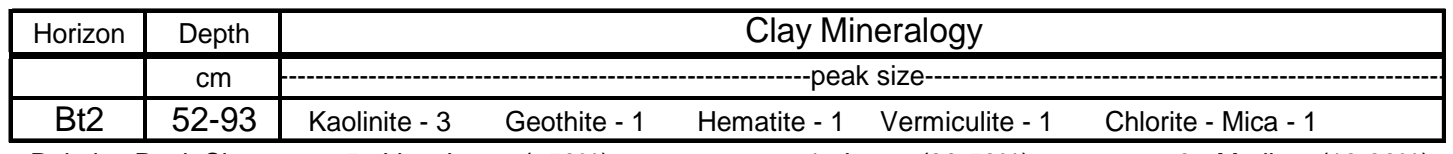

Relative Peak Size: $\quad 5$ - Very Large $(>50 \%) \quad 4$ - Large $(30-50 \%) \quad 3$ - Medium $(10-30 \%)$

$$
2 \text { - Small (3-10\%) } \quad 1 \text { - Very Small }(<3 \%)
$$

